University of Louisville

ThinkIR: The University of Louisville's Institutional Repository

Electronic Theses and Dissertations

$12-2008$

\title{
Comparative evaluation of ethanol yield from HTF corn varieties in the whisky production process.
}

Kara Marie Zoeller

University of Louisville

Follow this and additional works at: https://ir.library.louisville.edu/etd

\section{Recommended Citation}

Zoeller, Kara Marie, "Comparative evaluation of ethanol yield from HTF corn varieties in the whisky production process." (2008). Electronic Theses and Dissertations. Paper 1652.

https://doi.org/10.18297/etd/1652

This Master's Thesis is brought to you for free and open access by ThinkIR: The University of Louisville's Institutional Repository. It has been accepted for inclusion in Electronic Theses and Dissertations by an authorized administrator of ThinkIR: The University of Louisville's Institutional Repository. This title appears here courtesy of the author, who has retained all other copyrights. For more information, please contact thinkir@louisville.edu. 


\title{
COMPARATIVE EVALUATION OF ETHANOL YIELD FROM HTF CORN VARIETIES IN THE WHISKY PRODUCTION PROCESS
}

\author{
By \\ Kara Marie Zoeller \\ B.S., University of Louisville, 2008

\begin{abstract}
A Thesis
Submitted to the Faculty of the

University of Louisville

Speed School of Engineering

For the Professional Degree

MASTER OF ENGINEERING

Department of Chemical Engineering
\end{abstract} \\ As Partial Fulfillment of the Requirements
}

December 2008 


\section{COMPARATIVE EVALUATION OF ETHANOL YIELD FROM HTF CORN VARIETIES IN THE WHISKY PRODUCTION PROCESS}

Submitted by:

Kara Marie Zoeller

A Thesis Approved on

December 10, 2008

By the Following Reading and Examination Committee:

\begin{tabular}{c}
\hline Eric Berson, Thesis Director \\
\hline Martin Klotz \\
Gerold Willing
\end{tabular}




\section{ACKNOWLEDGMENTS}

Many thanks are due to Charles Geisler, the project engineer who designed and

directed this experiment. He provided much information about, and background of, the whisky production process. Thanks also to Eric Berson, the thesis advisor for this project, for guidance on technical writing and clarity. 


\begin{abstract}
In the whisky industry there is a balance between the desire to adhere to the traditional production process and the desire to increase profit margins. One solution that follows both stipulations is to increase the alcohol yield of a given batch of whisky. This can be achieved by utilizing high total fermentable corn which has a higher concentration of fermentable starches than other corn. HTF corn has the potential for a greater final ethanol yield. By simply using a higher quality of raw materials, the integrity of the process is maintained while allowing for an increase in output.
\end{abstract}

Ten strains of HTF corn (35D28, 35Y33, 34M94, 32K33, 34P88, 33A84, 34H31, 31G66, 33N56, and 34A15) and four strains of control corn (33N09, 32W86, 33M54, and 34D71) were tested for mash $\mathrm{pH}$, sugar content by mass (balling), conversion of starch to sugar, conversion of sugar to ethanol, and alcohol content by volume (ABV). Ten trials were performed using HTF corn, yielding 60 fermentations; 18 trials were performed using control corn, yielding 158 fermentations. Each trial yielded five to nine fermentations depending on the size of the cooks. Due to contamination from an unknown source, only 44 HTF and 41 control fermentations were clean and, therefore, were used to establish the most significant trends.

For a $99 \%$ confidence level, a clean HTF fermentation yielded $9.69 \% \pm 0.14 \%$ $\mathrm{ABV}$ and a clean control fermentation yielded $9.34 \% \pm 0.08 \% \mathrm{ABV}$. From these values it was determined that the HTF corn provides a 3.6\% increase in alcohol yield over 
control corn. This indicates that the HTF corn may provide an advantage over the control corn when moved to an industrial scale.

When the strains of corn were compared on an individual basis, HTF strain $32 \mathrm{~K} 22$ appeared to be the strain of choice for whisky production at this preliminary stage. Strain 32K22 provided for the highest levels of conversion of both starch and sugar, at $97.6 \%$ and $98.3 \%$ respectively, and it produced the highest alcohol content of any strain at $10.42 \% \mathrm{ABV}$. The $32 \mathrm{~K} 22$ strain achieved an overall conversion of starch to ethanol of 95.9\% which is significantly higher than the average overall conversion for the control corn, $88.5 \%$. 
TABLE OF CONTENTS

$\underline{\text { Page }}$

APPROVAL PAGE

ACKNOWLEDGEMENTS

ABSTRACT

LIST OF TABLES

LIST OF FIGURES

I. INTRODUCTION

II. BACKGROUND

1

A. Types of Liquor

B. Grain Preparation

C. Mashing

D. Fermentation

E. Distillation

F. Analysis

G. Hybrid Corn

III. EQUIPMENT AND MATERIALS

IV. PROCEDURE

V. PLAN OF EXPERIMENTATION

VI. RESULTS AND DISCUSSION

VII. CONCLUSIONS

VIII. RECOMMENDATIONS

REFERENCES CITED

APPENDIX A. SAMPLE CALCULATION OF GRAIN BILL

APPENDIX B. MILLED CORN SIZE SPECIFICATIONS

APPENDIX C. RAW DATA

APPENDIX D. CONVERSION DATA

APPENDIX E. STATISTICAL ANALYSIS

VITA iii

iv

viii

ix

ii

viii

3

3

4

5

7

9

10

11

13

19

26

28

39

41

42

43

44

45

71

72

73 


\section{LIST OF TABLES}

$\underline{\text { Page }}$

TABLE I DIVISION OF CLEAN AND CONTAMINATED COOKS 31

TABLE II STRAIN CONVERSION AND ETHANOL PRODUCTION 36

TABLE III AVERAGE VALUES OF TRIAL DATA 37

TABLE IV PRELIMINARY DATA 45

$\begin{array}{lll}\text { TABLE V } & \text { SET DATA } & 51\end{array}$

$\begin{array}{lll}\text { TABLE VI DROP DATA } & 57\end{array}$

$\begin{array}{lll}\text { TABLE VII HPLC DATA } & 63\end{array}$

$\begin{array}{lll}\text { TABLE VIII GC DATA } & 67\end{array}$

TABLE IX CONVERSION OF STARCH IN CLEAN FERMENTATIONS 71

TABLE X CONVERSION OF SUGAR IN CLEAN FERMENTATIONS 71

TABLE XI STATISTICAL ANALYSIS OF ALL FERMENTATIONS 


\section{LIST OF FIGURES}

$\underline{\text { Page }}$

FIGURE 1 - Mashing Cookers $\quad 14$

FIGURE 2 - Fermentation Bath Schematic 16

FIGURE 3 - ABV vs. Drop pH for all Fermentations 29

FIGURE 4 - Lactic Acid Content vs. Drop pH of Fermentations 30

FIGURE 5 - Conversion of Starch to Sugar by Strain 34

FIGURE 6 - Conversion of Sugar to Ethanol by Strain 35 


\section{INTRODUCTION}

The production of whisky is a practice that has been performed for hundreds of years. Because of this, there are multiple traditions and attitudes that have been culturally solidified, many of which have been carried over to the industrial scale. This traditionalist viewpoint that is prevalent in the industry can make it difficult to receive acceptance for alterations to the production process for fear of compromising the integrity of the product, especially since these improvements are typically made for the benefit of the profit margin and not the product itself. Therefore, it is vital to determine methods of enhancement that infringe as little as possible on the conventionally held sensibilities.

Between the necessities of preserving the integrity of a specific brand and the restriction of following federally regulated guidelines, the opportunities for the improvement of the production process for whisky is severely limited. Because whisky is diluted down to its saleable proof only immediately before bottling, the majority of these improvement methods have centered on the increase of the proof during the production process. For example, during recent years the whisky industry as a whole has begun to age whisky in barrels at a much higher poof than in the past, leading to a financial gain. Now, by law, whisky cannot be barreled at a proof greater than 125; this is significantly higher than was typically done, but it allows for fewer barrels and less warehouse space to be used (Alcohol and Tobacco Tax and Trade Bureau, 2008). 
Another approach to making whisky production more economical is the use of hybrid corn to enhance the amount of ethanol produced per quantity of grain. The development of corn with a supposed higher level of fermentable starch has led to the possibility of achieving a greater proof per batch of whisky mash produced. This would, in turn, lead to a greater amount of product for the same amount of grain, which is monetarily advantageous. This is a particularly desirable route because it falls in line with the traditional method perfectly as it does not alter the actual production process, it relies solely on the use of higher quality raw materials.

The objectives of this experimentation were to determine how much more ethanol can be produced per batch using a hybrid species of corn specifically engineered to have a greater amount of high total fermentable (HTF) starch rather than the non-HTF species of corn currently used and whether the increase is significant enough to justify switching corn types in production on an industrial scale. In order to accomplish this, a number of trials were run with both control corn (non-HTF species) and experimental corn (HTF hybrids). Several strains of each type were used in order to make as comprehensive a comparison as possible. Four strains of non-HTF and ten strains of HTF corn were studied. For each trial, whole corn was milled and then cooked in a mashing process. The mash was then fermented and the resulting product distilled to determine the ethanol content. A comparison of the ethanol content was made in order to establish the statistical significance of any difference. 


\section{BACKGROUND}

Distilled liquors have been produced for hundreds of years and, over that time, the process has become refined as well as highly regulated. Because of this, there are limited routes to advancement in the field that fall within the government guidelines while simultaneously following the traditional means of production that have become standard. In 2007 over six billion gallons of ethanol was generated, consuming $27 \%$ of the U.S. corn harvest (Pioneer, 2008).

\section{A. Types of Liquor}

Distilled liquors are differentiated on the basis of the raw materials used in their preparation. Alcoholic liquids, sugary substances, and starchy substances are the broad categories that are used to produce potable beverages. Of particular interest are starchy substances which include all types of cereals, including barley, barley-malt, corn, rye, oats, etc. as well as potatoes. Whisky is only one type of alcohol that can be made from these starchy substances and can, in fact, be delineated further on the basis of its grain bill. This term refers to the ratio of cereals that are used as raw materials. Different types of whiskies include bourbon whisky, rye whisky, malt whisky, and wheat whisky. Bourbon whisky, the most commonly produced variety, is separated into three distinct classes. Ordinary bourbon whisky is derived from a grain bill of $10 \%$ barley-malt, $10 \%$ rye, and $80 \%$ corn. In contrast, medium bourbon whisky is $12 \%$ barley-malt, $18-22 \%$ 
rye, and $66-70 \%$ corn while good bourbon whisky is $15 \%$ barley-malt, $35 \%$ rye, and $50 \%$ corn (The Encyclopedia Americana, 1918).

The process for the production of whisky and other distilled liquors has been refined over hundreds of years to the highly regimented practice that is in use today. This constraint of the method allows not only for a more consistent product, but also for the ability to regulate the quality of product placed in the market.

\section{B. Grain Preparation}

The preparation of grain has long-reaching effects on the quality of liquor that is produced. Predominant among these preparatory steps is the proper method of malting the grain, typically barley. Malting is the process by which grain is soaked in water, allowing it to partially germinate and produce enzymes. This malted grain is the natural source of the enzymes that degrade starches into fermentable sugars. While malted barley is most commonly used, rye and wheat can also be malted. Distiller's malt is meant to achieve a maximum diastatic power, or enzymatic power, as opposed to brewer's malt which must also impart flavor to the resultant beer. Before the grain can sprout, it is slowly dried at low temperatures to preserve the enzymatic abilities at peak concentration. Distillers prefer "long malt" which is dried over a period of 20 days which, while leading to a decrease of starch in the grain, yields a significantly greater diastatic power. In contrast, brewers prefer "short malt" which is dried for 7 days and retains much more of its inherent starch content. Additionally, malt used by distillers typically has a greater content of nitrogenous matter as this allows for the production of 
more enzymes as well as providing supplementary sustenance for the yeast during fermentation (The Encyclopedia Americana, 1918).

There are a variety of methods by which grains can be milled including roller milling, impact milling, and wet milling. The first two types fall under the category of "dry milling," meaning the ground grain, or grist, is fed into a hopper or other receiving container rather than directly into the mashing tun where it is mixed with water as is the case in wet milling (Brewing: Science and Practice, 2004). Dry milling is predominantly used in industry, with $86 \%$ of ethanol produced in the U.S. in 2007 done so via dry milling (Pioneer, 2008). The performance of a dry mill can easily be calibrated and refined using sieve analysis. A sample of grist is loaded onto the top of a vertical stack of sieves with increasingly small pore sizes and shaken mechanically for a period of time. The percentage by weight of the grist on each sieve can be compared to ensure that the mill is operating properly and producing milled grain that falls within specifications (Brewing: Science and Practice, 2004).

The composition of the grain, such as starch and water, is dependent on the type and variety of grain as well as its handling. For corn, its moisture content is also affected by the season during which it is harvested and the humidity of the air.

\section{Mashing}

The actual process for the production of whisky can be broken down into roughly three steps: mashing, fermentation, and distillation. Mashing is the means by which the starch in the grains is converted into the fermentable sugar maltose. In the case of ordinary bourbon whisky, the corn component of the grain bill will provide the vast 
majority of the starch necessary. This process begins with the milled corn being mixed with hot water and then boiled to induce gelatinization (The Encyclopedia Americana, 1918). In some instances, an amount of malt is added to the corn in order to reduce the viscosity of the mash, which dramatically increases as the gelatinization takes place (The Biotechnology of Malting and Brewing, 1991).

The combination of heat and water breaks down the intermolecular bonds of the starch molecules, exposing the hydrogen bonding sites and allowing the penetration of water. If the starch is not properly gelatinized, the enzymes cannot further degrade the starch into sugar. There are two types of starch found in grains: amylose and amylopectin. Amylose is a glucose polymer that contains 1,000-4,000 glucose units. Each unit is connected via an $\alpha 1,4$ bond creating a long, single chain. Amylose has only one functional reducing group which is located at the end of the molecule. Amylopectin is typically a larger glucose polymer that consists of over 250,000 units of glucose. While most of the units are connected with $\alpha 1,4$ bonds, some units are linked by $\alpha 1,6$ bonds which result in a branching chain. Although amylopectin tends to be degraded preferentially to amylose, it also only possesses one functional reducing group (The Biotechnology of Malting and Brewing, 1991).

Once the corn mash has been gelatinized, it is cooled to 156 to $160^{\circ} \mathrm{F}$ and any non-malted cereals are added. The mash is then further cooled to $150^{\circ} \mathrm{F}$ and the malt is added. In order to achieve full saccharification, the conversion of starch to sugar, the mash is held at this temperature for at least 30 minutes (The Encyclopedia Americana, 1918). This conversion is accomplished by the enzymes present in the malt added to the mash. At these temperatures, the only two enzymes that actively participate in the 
degradation of the starch are $\alpha$-amylase and $\beta$-amylase. $\alpha$-amylase is the more thermostable of the two and also performs most effectively at a more acidic environment with a $\mathrm{pH}$ of 5.3 as opposed to the optimal $\mathrm{pH}$ of 5.7 for $\beta$-amylase (The Biotechnology of Malting and Brewing, 1991). It is imperative that the malt not be added to the mash before it has cooled to the required temperature as the amylase enzymes are heat labile and will lose all catalytic ability if they become denatured. However, it is of note that both $\alpha$ and $\beta$-amylase do maintain some enzymatic activity when raised above their denaturation temperature until the enzyme is fully denatured (Brew Your Own, 2008). Theoretically, $96 \%$ of the starch in the grains can be converted into maltose, while the remaining $4 \%$ is converted into dextrin. Once the maltose has all been converted, the dextrin will then gradually be converted into maltose (The Encyclopedia Americana, 1918).

At the completion of the saccharification process, the mash is cooled to below $70^{\circ} \mathrm{F}$ and is then prepared to be moved to the fermenters. In industry, the mash is diluted with either water or slop, which is strained spent mash from a previous fermentation, to decrease the viscosity of the mash and produce sweet mash or sour mash, respectively. The sour mash is so named because the lactic acid, which can be a by-product of fermentation, in the slop lends a distinctively sour flavor to the finished product (The Encyclopedia Americana, 1918).

\section{Fermentation}

Once the mashing step has been completed, the next phase of whisky production is fermentation. Fermentation is the process by which the maltose produced during 
mashing is converted by yeast into ethanol. Contamination of the mash by bacteria can result in the conversion of glucose to lactic acid, resulting in an overly sour product. Carbon dioxide is a by-product of both the desired and undesired reactions (Geisler, 2006).

Four species of yeast that are used in the production of potable ethanol on the industrial level are Saccharomyces cerevisiae, Saccharomyces uvarum, Schizosaccharomyces pombe, and Kluyveromyces sp (Najafpour, 2002). Saccharomyces cerevisiae is the yeast type that is predominantly used in the production of whisky (The Encyclopedia Americana, 1918). Established brands of distilled liquor typically have a proprietary strain of a particular species that is carefully cultivated in order to maintain a consistent product (Geisler, 2006). Yeast operates under anaerobic conditions, utilizing the enzyme maltase to degrade maltose into glucose and then converting the glucose into ethanol via the Embden-Meyerhof pathway. This glycolysis reaction produces two molecules of ethanol per molecule of glucose; however, because some nutrients are required for the maintenance of the yeast cells, in actual fermentations the yield typically does not exceed $90 \%$ of the theoretical (Najafpour, 2002). The chemical reactions of the degradation of maltose and glucose, respectively, are illustrated below:

$$
\begin{gathered}
\mathrm{C}_{12} \mathrm{H}_{22} \mathrm{O}_{11} \rightarrow 4 \mathrm{CO}_{2}+4 \mathrm{C}_{2} \mathrm{H}_{5} \mathrm{OH} \\
\mathrm{C}_{6} \mathrm{H}_{12} \mathrm{O}_{6} \rightarrow 2 \mathrm{CO}_{2}+2 \mathrm{C}_{2} \mathrm{H}_{5} \mathrm{OH}
\end{gathered}
$$

Yeast are relatively delicate organisms so care must be taken in order to keep them alive so that total fermentation may be achieved. Due to the large amount of carbon dioxide that is produced as a by-product, the vessels in which fermentation is carried out must have some method of gas release because the increasing pressure caused by the 
generation of carbon dioxide could be great enough to destroy the yeast cells. In industry, fermentation is frequently carried out in open vessels in order to avoid this complication in spite of the increased risk of contamination. Like many other organisms, yeast is vulnerable to ethanol inhibition. Once the alcohol content of the fermenting mash has reached $15 \%$ by volume, the growth rate of the yeast will halt completely, ending the fermentation regardless of the amount of remaining glucose (Geisler, 2006).

In an industrial setting, once a yeast mash has thoroughly propagated, 10 to 14 hours after addition, it is then added to the grain mash. The greatest amount of fermentation activity takes place 24 hours after the yeast has been added to the mash and continues for 12 to 18 hours. It is important that during fermentation the mash maintains a temperature below $85^{\circ} \mathrm{F}$ both to prevent the alcohol generated from evaporating as well as maintaining an optimal operating temperature for the yeast. Sweet mash whiskies are typically fermented for 72 hours while sour mash whiskies require 76 hours (The Encyclopedia Americana, 1918).

\section{E. Distillation}

The final step in creating raw distilled spirits is the distillation of the fermented, or sour, mash. Distillation is the simple mechanical separation of substances based on their differing boiling points; water boils at $212^{\circ} \mathrm{F}$ while ethanol boils at $173.5^{\circ} \mathrm{F}$. The distillation apparatus is comprised of a still, a condenser, and a receiver. With the best equipment, a highly concentrated alcoholic liquid of 192 proof, or $96 \%$ alcohol by volume, can be obtained. This is the highest concentration possible to achieve because at this composition ethanol and water form an azeotrope, making further purification via 
distillation infeasible. However, this is a much higher concentration than is needed in the potable beverage industry (The Encyclopedia Americana, 1918). Because distilled liquors are sold at a designated proof, fluctuations in ethanol content among batch fermentations do not adversely affect the final product. However, a greater ethanol content in the sour mash would result in an increase in saleable product once the resulting distillate is diluted, or cut, to its specified proof (Geisler, 2006).

\section{F. Analysis}

There are a variety of analysis methods that can be used to determine the degree of success of a given ethanol production trial, among these are near infra-red (NIR) spectroscopy, high performance liquid chromatography (HPLC), and standard gas chromatography (GC).

NIR can be used to analyze a range of grain types for a variety of properties. In particular, corn can be evaluated to determine levels of proteins, oils, moisture, and starch. While protein and oil content is of greater importance when establishing suitability of feedstock, verifying the moisture content as well as the starch content has profound importance in the production of alcohol. The level of moisture in corn dictates the handling and storage needs of the grain in addition to influencing the weight of the grain to such a degree that the calculation of grain bills could be impacted. NIR analysis can also be used to indicate the level of extractable starches present in the corn. This is presented with regards to fermentation as potential grams of carbon dioxide lost per 100 grams of corn (FOSS, 2008). 
As an analysis technique, HPLC is advantageous for several reasons. It can be performed rapidly, has a high precision, and the required sample preparation is very simple. HPLC can be used to determine the content of sugars, organic and amino acids, glycerol, and a variety of alcohols of a liquid. In industry this is particularly beneficial as the presence of some substances may indicate an undesired process taking place during fermentation, possibly signifying contamination of the mash. HPLC is also invaluable in the arena of quality control (Nollet, 2000).

Standard GC analysis is particularly well suited to the analysis of alcohols in distilled liquor because they are thermostable, volatile substances. Gas chromatography operates by volatizing compounds in a liquid sample which then separate and can be quantified as they pass through a stationary column. This quantification is carried out with respect to an internal standard of the specific analysis apparatus used, typically benzyl alcohol, 3-pentanol, or n-butyl alcohol. GC is most commonly used for the detection of higher alcohols, such as n-propyl alcohol, isobutyl alcohol and isoamyl alcohol, which are collectively known as fusel oils. These alcohols have a considerable impact on the flavor profiles of the finished product, and in the U.S. and some other countries they have federally regulated allowable concentrations (Nielsen, 2003).

\section{G. Hybrid Corn}

In the alcohol production process, the amount of starch available in the grain, particularly the corn, is a dominant limiting factor. Because of this, agricultural companies have endeavored to develop hybrids of corn that contain greater levels of fermentable starches, denoted as high total fermentable (HTF) hybrids. Based on the dry 
grind ethanol yield potential, the company Pioneer claims a 2-4\% ethanol yield gain for any of its $182 \mathrm{HTF}$ corn hybrids as compared to non-HTF species. Pioneer asserts that each per cent increase in ethanol yield is worth $\$ 0.05$ per bushel of corn, leading to an increase of $\$ 1.2-\$ 2.3$ billion per year of the value of corn by the year 2010 (Pioneer, 2008). This increased ethanol yield potential of the hybrid corn creates an opportunity for large distilleries to decrease their overall cost should the increased yield be significant enough to offset the greater cost of hybrid corn (Geisler, 2006). 


\section{EQUIPMENT AND MATERIALS}

The required equipment and instrumentation are described in order of the step in the process in which they are used: preparation, mashing, fermentation, distillation and analysis.

The preparation stage includes not only the preliminary sterilization that is necessary to reduce the possibility of contamination, but also the initial analysis of the corn and the milling of the grain. An autoclave (Alfa Medical, Westbury, NY) is used to sterilize the materials that come in contact with the mash via extreme temperature and pressure. This includes the yeast media and the graduated cylinder used to measure it, as well as the containers the mash is fermented in. The excess yeast not needed for backculturing at the end of each cook are killed in the autoclave before disposal.

The unmilled corn is analyzed for percent moisture and potential grams of $\mathrm{CO}_{2}$ loss per 100 gram of corn using a near infra-red (NIR) spectrometer (FOSS, Ashland, VA) with a wavelength range of 570-1100 nm. The percent moisture indicates the proper storage of the corn as well as influencing the weight of the corn when used in later calculations. The grams of $\mathrm{CO}_{2}$ loss per 100 grams of corn is indicative of the amount of fermentable starch present in the grain (Foss, 2008). The grain is milled in a lab-scale impact hammer mill (Raymond Mills, Zhengzhou, China). Swing hammers in the mill crush the grain as it is fed into the grinder. Once the corn has been milled, a sample is shaken through a series of sieve screens (H\&C Sieving Systems, Columbia, MD) in order to ensure that the grain has been milled to a proper degree. Six screens are used to 
differentiate the array of grist sizes produced by the mill. The brass frame-stainless steel cloth sieves used are U.S. Standard \#10, \#20, \#40, \#80 and \#100 having pore sizes of 2.0 $\mathrm{mm}, 1.7 \mathrm{~mm}, 425 \mu \mathrm{m}, 180 \mu \mathrm{m}$ and $150 \mu \mathrm{m}$ respectively. Any grist passing through all screens is denoted as flour and is collected in a flour pan at the bottom of the stack of sieve screens (H\&C Sieving Systems, 2008).

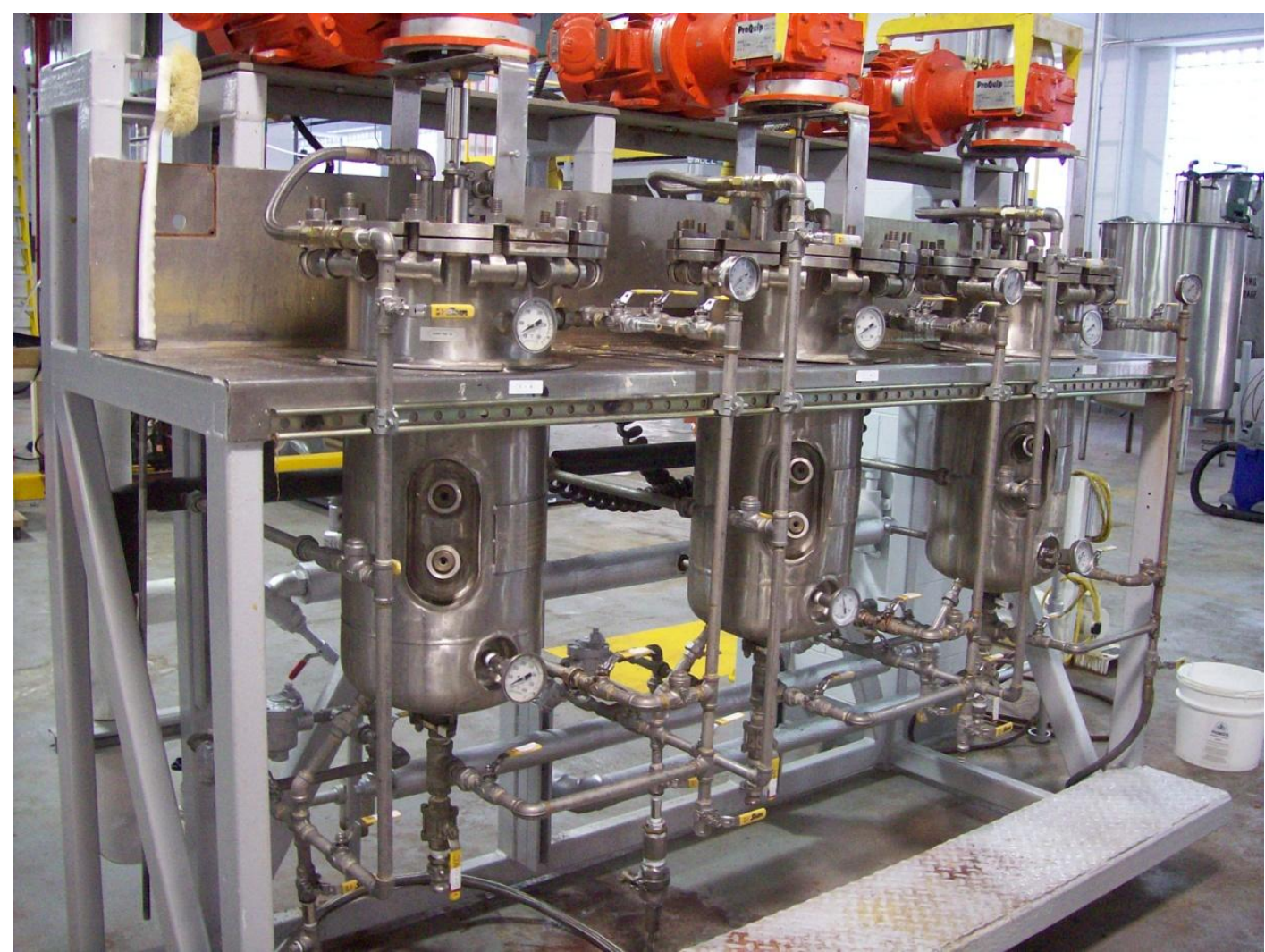

FIGURE 1 - Mashing Cookers. Mashes are cooked in 40 L steam-jacketed cookers.

The mashing process is carried out in three $40 \mathrm{~L}$ capacity agitated, jacketed kettle cookers, shown in FIGURE 1 (Roark Enterprises, Louisville, KY). These cookers were differentiated with the designations \#9, \#10, and \#11 from left to right. The jacket of each stainless steel cooker is connected to both steam and water lines while the interior of the cooker is only directly piped for water. When heating, the water to the jacket is shut off and the steam line is open. The temperature of the mash is regulated by throttling the 
steam valve. If not properly controlled, the mash can boil and overflow out of the cooker. When cooling, water flows through a jacket that surrounds the tank. Agitation in the cooker is achieved by means of a triple bladed impeller that is submerged vertically into the mash. The mash must be well-mixed in order to eliminate hot spots and prevent scorching. Before dropping the mash at the end of a cook, the drain valve of the kettle is steamed for ten minutes to ensure sterilization.

The individual fermentations, three per cooker, are carried out by placing $3 \mathrm{~L}$ of mash and yeast in a 4 L Nalgene container with a screw-on lid (Thermo Fisher Scientific, Rochester, NY). The containers are translucent plastic so that the level of mash can be easily ascertained. During the fermentation, the lids of the Nalgenes are screwed on only slightly so that the carbon dioxide produced by the yeast can escape the container to avoid a build-up of pressure within that could damage or kill the yeast. The Nalgenes are placed in a fermentation bath so that the temperature of the mash can be regulated and kept at the optimum operating temperature of the yeast.

The temperature of the fermentation baths are controlled via a chiller bath and circulator, specifically, a NesLab RTE-111, as seen in FIGURE 2 (Thermo NesLab, Oak Park, IL). Each bath is large enough to fit nine $4 \mathrm{~L}$ Nalgenes and is filled so that the water level in the bath is just above that of the mash in the containers. The chiller is filled with a 50-50 water-glycol mixture which is circulated through copper coils submerged in the bath. Each chiller is controlled using its companion software program. This software can be programmed so that a specific regiment of temperatures and durations is carried out automatically. It also tracks the actual temperature of the water bath in graphical form along with the target temperature. 


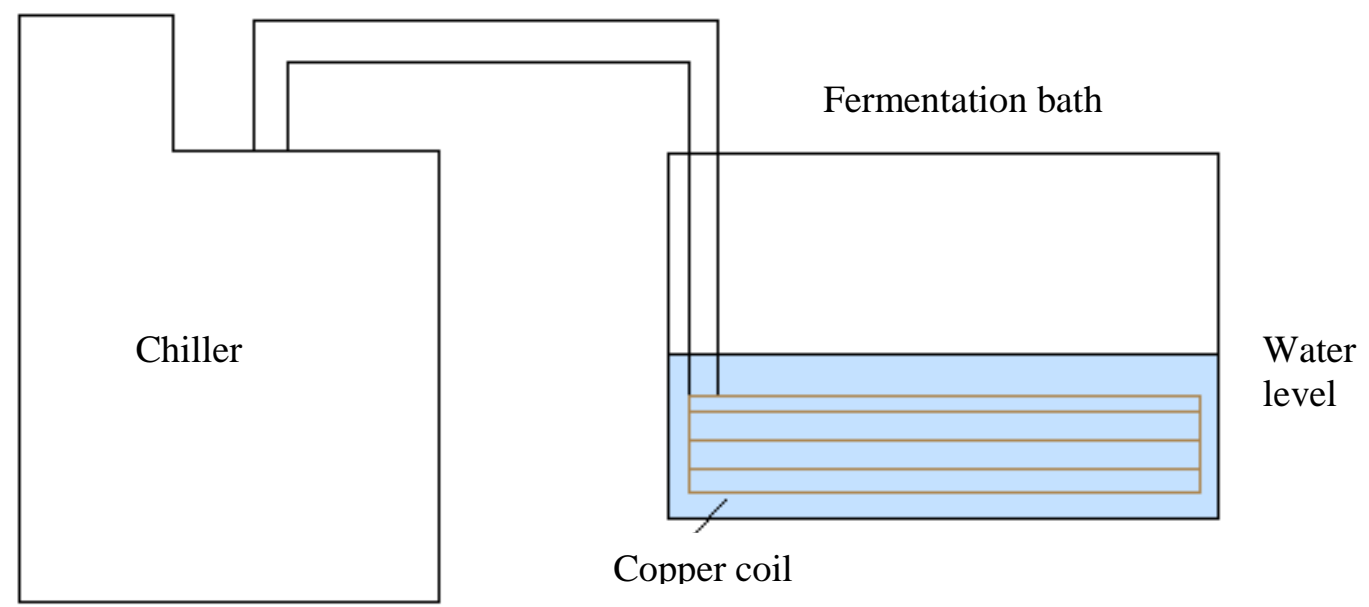

FIGURE 2 - Fermentation Bath Schematic

The mash is analyzed for a variety of properties. A hydrometer with thermometer for temperature adjustment (VWR Scientific, West Chester, PA) is used to determine the balling, or sugar content, of the mash both before and after fermentation. A comparison of the two values allows for an estimation of conversion. $\mathrm{A} \mathrm{pH}$ meter (Techne, Burlington, NJ) was also used to analyze the mash pre- and post-fermentation. These values provided an indication of contamination as an increased presence of lactic acid signifies the existence of undesirable bacteria. The fermented mash is inspected via a high performance liquid chromatography (HPLC) machine (Waters, Milford, MA) for the concentration of acids, such as citric, succinic, lactic, and acetic, as well as sugars, including maltose, glucose, and fructose. HPLC can also be used to determine the ethanol content of the mash.

The analytical distillation is performed using Kjeldahl flasks (Kontes, Vineland, NJ) and burners (Precision Scientific, Arlington Heights, IL). As a 50/50 water-diluted mash sample is boiled in the bottom of the flask, the vapor travels through an upward 
sloping glass gooseneck tube to the vertical condenser column. The condenser is kept cool by a 50/50 glycol-water mixture that is chilled using the same sort of thermal bath as used in the fermentation set up. The distillate is collected in a volumetric flask until half the sample volume has been acquired.

The distillate obtained is also analyzed. Using a density meter (Anton Paar, Ashland, VA), the ethanol content, or percent alcohol by volume (ABV), can be determined. A more in-depth analysis of the distillate can be achieved through the use of a gas chromatography (GC) machine (Agilent Technologies, Santa Clara, CA). This method can breakdown the alcohol content of the sample, differentiating between methanol, n-propyl alcohol, isobutyl alcohol, and isoamyl alcohol, as well as indicating the concentration of substances such as acetaldehyde and ethyl acetate.

The materials used in this project are of vast importance as the basic goal of this project is the selection of the superior type of corn to use in the production of whisky. The corn used in the trials can be separated into two main categories: control and experimental. The control corn is comprised of non-HTF species and four distinct strains were utilized. The strain designated as 33N09 was grown in Newman, Illinois, strains 32W86 and 33M54 were grown in Toney, Alabama, and the strain 34D71 was grown in Mauzy, Indiana.

Ten strains of experimental HTF corn were used in the trials: 35D28, 35Y33, 34M94, 32K22, 34P88, 33A84, 34H31, 31G66, 33N56, and 34A15. All of the experimental corns were obtained in $10 \mathrm{lb}$ samples from the Pioneer Research \& Development Department. The malt and rye used in the mash cooks were obtained weekly from Froedtert grain suppliers to ensure freshness. 
The species of yeast used in the fermentation process was Saccharomyces cerevisiae. The media used for storage, backculture, and inoculation was $1 / 2$ malt made from Sigma-Aldrich M6409 Malt Extract Broth (St. Louis, MO).

When the analysis of a mash sample required the dilution of the mash sample, water stripped of its ions via reverse osmosis (RO water) was used in order to maintain the integrity of the sample. 


\section{PROCEDURE}

I. Yeast Media Preparation (1/2 Malt)

1. Calculate the amount of $1 / 2$ malt needed for one week's worth of cooks, including back cultures. Approximately $500 \mathrm{~mL}$ of $1 / 2$ malt is needed per cooker; $250 \mathrm{~mL}$ is needed for every back culture. Use $1 \mathrm{~L}$ screw-cap flasks for the $500 \mathrm{~mL}$ portions and $500 \mathrm{~mL}$ flasks with metal caps for the $250 \mathrm{~mL}$ portions.

2. Sigma-Aldrich M6409 Malt Extract Broth is used to create the $1 / 2$ malt. $15 \mathrm{~g}$ of dry powder media is needed per liter of water.

3. Add half of the total amount of water to a flask with a stir bar, then the powder, then the remainder of the water.

4. Bring the $1 / 2$ malt to a boil using a stirring hot plate and then separate into the individual flasks. Place autoclave tape on flasks and label and date.

5. With caps on loosely, autoclave flasks to sterilize the $1 / 2$ malt.

6. Place cooled, sterilized $1 / 2$ malt in media cabinet.

II. Autoclave Nalgenes

1. Place clean 4 L Nalgene containers with caps on loosely in autoclave and sterilize. Three Nalgenes are needed per cooker.

2. An autoclaved $250 \mathrm{~mL}$ graduated cylinder will also be needed for each cook. Once sterilized, the dry cylinder should be covered with aluminum foil to prevent contamination.

III. Yeast Scale-up 
1. Two days before the cook, transfer approximately $50 \mathrm{~mL}$ of media inoculated with Saccharomyces cerevisiae yeast to each $1 \mathrm{~L}$ flask. Label all flasks with dates of transfers.

2. Place flasks with yeast in incubator.

IV. Back culture

1. To keep the yeast strain alive, back culture every three or four days into a 500 $\mathrm{mL}$ flask of $1 / 2$ malt unless a scale-up has been performed.

\section{Grain Preparation}

1. The grain bill is $80 \%$ corn, $8 \%$ rye and $12 \%$ malt, with $10 \%$ of the malt being used as pre-malt.

2. Cooks using experimental corn use two cookers at a time and are based on the amount of milled corn available. Cooks using control corn use three cookers and are $25 \mathrm{~L}$ cooks.

3. Calculate the amount of corn, malt, rye and water needed to carry out the cook. (Sample calculation of grain bill is in Appendix A.)

4. Malt and rye, either milled or unmilled, will be collected weekly to ensure freshness. Unmilled corn, both control and experimental, will be provided by Pioneer and will be milled in the hammer mill on the day of mashing.

5. Before milling the corn, analyze the whole kernels for potential $\mathrm{CO}_{2}$ loss and percent moisture using the Foss NIR machine. Run the analysis three times and record the average.

6. To operate the hammer mill, wearing eye and ear protection, first turn on the grain grinder and then the grain feeder. Place a bucket under the mill to collect the 
grain and pour the corn in the top of the mill. Ensure that the ground corn does not back up into the mill.

7. A sieve screening will be performed on $100 \mathrm{~g}$ of the milled corn to ensure it falls within the size specifications. Place each screen on sieve shaker and shake for 20 minutes. (Sieve specifications in Appendix B.)

VI. Mashing Procedure

1. Cooks will be performed in $40 \mathrm{~L}$ agitated, jacketed cookers. Drain jackets of residual water prior to using to prevent building up large amounts of pressure when heating.

2. Immediately prior to cooking, fill the cookers approximately half way with water and boil, with the agitators on, for 10 minutes to sterilize the cookers. Drain cookers after water has slightly cooled.

3. Turn on hose and allow water to run for 10-15 minutes to avoid using previously stagnant water in cooks.

4. Collect amount of water previously calculated that is needed for each cooker and pour into each cooker.

5. Heat water to $140^{\circ} \mathrm{F}$ and add pre-malt with approximately $20 \mathrm{~g}$ of corn.

6. Heat water to $150^{\circ} \mathrm{F}$ and add remainder of corn.

7. Heat to boiling and hold for 20 minutes.

8. Cool mash to $180^{\circ} \mathrm{F}$, add rye and hold for 15 minutes.

9. Cool to $170^{\circ} \mathrm{F}$, add post-malt and hold for 10 minutes.

10. Cool to $85^{\circ} \mathrm{F}$.

11. Record the weights of all the Nalgenes that will be used. 
12. Perform a sterile yeast transfer into the Nalgenes.

a. In a sterile lab, place an autoclaved graduated cylinder, an autoclaved Nalgene and the prepared yeast in a fume hood. Ignite a small gas burner outside of the hood.

b. Yeast is added in a 5\% volume to volume ratio. Therefore, for the $3 \mathrm{~L}$ fermentations, approximately $150 \mathrm{~mL}$ of yeast should be placed in each Nalgene.

c. Remove the foil from the cylinder while keeping it in the hood. Swirl the flask to suspend the yeast and remove the cap, placing it upside down in the hood.

d. Flame the lip of the flask to sterilize it.

e. Fill the cylinder with $150 \mathrm{~mL}$ of yeast without letting the flask and the cylinder touch, and immediately flame the lip of the flask, place it back in the hood and place the lid back on.

f. Take the lid off the Nalgene, placing it upside down in the hood. Without allowing the cylinder and the Nalgene to touch, pour the yeast into the container.

g. Screw the lid back onto the Nalgene and remove from the hood.

h. Repeat until all of the Nalgenes contain yeast.

i. Turn off burner and fume blower.

j. Remove the extra yeast from the hood and return to incubator. If more than one flask remains, only one needs to be placed back in the incubator. The others may be wasted in the autoclave. 
k. Remove the graduated cylinder from the hood and rinse with water. Cover with fresh foil and a strip of autoclave tape and place on rack to be autoclaved.

1. Clean hood and counter using isopropanol.

13. Record the weight of the Nalgenes with yeast.

14. Steam the bottom of the cookers for 15 minutes to sterilize.

15. Drain approximately $2 \mathrm{~L}$ of mash into a graduated 5 gallon bucket.

16. Collect a $500 \mathrm{~mL}$ sample of set mash for analysis.

17. Collect three $3 \mathrm{~L}$ samples in the prepared Nalgenes from each cooker.

18. Drain the remainder of the mash into the graduated bucket and record the volume.

19. Record the weights of the filled Nalgenes.

VII. Fermentation Bath

1. A water bath powered by a NesLab RTE-111 Bath is used to regulate temperature during fermentation. Fill the bath so that the mash in the Nalgenes are just below the water level.

2. Place baskets containing three Nalgenes with loosened lids each in the bath to prevent them from tipping over.

3. The five day fermentation consists of an increase in temperature from an initial $70^{\circ} \mathrm{F}$ to $84^{\circ} \mathrm{F}$ over a period of 72 hours, followed by a hold of $84^{\circ} \mathrm{F}$ for 24 hours, ending with a cooling to $78^{\circ} \mathrm{F}$ for 24 hours.

4. To initiate the program controlling the bath, open the desktop icon for NesLab. Set the appropriate program parameters and click "Start." 
5. Under View, select Chart. For the Parameter 2, select "Temperature 2" and begin chart. On the chart, click on the "Log File" button. Name the log file the using the date and click OK.

VIII. Set Analysis

1. Using the $500 \mathrm{~mL}$ sample taken from each cooker, determine the $\mathrm{pH}$ of the mash.

2. Strain the mash and determine the balling using a 2:1 ratio of water to mash. Mix $90 \mathrm{~mL}$ of strained mash in a $250 \mathrm{~mL}$ graduated cylinder with $180 \mathrm{~mL}$ RO water. Find the temperature adjusted balling of the mixture, and multiply that value by three to determine the actual balling of the mash.

3. Calculate the actual cook size by converting the gallons of mash in the graduated buckets to liters and adding to it approximately 9.5 liters.

IX. Cleaning

1. To clean the cookers, fill with water then drain to remove the largest portion of the residual mash.

2. Fill the cookers again and heat to $150^{\circ} \mathrm{F}$. Add approximately $500 \mathrm{~mL}$ of $50 \%$ $\mathrm{NaOH}$ and allow to sit for 45 minutes.

3. Drain the cookers and fill with water to rinse. Drain again.

4. Fill the cookers approximately half way and bring to a boil.

5. Allow the water to cool and drain.

6. Remove the temperature gauges and plugs in the cookers to clean.

7. Wrap the gauges and plugs with Teflon tape and replace.

8. Rinse the cookers with water to remove any solids that may have fallen into the cooker. 
9. Dispose of the remaining mash and wash the buckets.

\section{Distillation}

1. Once the five day fermentation is complete, remove the Nalgenes from the bath, dry them off and record their weights.

2. Tighten the lids and shake well before the distillation process.

3. Obtain a $500 \mathrm{~mL}$ sample and determine the drop $\mathrm{pH}$ and drop balling in the same manner that the set $\mathrm{pH}$ and balling were determined.

4. Place $30 \mathrm{~mL}$ of the strained mash into an HPLC vial containing $5 \mathrm{~mL}$ of $3 \mathrm{M}$ $\mathrm{H}_{2} \mathrm{SO}_{4}$, cap, label and shake well to halt any residual fermentation activity.

5. Using volumetric $100 \mathrm{~mL}$ flasks, obtain exactly $100 \mathrm{~mL}$ of mash and pour into a $500 \mathrm{~mL}$ Kjeldahl distillation flask. Using the same volumetric flask, obtain 100 $\mathrm{mL}$ of water and add it to the distillation flask.

6. Place the distillation flask on the burner and set the power to 50, placing the same volumetric flask underneath the condensation column.

7. Allow the distillation to continue until the volumetric flask is exactly full.

8. Once full, remove from under the column and remove the flask from heat.

9. Fill the GC vial to the $1.5 \mathrm{~mL}$ mark and cap and label.

10. Use the DMA to determine the alcohol by volume (ABV) of the distilled sample.

11. Send prepared HPLC and GC vials to an Analytical lab to be analyzed.

12. Once all analyses have been completed, dispose of the mash.

13. Wash the Nalgenes. 


\section{PLAN OF EXPERIMENTATION}

Overall for this project, 28 trials, or cooks, were performed. Of these, 18 were done with control corn and yielded 158 fermentations; 10 were done with HTF experimental corn and yielded 60 fermentations. Only one strain was used for any particular trial. The HTF strains tested were 35D28, 35Y33, 34M94, 32K22, 34P88, 33A84, 34H31, 31G66, 33N54, and 34A15. All of these strains were developed by Pioneer. The control strains used were 33N09, 32W86, 33M54, and 34D71.

Initially, the whole corn used for a trial was analyzed for moisture content and maximum potential grams of $\mathrm{CO}_{2}$ loss per 100 grams of corn. This measure of $\mathrm{CO}_{2}$ loss is an indication of the fermentable starch content of the corn. The corn was then milled and a sample was analyzed using the sieve screens to determine whether the grist size fell within specifications.

The milled corn was cooked in $40 \mathrm{~L}$ jacketed cookers. At the completion of the cook, three $3 \mathrm{~L}$ samples of mash were collected in sterile Nalgene containers and inoculated with Saccharomyces cerevisiae yeast in a 5\% volume to volume ratio. The inoculated mashes were placed in the water bath and the 5 day fermentation was begun. This is known as the set point. Samples of the mash remaining in each cooker, not inoculated with yeast, were collected and analyzed for $\mathrm{pH}$ and sugar content. The term "balling" is used to denote sugar content by mass. These measurements are the set data obtained for the fermentations.

At the end of the 5 day period, the fermentation process was stopped by removing the containers from the water bath. This is the drop point. A sample of the mash from 
each fermentation was analyzed for $\mathrm{pH}$ and balling as well as by HPLC. Two samples were taken from each fermentation and were distilled; these samples were analyzed using the DMA to determine alcohol content as well as by GC. 


\section{RESULTS \& DISCUSSION}

A total of twenty-eight mash cooks were performed, with 18 being control and 10 experimental, resulting in 158 and 60 fermentations respectively. When examined as a whole, the corn used in all trials was measured on the FOSS NIR spectrometer as having a potential $38.5 \mathrm{~g}$ of $\mathrm{CO}_{2}$ loss per $100 \mathrm{~g}$ of corn at $100 \%$ conversion of starch and a moisture content of $13.1 \%$. The balling decreased over the course of the fermentation from an average of $18.4 \%$ by mass at the set point to $1.0 \%$ when completed, or dropped. The overall average $\mathrm{pH}$ decreased from 5.93 to 4.29 from set to drop. The overall average alcohol by volume (ABV) achieved for all fermentations was $9.24 \%$.

The GC analysis performed on the trials provided measurements of the amounts of various alcohols other than ethanol present in the distillate. These alcohols are collectively titled as fusel oils and, while closely monitored in an industrial setting, on an experimental scale are merely indicative of the integrity of the overall process. These other alcohols are present as the result of contamination of the mash by wild yeast or bacteria that produce other types of alcohols. The GC analysis was performed on the first 22 trials and indicated only trace amounts of fusel oils were present. It was, therefore, deemed unnecessary to carry out the analysis on the remaining trials. The data obtained by the GC analysis can be found in Appendix C.

Through the course of the project it was observed that a number of the cooks

(trials $3,6,7,8,9,13,14,15,16,18,20,21,22,23$, and 24) showed signs of contamination. Of these, only trials 3,14 , and 15 were with experimental corn, and trial 
15 only showed contamination in one cooker (\#10). The reason for the large number of contaminated control trials is that due to the limited resources of experimental corn, cooks were only performed with the control corn, which was readily available, until the contamination disappeared from the cooks. In this way the number of clean experimental cooks was maximized. This contamination was initially noticed by the observation of a sulfur note in the odor of the ongoing fermentations. The sulfur note was strongest 24 hours after the fermentation was set and gradually faded over the next 48 hours.

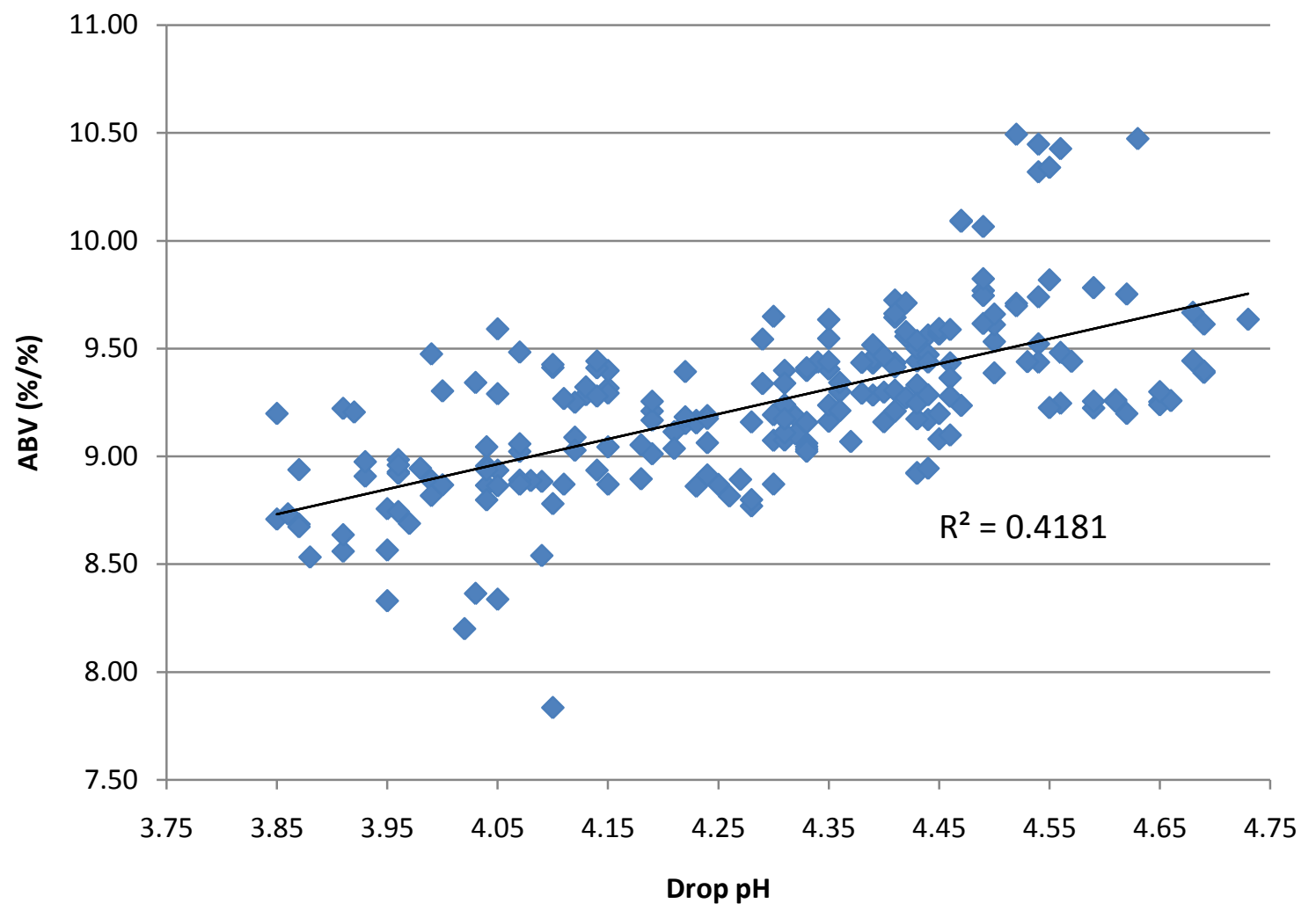

FIGURE 3 - ABV vs Drop pH for all Fermentations. Fermentations with a higher drop $\mathrm{pH}$ also have a higher yield of $\mathrm{ABV}$, both of which correspond to a clean fermentation.

An additional indicator of contamination was the low drop in $\mathrm{pH}$ of the mash. The drop in $\mathrm{pH}$ of a sweet beer, which is what was created here, is typically 4.4 to 4.5 (Geisler, 2006). A pH lower than this range can indicate the presence of excess 
lactobacillus, a bacteria that produces lactic acid. The lactate not only increases the acidity of the mash, it also uses a significant portion of the sugar available to generate that acid, hindering the ethanol production potential of the yeast. This correlation is illustrated in FIGURE 3 above.

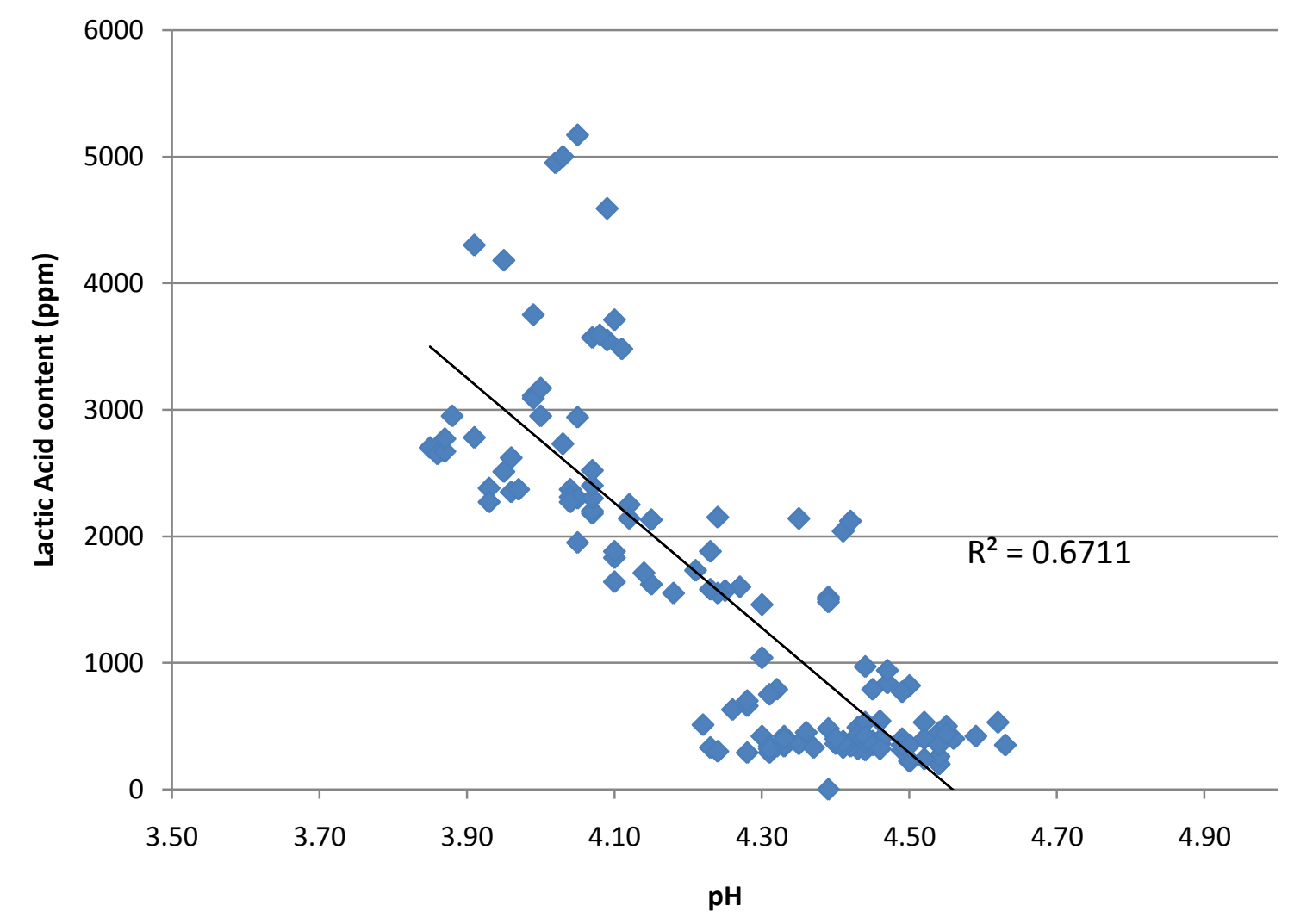

FIGURE 4 - Lactic Acid Content vs Drop pH of Fermentations. When the lactic acid content of the mash is graphed versus the $\mathrm{pH}$, their inverse relationship can be clearly observed.

HPLC analysis was performed on the first 19 trials, yielding data for 137 fermentations, in order to establish a correlation between the $\mathrm{pH}$ of the mash and its lactic acid content. As can be seen in FIGURE 4, there is a definite trend that as the lactic acid in the mash increases, the $\mathrm{pH}$ of the sample decreases. This is illustrated via the $\mathrm{R}$ squared value of 0.6711 for the data. Having thus been determined, the more in-depth 
HPLC analysis can be eliminated for the remainder of the trials, relying instead on the $\mathrm{pH}$ analysis alone.

Since the $\mathrm{pH}$ is a sufficient indicator of the amount of lactic acid present in the mash, it can be used as the determinant for whether the mash has been contaminated. Based on the standard $\mathrm{pH}$ range for a sweet beer, all the fermentations with a $\mathrm{pH}$ below 4.40 will be considered contaminated while all those with a $\mathrm{pH}$ of 4.40 or greater will be deemed clean. By differentiating between clean and contaminated cooks, it is possible to eliminate those trials that would compromise the data when examined as a whole. While comparing clean control trials to clean experimental trials would produce the strongest correlation between the two types of corn, a comparison of the contaminated trials could provide supporting evidence. The differentiation of fermentations into the categories of clean and contaminated can be seen below in TABLE I.

\section{TABLE I}

\section{DIVISION OF CLEAN AND CONTAMINATED COOKS}

\begin{tabular}{|c|c|c|c|c|}
\hline \multicolumn{2}{|c|}{} & $\begin{array}{c}\text { \# of } \\
\text { Fermentations }\end{array}$ & $\begin{array}{c}\text { Average } \\
\text { Drop } \mathrm{pH}\end{array}$ & $\begin{array}{c}\text { Average } \\
\text { ABV }(\%)\end{array}$ \\
\hline \multirow{2}{*}{$\begin{array}{c}\text { Overall } \\
\end{array}$} & All & 218 & 4.29 & 9.24 \\
\cline { 2 - 5 } & Control & 158 & 4.25 & 9.12 \\
\cline { 2 - 5 } & HTF & 60 & 4.41 & 9.58 \\
\hline \multirow{2}{*}{$\begin{array}{c}\text { Contaminated } \\
(\mathrm{pH}<4.40)\end{array}$} & Control & 117 & 4.15 & 9.04 \\
\cline { 2 - 5 } & HTF & 16 & 4.21 & 9.28 \\
\hline $\begin{array}{c}\text { Clean } \\
(\mathrm{pH} \geq 4.40)\end{array}$ & Control & 41 & 4.53 & 9.34 \\
\cline { 2 - 5 } & HTF & 44 & 4.48 & 9.69 \\
\hline
\end{tabular}

From the table above it is easily shown that the vast majority of the contaminated fermentations were those done with control corn. The raw data for all trials can be found in Appendix C. TABLE IV contains the raw corn properties, TABLE V contains set data, and TABLE VI contains the drop data. HPLC data can be found in TABLE VII and 
GC data can be found in TABLE VIII. It is worthy of note that while there may have been variation in $\mathrm{pH}$ and $\mathrm{ABV}$ among the three cookers for any given trial, the three separate fermentations from a single cooker were consistent among themselves. Because of this, it can be confidently stated that the origin of the contamination was not found in the fermenting process.

Due to the wide range of variables inherent in this project, it was difficult to determine the cause of contamination. The control corn acquired from Toney, Alabama (32W86 and 33M54) was used in trials 6-10, 13, 16, 18, and 20, all of which were contaminated, excluding trial 10. This may seem to indicate that this lot of corn was the contaminant; however, this is improbable for two reasons. There were three other strains of corn that showed contamination, two of which were HTF (34M94 and 31G66) and one of which was non-HTF (34D71). Also, in the mashing procedure, the corn is boiled for 20 minutes, which would effectively kill any bacteria present in the grain.

When the contamination first presented itself, it was noticed that the malt being used in the mash had a musty odor. Unlike the corn, the malt was never heated above $170^{\circ} \mathrm{F}$ while in the mash, making it a viable contamination source. A sample of the malt was analyzed for levels of bacteria present. A malt broth was made and plated on three different types of media. It was found that the bacteria levels in the malt were 5-10 times the allowable limits. However, as this malt had aged for several weeks between the time of its use and its testing, it could not be confidently concluded that the malt was the source of contamination. This suspect malt was used in trials 6-12 and 15-18. For the other trials, alternative lots of malt were utilized as available. 
Following the fourth trial, the back culture of the yeast being used for fermentations had to be restarted when it was noticed that there was mold floating on top of the yeast media. While this may have contributed to the low yields seen in trial 3 , it could not be responsible for any subsequent contaminated trials.

A mechanical possibility for the contamination is the cooling rate of the mash. If the mash is not cooled quickly enough after the addition of the post-malt, hot spots can form and cause the mash to partially solidify. This gelatinized mash allows the bacteria already present in the mash to thrive uninhibited since the added yeast cannot penetrate the solid portions of the mash. Since the cooling water used was simply city water, the temperature outside significantly affects the cooling ability. Because the trials took place from mid-August to mid-December, it could be argued that this is the reason the last four trials were clean. However, this disregards that trials 1, 2, 4, and 5 were all clean and took place during the hottest weather of the trial period.

In addition to performing analysis in an attempt to determine the contaminant, the cookers were also rigorously cleaned and sterilized before and after every trial. However, before the source of contamination could be firmly established, the contamination traits gradually declined and finally disappeared altogether over a series of trials without any percievable change in procedure.

Analysis of the clean cooks only yields the most significant data as it has not been compromised by contamination. The conversion of starch to sugar of the different strains of corn can be compared as seen in TABLE IX in Appendix D. The potential $\mathrm{CO}_{2}$ loss is measured prior to milling by the Foss NIR while the actual $\mathrm{CO}_{2}$ loss is calculated by determining the weight lost by the mash over the five day fermentation period. Thus it 
can be seen that, when examined overall, the HTF corn has a slightly better conversion of starch to sugar, at $93.7 \%$, than the control corn, at $92.8 \%$.

Below, FIGURE 5 displays the individual conversions achieved by the HTF and control strains. While the majority of the HTF strains reached over $92 \%$ conversion, two strains (31G66 and 33N54) performed substantially more poorly at about $88.5 \%$. Since only one cook was conducted with each HTF strain, it cannot conclusively be stated that those strains are inferior to the others. Additional testing with corroborating data would be required. It is of note that four hybrid strains (33A84, 34P88, 32K22, and 35Y33) outperformed all of the control strains in the conversion of starch to sugar. The variability in the conversion of starch to sugar is the result of not only the amount of fermentable starch present, but also the accessability of that starch within the corn.

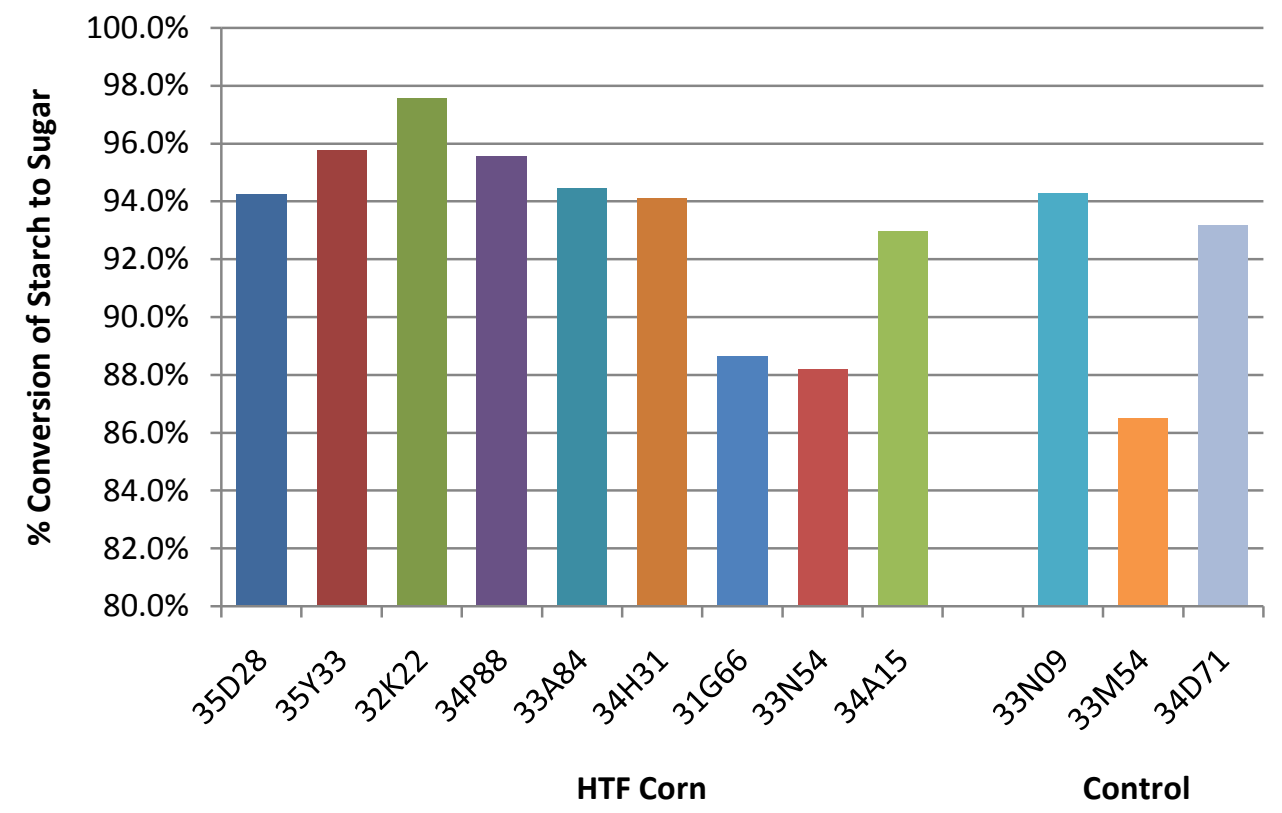

FIGURE 5 - Conversion of Starch to Sugar by Strain

Unlike the conversion from starch, the conversion of sugar to ethanol is, on average, the same for both types of corn. As can be seen from FIGURE 6, while there is 
some variation among the different strains of corn used (see Appendix D), both the control and the HTF corns have an average $95.4 \%$ conversion of sugar to ethanol in a clean fermentation.

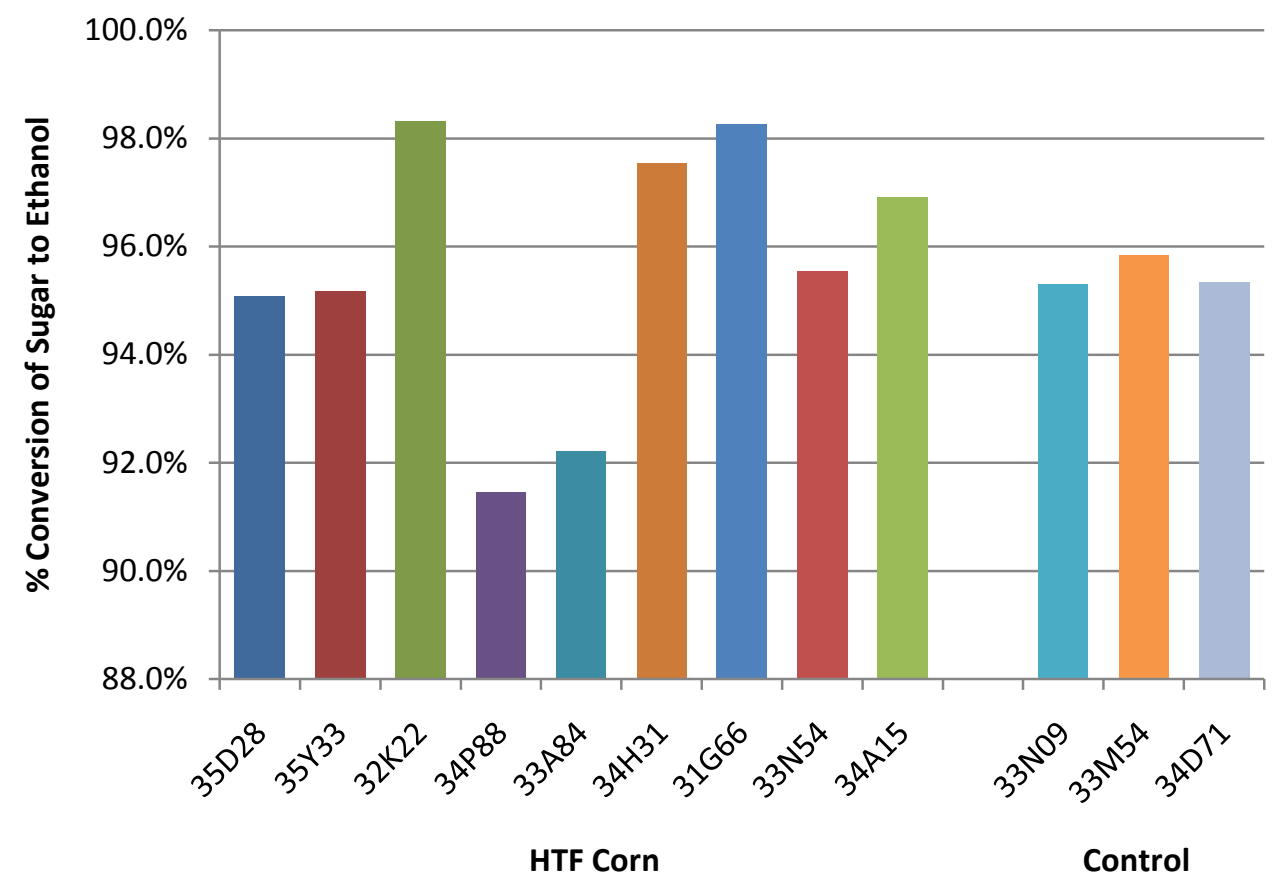

FIGURE 6 - Conversion of Sugar to Ethanol by Strain

In contrast to the conversion of starch, the conversion of sugar percentages achieved by the control strains were extremely consistent, all within $0.5 \%$ of each other. The HTF strains, however, showed considerably more deviation. Two strains (34P88 and 33A84) performed particularly poorly when compared to the other HTF strains, achieving only $92.2 \%$ and $91.5 \%$ conversion, respectively. It is interesting to note that both of these low-performance strains were two of the high-performing strains with regards to starch conversion to sugar. Once again, four of the HTF strains $(32 \mathrm{~K} 22,34 \mathrm{H} 31,31 \mathrm{G} 66$, and 34A15) outperformed all of the tested control strains. Of these, the only strain that demonstrated peak performance for both the conversion of starch to sugar as well as 
sugar to ethanol was $32 \mathrm{~K} 22$. As mentioned earlier, the success or failure of a particular strain cannot be stated conclusively without additional testing.

TABLE II

STRAIN CONVERSION AND ETHANOL PRODUCTION

\begin{tabular}{|c|c|c|c|c|c|}
\hline \multirow{3}{*}{$\begin{array}{c}\text { Corn } \\
\text { Type }\end{array}$} & Strain & $\begin{array}{c}\text { Conversion } \\
\text { of Starch } \\
\text { to Sugar }\end{array}$ & $\begin{array}{c}\text { Conversion } \\
\text { of Sugar to } \\
\text { EtOH }\end{array}$ & $\begin{array}{c}\text { Conversion } \\
\text { of Starch } \\
\text { to EtOH }\end{array}$ & $\begin{array}{c}\text { Average } \\
\text { ABV (\%) }\end{array}$ \\
\hline \hline \multirow{4}{*}{ HTF } & All & $93.7 \%$ & $95.4 \%$ & $89.4 \%$ & 9.69 \\
\cline { 2 - 6 } & $35 \mathrm{D} 28$ & $94.2 \%$ & $95.1 \%$ & $89.6 \%$ & 9.52 \\
\cline { 2 - 6 } & $35 \mathrm{Y} 33$ & $95.8 \%$ & $95.2 \%$ & $91.1 \%$ & 9.62 \\
\cline { 2 - 6 } & $32 \mathrm{~K} 22$ & $97.6 \%$ & $98.3 \%$ & $95.9 \%$ & 10.42 \\
\cline { 2 - 6 } & $34 \mathrm{P} 88$ & $95.6 \%$ & $91.5 \%$ & $87.4 \%$ & 9.85 \\
\cline { 2 - 6 } & $33 \mathrm{~A} 84$ & $94.4 \%$ & $92.2 \%$ & $87.1 \%$ & 9.70 \\
\cline { 2 - 6 } & $34 \mathrm{H} 31$ & $94.1 \%$ & $97.5 \%$ & $91.8 \%$ & 9.50 \\
\cline { 2 - 6 } & $31 \mathrm{G} 66$ & $88.6 \%$ & $98.2 \%$ & $87.1 \%$ & 9.12 \\
\cline { 2 - 6 } & $33 \mathrm{~N} 54$ & $88.2 \%$ & $95.5 \%$ & $84.3 \%$ & 9.43 \\
\cline { 2 - 6 } & $34 \mathrm{~A} 15$ & $92.9 \%$ & $96.9 \%$ & $90.1 \%$ & 9.64 \\
\hline \multirow{6}{*}{ Control } & All & $92.8 \%$ & $95.4 \%$ & $88.5 \%$ & 9.34 \\
\cline { 2 - 6 } & $33 \mathrm{~N} 09$ & $94.3 \%$ & $95.3 \%$ & $89.9 \%$ & 9.56 \\
\cline { 2 - 6 } & $33 \mathrm{M} 54$ & $86.5 \%$ & $95.8 \%$ & $82.9 \%$ & 8.93 \\
\cline { 2 - 6 } & $34 \mathrm{D} 71$ & $93.2 \%$ & $95.3 \%$ & $88.8 \%$ & 9.34 \\
\hline
\end{tabular}

When the conversion capabilities of a strain are compiled in TABLE II along with the alcohol content achieved, it becomes apparent that the HTF strain $32 \mathrm{~K} 22$ is indeed, for this set of trials, superior to the control strains as well as the other HTF strains. The $32 \mathrm{~K} 22 \mathrm{HTF}$ strain achieved an average conversion of $97.6 \%$ of starch to sugar and $98.3 \%$ of sugar to ethanol, leading to an overall starch to ethanol conversion of $95.9 \%$ which is significantly higher than the average overall conversion, $89.4 \%$, for all HTF strains. This enhanced performance can be seen even more clearly when the $32 \mathrm{~K} 22 \mathrm{HTF}$ strain is held in contrast to the average overall conversion, $88.5 \%$, for all of the control strains tested. When examined individually, four of the HTF strains (34A15, 34H31, 32K22, and 35Y33) achieved a greater overall conversion than all of the control strains tested. 
While there was a great deal of variation among the different fermentations, the duplicate distillations performed for any given fermentation displayed excellent repeatability. Ninety-nine percent of the clean fermentations had distillation runs that differed by $0.031 \%$ or less from the average ABV for that particular fermentation.

Using statistical analysis (see Appendix E), it was calculated that, for a $99 \%$ confidence level, the average ABV produced by the HTF corn in a clean fermentation was $9.69 \% \pm 0.14 \%$. In contrast, the control corn produced an average of $9.34 \% \pm 0.08 \%$ ABV for a clean fermentation at a $99 \%$ confidence level. This difference indicates a $3.6 \%$ increase in the alcohol yield of the HTF corn over the control, which corresponds with the $2-4 \%$ yield increase claimed by Pioneer. This increase of alcohol produced per fermentation would result in the ability to decrease the number of fermenations needed to maintain the current level of saleable product while at the same time reducing the energy and time needed in order to run those now-superfluous fermentations.

TABLE III

AVERAGE VALUES OF TRIAL DATA

\begin{tabular}{|c|c|c|c|c|c|c|c|c|}
\hline & & \# & $\begin{array}{c}\mathrm{CO}_{2} \\
\operatorname{loss}(\mathrm{g})\end{array}$ & $\begin{array}{c}\text { Set Balling } \\
(\%)\end{array}$ & $\begin{array}{c}\text { Drop } \\
\text { Balling } \\
(\%)\end{array}$ & $\begin{array}{l}\text { Set } \\
\mathrm{pH}\end{array}$ & $\begin{array}{l}\text { Drop } \\
\mathrm{pH}\end{array}$ & $\begin{array}{l}\text { Average } \\
\text { ABV (\%) }\end{array}$ \\
\hline \multirow[t]{3}{*}{ Overall } & All & 218 & 38.5 & 18.4 & 1.0 & 5.93 & 4.29 & 9.24 \\
\hline & Control & 158 & 38.5 & 18.3 & 1.0 & 5.96 & 4.25 & 9.12 \\
\hline & HTF & 60 & 38.6 & 18.6 & 0.9 & 5.84 & 4.41 & 9.58 \\
\hline \multirow{2}{*}{$\begin{array}{c}\text { Contaminated } \\
(\mathrm{pH}<4.40)\end{array}$} & Control & 117 & 38.4 & 18.3 & 1.1 & 5.96 & 4.15 & 9.04 \\
\hline & HTF & 16 & 38.6 & 18.5 & 1.1 & 5.89 & 4.21 & 9.28 \\
\hline \multirow{2}{*}{$\begin{array}{c}\text { Clean } \\
(\mathrm{pH} \geq 4.40)\end{array}$} & Control & 41 & 38.5 & 18.6 & 0.9 & 5.98 & 4.53 & 9.34 \\
\hline & HTF & 44 & 38.6 & 18.6 & 0.9 & 5.82 & 4.48 & 9.69 \\
\hline
\end{tabular}

When an identical analysis was performed on the contaminated trials, it was found that the trends between the HTF and control corns were similar to those observed 
in the clean fermentations. In TABLE III, the results are compared both overall as well as between contaminated and clean fermentations.

When the contaminated fermentations were analyzed statistically (Appendix E), it was found that for a 99\% confidence level HTF and control corn yielded 9.28\% $\pm 0.11 \%$ $\mathrm{ABV}$ and $9.04 \% \pm 0.07 \% \mathrm{ABV}$ respectively. From this it can be seen that even when contaminated, the HTF corn managed to provide a $2.6 \%$ increase in the alcohol yield over that produced by the control corn. While this trend is not as strongly significant as the data obtained from the clean fermentations due to being compromised by contamination, it can be looked upon as supporting evidence of the claim that HTF corn produces a higher ethanol yield than the non-HTF control corn. This outcome is not entirely unexpected since the suspected contaminant was a lactic acid-producing bacteria. The bacteria used the sugar created during the mashing process to create lactic acid, simultaneously depriving the yeast of needed nutrients and creating an environment where the $\mathrm{pH}$ was below the optimum operating conditions of the yeast. However, if the contamination was present to roughly the same degree in the different fermentations, the ethanol producing capabilities of the HTF and control strains would be decreased by the same amount. This, of course, varies with respect to the initial amount of starch present in the corn as well as the conversion of that starch to sugar achieved by that particular strain.

While the increase in the clean fermentations of $3.6 \%$ does not seem to be greatly significant, when moved to an industrial scale, it becomes much more noteworthy. Not only is this a simple means of enhancing the process, it also enhances the profit margin without incurring large, if any, expenses. 


\section{CONCLUSIONS}

There are several conclusions that can be reached based on the findings of this experimentation. These findings are valid only for the procedure followed and the strains of corn utilized, both control (33N09, 32W86, 33M54, and 34D71) and HTF (35D28, 35Y33, 34M94, 32K22, 34P88, 33A84, 34H31, 31G66, 33N56, and 34A15).

- There is a directly proportional trend between the $\mathrm{pH}$ of a fermentation and its lactic acid content, thus allowing it to be used as a means of determining contamination.

- For clean fermentations, HTF corn reaches an average $93.7 \%$ conversion of starch to sugar and control corn reaches $92.8 \%$; however, both HTF and control corn achieve an average $95.4 \%$ conversion of sugar to ethanol for clean fermentations.

- From a preliminary standpoint, the HTF strain 32K22 is the most successful of the strains with $97.6 \%$ conversion of starch to sugar, $98.3 \%$ conversion of sugar to ethanol, $95.9 \%$ conversion of starch to ethanol, and a final alcohol content of $10.42 \% \mathrm{ABV}$.

- Under a $99 \%$ confidence level, a clean HTF fermentation yields $9.69 \% \pm 0.14 \%$ $\mathrm{ABV}$ and a clean control fermentation yields $9.34 \% \pm 0.08 \% \mathrm{ABV}$; a contaminated HTF fermentation yields $9.28 \% \pm 0.11 \%$ ABV and a contaminated control fermentation yields $9.04 \% \pm 0.08 \% \mathrm{ABV}$.

- A clean HTF fermentation produces, on average, 3.6\% more ethanol than a clean control fermentation, falling in the range advertised by Pioneer of 2-4\%. A 
contaminated HTF fermentation produces an average of $2.6 \%$ more ethanol than a contaminated fermentation, also falling within Pioneer's range.

- The optimum HTF strain, $32 \mathrm{~K} 22$, achieves a $11.6 \%$ increase in ethanol content over the average produced by the clean control fermentations. 


\section{RECOMMENDATIONS}

The primary recommendation that can be made at the close of this experimentation is that the HTF corn, particularly $32 \mathrm{~K} 22$, be utilized in the production of whisky in conjunction with, if not in lieu of, non-HTF corn. By using a superior raw material, the process can be upgraded at a minimal cost and simultaneously preserve the integrity with which the whisky industry regards the tradition of whisky production.

In order to determine the best strains to blend together for the optimal alcohol production, additional trials should be done with the HTF strains in order to determine conclusively which have the best conversion capabilities and produce the most alcohol.

The improvement of the process could potentially be advanced through additional enhancement of the grains used in the mashing process. Perhaps the best candidate for this would be the development of malt with an increased amount of amylase enzymes. This could allow for a more complete conversion of starch to sugar during the mashing process, providing more ample resources for the yeast when converting sugar to ethanol. 


\section{REFERENCES CITED}

Alcohol and Tobacco Tax and Trade Bureau. "Distilled Spirits: Laws and Regulations." 2008. http://www.ttb.gov/spirits/spirits_regs.shtml. Accessed 16 October, 2008.

Briggs, D., Boulton, C. A., Brookes, P. A., and Stevens, R. 2004. Brewing: Science and Practice. Cambridge, England: Woodhead Publishing.

"Fermentability and mashing out." Brew Your Own: The How-to Homebrew Beer Magazine. (November 2005).

Ferris, R. "Distilled liquors," The Encyclopedia Americana, 1918 ed.

FOSS. "Dedicated Analytical Systems.” 2008. http://www.foss.dk/Solutions/ProductsDirect/Infratec1241GrainAnalyzer.aspx. Accessed 25 September, 2008.

Geisler, C. 2006. Private communication.

H\&C Sieving Systems. "12 Inch Diameter Sieves.” 2008. http://www.affordablesieves.com/12_inch_sieves.htm. Accessed 2 October, 2008.

Hough, J. S. 1991. The Biotechnology of Malting and Brewing. Cambridge, England: Cambridge University Press.

Najafpour, G.D. and Lim, J.K. 2002. Evaluation and Isolation of Ethanol Producer Strain SMP-6. Regional Symposium on Chemical Engineering (Malaysia).

Nielsen, S. 2003. Food Analysis Laboratory Manual. New York: Springer.

Nollet, L. 2000. Food Analysis by HPLC. New York: CRC Press.

Pioneer Hi-Bred International, Inc. "Increased Ethanol Production.” 2008. http://www.pioneer.com/CMRoot/pioneer/research/pipeline/spec_sheets/Ethanol. pdf. Accessed 10 September, 2008. 


\section{APPENDIX A}

\section{SAMPLE CALCULATION OF GRAIN BILL}

$$
\begin{gathered}
\frac{25 . \text { liters.mash }}{3.785 \frac{\mathrm{L}}{\text { gal }}} \times \frac{56 \frac{\mathrm{lb}}{\text { bushel.grain }}}{28 . \text { beer.gallonage. }\left(\frac{\text { gal.mash }}{\text { ushel.grain }}-\right.} \times 0.454 \frac{\mathrm{kg}}{\mathrm{lb}}=6.0 \mathrm{~kg} \text { of grain } \\
25 \mathrm{~L} \text { of mash }-\frac{0.637 \mathrm{~L}}{\mathrm{~kg}} \times 6.0 \mathrm{~kg} \text { of grain }=21.2 \mathrm{~L} \text { of water }
\end{gathered}
$$

\begin{tabular}{|l|l|}
\hline Grain & Volume \\
\hline Corn & $4,800 \mathrm{~g}$ \\
\hline Malt & $\begin{array}{l}72 \mathrm{~g} \text { as pre-malt } \\
648 \mathrm{~g} \text { as post-malt }\end{array}$ \\
\hline Rye & $480 \mathrm{~g}$ \\
\hline
\end{tabular}




\section{APPENDIX B}

\section{MILLED CORN SIZE SPECIFICATIONS}

\begin{tabular}{|c|c|c|c|}
\hline Sieve & $\begin{array}{c}\text { Specs } \\
\text { Max \% }\end{array}$ & $\begin{array}{c}\text { Specs } \\
\text { Min \% }\end{array}$ & $\begin{array}{c}\text { Specs } \\
\text { Goal \% }\end{array}$ \\
\hline$\# 10$ & 5 & 0 & $<3$ \\
\hline$\# 20$ & 46 & 20 & $<35$ \\
\hline$\# 40$ & 31 & 18 & $<27$ \\
\hline$\# 60$ & 16 & 9 & $<10$ \\
\hline$\# 80$ & 8 & 4 & $>5$ \\
\hline$\# 100$ & 7 & 1 & $>3$ \\
\hline Flour & 28 & 5 & $>13$ \\
\hline
\end{tabular}




\section{APPENDIX C}

RAW DATA

TABLE IV

RAW CORN PROPERTIES

\begin{tabular}{|c|c|c|c|c|c|c|c|}
\hline Set Date & Strain & Corn Type & ID & Max Theo $\mathrm{CO}_{2}$ loss & $\%$ Moisture & Cooker \# & Cook Size Theo (L) \\
\hline \multirow{3}{*}{$\begin{array}{l}8 / 17 / 2006 \\
8 / 17 / 2006 \\
8 / 17 / 2006\end{array}$} & $35 \mathrm{D} 28$ & HTF & \multirow{3}{*}{$\begin{array}{l}1 \mathrm{~A} 9 \\
1 \mathrm{~B} 9 \\
1 \mathrm{C} 9 \\
\end{array}$} & 38.4 & \multirow{3}{*}{$\begin{array}{l}14.4 \% \\
14.4 \% \\
14.4 \% \\
\end{array}$} & \multirow{3}{*}{$\begin{array}{l}9 \\
9 \\
9\end{array}$} & \multirow{3}{*}{$\begin{array}{l}22.2 \\
22.2 \\
22.2\end{array}$} \\
\hline & $35 \mathrm{D} 28$ & HTF & & 38.4 & & & \\
\hline & $35 \mathrm{D} 28$ & HTF & & 38.4 & & & \\
\hline \multirow{3}{*}{$\begin{array}{l}8 / 17 / 2006 \\
8 / 17 / 2006 \\
8 / 17 / 2006 \\
\end{array}$} & $35 \mathrm{D} 28$ & HTF & \multirow{3}{*}{$\begin{array}{l}1 \mathrm{~A} 10 \\
1 \mathrm{~B} 10 \\
1 \mathrm{C} 10 \\
\end{array}$} & 38.4 & \multirow{3}{*}{$\begin{array}{l}14.4 \% \\
14.4 \% \\
14.4 \% \\
\end{array}$} & \multirow{3}{*}{$\begin{array}{l}10 \\
10 \\
10\end{array}$} & \multirow{3}{*}{$\begin{array}{l}22.2 \\
22.2 \\
22.2 \\
\end{array}$} \\
\hline & $35 \mathrm{D} 28$ & HTF & & 38.4 & & & \\
\hline & $35 \mathrm{D} 28$ & HTF & & 38.4 & & & \\
\hline \multirow{3}{*}{$\begin{array}{l}8 / 18 / 2006 \\
8 / 18 / 2006 \\
8 / 18 / 2006 \\
\end{array}$} & $35 \mathrm{Y} 33$ & HTF & \multirow{3}{*}{$\begin{array}{l}2 \mathrm{~A} 9 \\
2 \mathrm{~B} 9 \\
2 \mathrm{C} 9 \\
\end{array}$} & 38.1 & \multirow{3}{*}{$\begin{array}{l}12.8 \% \\
12.8 \% \\
12.8 \% \\
\end{array}$} & \multirow{3}{*}{$\begin{array}{l}9 \\
9 \\
9 \\
\end{array}$} & \multirow{3}{*}{$\begin{array}{l}24.5 \\
24.5 \\
24.5 \\
\end{array}$} \\
\hline & $35 \mathrm{Y} 33$ & HTF & & 38.1 & & & \\
\hline & $35 \mathrm{Y} 33$ & HTF & & 38.1 & & & \\
\hline \multirow{3}{*}{$\begin{array}{l}8 / 18 / 2006 \\
8 / 18 / 2006 \\
8 / 18 / 2006 \\
\end{array}$} & $35 \mathrm{Y} 33$ & HTF & \multirow{3}{*}{$\begin{array}{l}2 \mathrm{~A} 10 \\
2 \mathrm{~B} 10 \\
2 \mathrm{C} 10 \\
\end{array}$} & 38.1 & \multirow{3}{*}{$\begin{array}{l}12.8 \% \\
12.8 \% \\
12.8 \% \\
\end{array}$} & \multirow{3}{*}{$\begin{array}{r}10 \\
10 \\
10 \\
\end{array}$} & \multirow{3}{*}{$\begin{array}{l}24.5 \\
24.5 \\
24.5 \\
\end{array}$} \\
\hline & $35 \mathrm{Y} 33$ & HTF & & 38.1 & & & \\
\hline & $35 \mathrm{Y} 33$ & HTF & & 38.1 & & & \\
\hline \multirow{3}{*}{$\begin{array}{l}8 / 24 / 2006 \\
8 / 24 / 2006 \\
8 / 24 / 2006 \\
\end{array}$} & 34M94 & HTF & \multirow{3}{*}{$\begin{array}{l}3 \mathrm{~A} 9 \\
3 \mathrm{~B} 9 \\
3 \mathrm{C} 9 \\
\end{array}$} & 38.8 & \multirow{3}{*}{$\begin{array}{l}13.0 \% \\
13.0 \% \\
13.0 \% \\
\end{array}$} & \multirow{3}{*}{$\begin{array}{l}9 \\
9 \\
9 \\
\end{array}$} & \multirow{3}{*}{$\begin{array}{l}22.1 \\
22.1 \\
22.1 \\
\end{array}$} \\
\hline & 34M94 & HTF & & 38.8 & & & \\
\hline & 34M94 & HTF & & 38.8 & & & \\
\hline \multirow{3}{*}{$\begin{array}{l}8 / 24 / 2006 \\
8 / 24 / 2006 \\
8 / 24 / 2006 \\
\end{array}$} & 34M94 & HTF & $3 \mathrm{~A} 10$ & 38.8 & $13.0 \%$ & 10 & 22.1 \\
\hline & 34M94 & HTF & $3 \mathrm{~B} 10$ & 38.8 & $13.0 \%$ & 10 & 22.1 \\
\hline & 34M94 & HTF & $3 \mathrm{C} 10$ & 38.8 & $13.0 \%$ & 10 & 22.1 \\
\hline $8 / 25 / 2006$ & 33N09 & Control & $4 \mathrm{~A} 9$ & 38.4 & $13.0 \%$ & 9 & 23.4 \\
\hline $8 / 25 / 2006$ & 33 N09 & Control & $4 \mathrm{~B} 9$ & 38.4 & $13.0 \%$ & 9 & 23.4 \\
\hline $8 / 25 / 2006$ & 33N09 & Control & $4 \mathrm{C} 9$ & 38.4 & $13.0 \%$ & 9 & 23.4 \\
\hline $8 / 25 / 2006$ & 33N09 & Control & $4 \mathrm{~A} 10$ & 38.4 & $13.0 \%$ & 10 & 23.4 \\
\hline $8 / 25 / 2006$ & 33N09 & Control & 4B10 & 38.4 & $13.0 \%$ & 10 & 23.4 \\
\hline 9/8/2006 & $32 \mathrm{~K} 22$ & HTF & $5 \mathrm{~A} 9$ & 38.5 & $13.6 \%$ & 9 & 23.1 \\
\hline 9/8/2006 & $32 \mathrm{~K} 22$ & HTF & $5 \mathrm{~B} 9$ & 38.5 & $13.6 \%$ & 9 & 23.1 \\
\hline $9 / 8 / 2006$ & $32 \mathrm{~K} 22$ & HTF & $5 \mathrm{C} 9$ & 38.5 & $13.6 \%$ & 9 & 23.1 \\
\hline $9 / 8 / 2006$ & $32 \mathrm{~K} 22$ & HTF & $5 \mathrm{~A} 10$ & 38.5 & $13.6 \%$ & 10 & 23.1 \\
\hline 9/8/2006 & $32 \mathrm{~K} 22$ & HTF & $5 \mathrm{~B} 10$ & 38.5 & $13.6 \%$ & 10 & 23.1 \\
\hline 9/8/2006 & $32 \mathrm{~K} 22$ & $\mathrm{HTF}$ & $5 \mathrm{C} 10$ & 38.5 & $13.6 \%$ & 10 & 23.1 \\
\hline $9 / 11 / 2006$ & $32 \mathrm{~W} 86$ & Control & $6 \mathrm{~A} 9$ & 38.5 & $13.5 \%$ & 9 & 25.0 \\
\hline $9 / 11 / 2006$ & $32 W 86$ & Control & $6 \mathrm{~B} 9$ & 38.5 & $13.5 \%$ & 9 & 25.0 \\
\hline $9 / 11 / 2006$ & $32 W 86$ & Control & $6 \mathrm{C} 9$ & 38.5 & $13.5 \%$ & 9 & 25.0 \\
\hline $9 / 11 / 2006$ & $32 \mathrm{~W} 86$ & Control & $6 \mathrm{~A} 10$ & 38.5 & $13.5 \%$ & 10 & 25.0 \\
\hline $9 / 11 / 2006$ & $32 W 86$ & Control & $6 \mathrm{~B} 10$ & 38.5 & $13.5 \%$ & 10 & 25.0 \\
\hline $9 / 11 / 2006$ & $32 W 86$ & Control & $6 \mathrm{C} 10$ & 38.5 & $13.5 \%$ & 10 & 25.0 \\
\hline $9 / 11 / 2006$ & $32 W 86$ & Control & $6 \mathrm{~A} 11$ & 38.5 & $13.5 \%$ & 11 & 25.0 \\
\hline 9/11/2006 & $32 \mathrm{~W} 86$ & Control & $6 \mathrm{~B} 11$ & 38.5 & $13.5 \%$ & 11 & 25.0 \\
\hline $9 / 11 / 2006$ & $32 W 86$ & Control & $6 \mathrm{C} 11$ & 38.5 & $13.5 \%$ & 11 & 25.0 \\
\hline
\end{tabular}




\section{TABLE IV}

RAW CORN PROPERTIES CONT.

\begin{tabular}{|c|c|c|c|c|c|c|c|}
\hline Set Date & Strain & Corn Type & ID & Max Theo $\mathrm{CO}_{2}$ loss & $\%$ Moisture & Cooker \# & Cook Size Theo (L) \\
\hline \multirow{3}{*}{$\begin{array}{l}9 / 14 / 2006 \\
9 / 14 / 2006 \\
9 / 14 / 2006 \\
\end{array}$} & $32 \mathrm{~W} 86$ & Control & \multirow{3}{*}{$\begin{array}{l}7 \mathrm{~A} 9 \\
7 \mathrm{~B} 9 \\
7 \mathrm{C} 9 \\
\end{array}$} & \multirow{3}{*}{$\begin{array}{l}38.6 \\
38.6 \\
38.6 \\
\end{array}$} & \multirow{3}{*}{$\begin{array}{l}15.0 \% \\
15.0 \% \\
15.0 \% \\
\end{array}$} & \multirow{3}{*}{$\begin{array}{l}9 \\
9 \\
9 \\
\end{array}$} & \multirow{3}{*}{$\begin{array}{l}25.0 \\
25.0 \\
25.0\end{array}$} \\
\hline & $32 \mathrm{~W} 86$ & Control & & & & & \\
\hline & $32 \mathrm{~W} 86$ & Control & & & & & \\
\hline \multirow{3}{*}{$\begin{array}{l}9 / 14 / 2006 \\
9 / 14 / 2006 \\
9 / 14 / 2006 \\
\end{array}$} & $32 \mathrm{~W} 86$ & Control & \multirow{3}{*}{$\begin{array}{l}7 \mathrm{~A} 10 \\
7 \mathrm{~B} 10 \\
7 \mathrm{C} 10 \\
\end{array}$} & \multirow{3}{*}{$\begin{array}{l}38.6 \\
38.6 \\
38.6 \\
\end{array}$} & \multirow{3}{*}{$\begin{array}{l}15.0 \% \\
15.0 \% \\
15.0 \% \\
\end{array}$} & \multirow{3}{*}{$\begin{array}{l}10 \\
10 \\
10 \\
\end{array}$} & \multirow{3}{*}{$\begin{array}{l}25.0 \\
25.0 \\
25.0 \\
\end{array}$} \\
\hline & $32 \mathrm{~W} 86$ & Control & & & & & \\
\hline & $32 \mathrm{~W} 86$ & Control & & & & & \\
\hline \multirow{3}{*}{$\begin{array}{l}9 / 14 / 2006 \\
9 / 14 / 2006 \\
9 / 14 / 2006 \\
\end{array}$} & $32 \mathrm{~W} 86$ & Control & \multirow{3}{*}{$\begin{array}{l}\text { 7A11 } \\
7 \mathrm{~B} 11 \\
7 \mathrm{C} 11 \\
\end{array}$} & \multirow{3}{*}{$\begin{array}{l}38.6 \\
38.6 \\
38.6 \\
\end{array}$} & \multirow{3}{*}{$\begin{array}{l}15.0 \% \\
15.0 \% \\
15.0 \% \\
\end{array}$} & \multirow{3}{*}{$\begin{array}{l}11 \\
11 \\
11 \\
\end{array}$} & \multirow{3}{*}{$\begin{array}{l}25.0 \\
25.0 \\
25.0 \\
\end{array}$} \\
\hline & $32 \mathrm{~W} 86$ & Control & & & & & \\
\hline & $32 \mathrm{~W} 86$ & Control & & & & & \\
\hline \multirow{3}{*}{$\begin{array}{l}9 / 15 / 2006 \\
9 / 15 / 2006 \\
9 / 15 / 2006 \\
\end{array}$} & 33M54 & Control & \multirow{3}{*}{$\begin{array}{l}8 \mathrm{~A} 9 \\
8 \mathrm{~B} 9 \\
8 \mathrm{C} 9 \\
\end{array}$} & \multirow{3}{*}{$\begin{array}{l}38.2 \\
38.2 \\
38.2 \\
\end{array}$} & \multirow{3}{*}{$\begin{array}{l}15.1 \% \\
15.1 \% \\
15.1 \% \\
\end{array}$} & \multirow{3}{*}{$\begin{array}{l}9 \\
9 \\
9 \\
\end{array}$} & \multirow{3}{*}{$\begin{array}{l}25.0 \\
25.0 \\
25.0 \\
\end{array}$} \\
\hline & 33M54 & Control & & & & & \\
\hline & 33M54 & Control & & & & & \\
\hline $9 / 15 / 2006$ & 33 M54 & Control & $8 \mathrm{~A} 10$ & 38.2 & $15.1 \%$ & 10 & 25.0 \\
\hline $9 / 15 / 2006$ & 33M54 & Control & $8 \mathrm{~B} 10$ & 38.2 & $15.1 \%$ & 10 & 25.0 \\
\hline $9 / 15 / 2006$ & 33M54 & Control & $8 \mathrm{C} 10$ & 38.2 & $15.1 \%$ & 10 & 25.0 \\
\hline $9 / 15 / 2006$ & 33M54 & Control & $8 \mathrm{~A} 11$ & 38.2 & $15.1 \%$ & 11 & 25.0 \\
\hline $9 / 15 / 2006$ & 33M54 & Control & $8 \mathrm{~B} 11$ & 38.2 & $15.1 \%$ & 11 & 25.0 \\
\hline 9/15/2006 & 33M54 & Control & $8 \mathrm{C} 11$ & 38.2 & $15.1 \%$ & 11 & 25.0 \\
\hline $9 / 21 / 2006$ & $32 \mathrm{~W} 86$ & Control & 9A9 & 38.4 & $15.3 \%$ & 9 & 25.0 \\
\hline $9 / 21 / 2006$ & $32 \mathrm{~W} 86$ & Control & 9B9 & 38.4 & $15.3 \%$ & 9 & 25.0 \\
\hline $9 / 21 / 2006$ & $32 \mathrm{~W} 86$ & Control & $9 \mathrm{C} 9$ & 38.4 & $15.3 \%$ & 9 & 25.0 \\
\hline $9 / 21 / 2006$ & $32 \mathrm{~W} 86$ & Control & 9A10 & 38.4 & $15.3 \%$ & 10 & 25.0 \\
\hline $9 / 21 / 2006$ & $32 \mathrm{~W} 86$ & Control & $9 \mathrm{~B} 10$ & 38.4 & $15.3 \%$ & 10 & 25.0 \\
\hline $9 / 21 / 2006$ & $32 \mathrm{~W} 86$ & Control & $9 \mathrm{C} 10$ & 38.4 & $15.3 \%$ & 10 & 25.0 \\
\hline $9 / 21 / 2006$ & $32 \mathrm{~W} 86$ & Control & 9A11 & 38.4 & $15.3 \%$ & 11 & 25.0 \\
\hline $9 / 21 / 2006$ & $32 \mathrm{~W} 86$ & Control & 9B11 & 38.4 & $15.3 \%$ & 11 & 25.0 \\
\hline $9 / 21 / 2006$ & $32 \mathrm{~W} 86$ & Control & $9 \mathrm{C} 11$ & 38.4 & $15.3 \%$ & 11 & 25.0 \\
\hline $9 / 22 / 2006$ & $32 \mathrm{~W} 86$ & Control & $10 \mathrm{~A} 9$ & 38.4 & $14.8 \%$ & 9 & 25.0 \\
\hline $9 / 22 / 2006$ & $32 \mathrm{~W} 86$ & Control & 10B9 & 38.4 & $14.8 \%$ & 9 & 25.0 \\
\hline $9 / 22 / 2006$ & $32 \mathrm{~W} 86$ & Control & $10 \mathrm{C} 9$ & 38.4 & $14.8 \%$ & 9 & 25.0 \\
\hline $9 / 22 / 2006$ & $32 W 86$ & Control & $10 \mathrm{~A} 10$ & 38.4 & $14.8 \%$ & 10 & 25.0 \\
\hline $9 / 22 / 2006$ & $32 \mathrm{~W} 86$ & Control & 10B10 & 38.4 & $14.8 \%$ & 10 & 25.0 \\
\hline $9 / 22 / 2006$ & $32 \mathrm{~W} 86$ & Control & $10 \mathrm{C} 10$ & 38.4 & $14.8 \%$ & 10 & 25.0 \\
\hline $9 / 22 / 2006$ & $32 \mathrm{~W} 86$ & Control & $10 \mathrm{~A} 11$ & 38.4 & $14.8 \%$ & 11 & 25.0 \\
\hline $9 / 22 / 2006$ & $32 \mathrm{~W} 86$ & Control & 10B11 & 38.4 & $14.8 \%$ & 11 & 25.0 \\
\hline $9 / 22 / 2006$ & $32 \mathrm{~W} 86$ & Control & $10 \mathrm{C} 11$ & 38.4 & $14.8 \%$ & 11 & 25.0 \\
\hline $10 / 5 / 2006$ & $34 \mathrm{P} 88$ & HTF & $11 \mathrm{~A} 9$ & 38.4 & $13.8 \%$ & 9 & 20.8 \\
\hline $10 / 5 / 2006$ & $34 \mathrm{P} 88$ & HTF & 11B9 & 38.4 & $13.8 \%$ & 9 & 20.8 \\
\hline $10 / 5 / 2006$ & $34 \mathrm{P} 88$ & HTF & $11 \mathrm{C} 9$ & 38.4 & $13.8 \%$ & 9 & 20.8 \\
\hline $10 / 5 / 2006$ & $34 \mathrm{P} 88$ & HTF & $11 \mathrm{~A} 10$ & 38.4 & $13.8 \%$ & 10 & 20.8 \\
\hline $10 / 5 / 2006$ & $34 \mathrm{P} 88$ & HTF & $11 \mathrm{~B} 10$ & 38.4 & $13.8 \%$ & 10 & 20.8 \\
\hline $10 / 5 / 2006$ & $34 \mathrm{P} 88$ & HTF & $11 \mathrm{C} 10$ & 38.4 & $13.8 \%$ & 10 & 20.8 \\
\hline
\end{tabular}


TABLE IV

RAW CORN PROPERTIES CONT.

\begin{tabular}{|c|c|c|c|c|c|c|c|}
\hline Set Date & Strain & Corn Type & ID & Max Theo $\mathrm{CO}_{2}$ loss & $\%$ Moisture & Cooker \# & Cook Size Theo (L) \\
\hline \multirow{3}{*}{$\begin{array}{l}10 / 6 / 2006 \\
10 / 6 / 2006 \\
10 / 6 / 2006 \\
\end{array}$} & $33 \mathrm{~A} 84$ & HTF & \multirow{3}{*}{$\begin{array}{l}12 \mathrm{~A} 9 \\
12 \mathrm{~B} 9 \\
12 \mathrm{C} 9 \\
\end{array}$} & \multirow{3}{*}{$\begin{array}{l}38.7 \\
38.7 \\
38.7 \\
\end{array}$} & \multirow{3}{*}{$\begin{array}{l}13.5 \% \\
13.5 \% \\
13.5 \% \\
\end{array}$} & \multirow{3}{*}{$\begin{array}{l}9 \\
9 \\
9 \\
\end{array}$} & \multirow{3}{*}{$\begin{array}{r}20.8 \\
20.8 \\
20.8 \\
\end{array}$} \\
\hline & $33 \mathrm{~A} 84$ & HTF & & & & & \\
\hline & $33 \mathrm{~A} 84$ & HTF & & & & & \\
\hline \multirow{3}{*}{$\begin{array}{l}10 / 6 / 2006 \\
10 / 6 / 2006 \\
10 / 6 / 2006 \\
\end{array}$} & $33 \mathrm{~A} 84$ & HTF & \multirow{3}{*}{$\begin{array}{l}12 \mathrm{~A} 10 \\
12 \mathrm{~B} 10 \\
12 \mathrm{C} 10 \\
\end{array}$} & \multirow{3}{*}{$\begin{array}{l}38.7 \\
38.7 \\
38.7 \\
\end{array}$} & \multirow{3}{*}{$\begin{array}{l}13.5 \% \\
13.5 \% \\
13.5 \% \\
\end{array}$} & \multirow{3}{*}{$\begin{array}{l}10 \\
10 \\
10 \\
\end{array}$} & \multirow{3}{*}{$\begin{array}{l}20.8 \\
20.8 \\
20.8 \\
\end{array}$} \\
\hline & $33 \mathrm{~A} 84$ & HTF & & & & & \\
\hline & 33A84 & HTF & & & & & \\
\hline \multirow{3}{*}{$\begin{array}{l}10 / 12 / 2006 \\
10 / 12 / 2006 \\
10 / 12 / 2006 \\
\end{array}$} & 33M54 & Control & \multirow{3}{*}{$\begin{array}{l}13 \mathrm{~A} 9 \\
13 \mathrm{~B} 9 \\
13 \mathrm{C} 9 \\
\end{array}$} & \multirow{3}{*}{$\begin{array}{l}38.1 \\
38.1 \\
38.1 \\
\end{array}$} & \multirow{3}{*}{$\begin{array}{l}13.8 \% \\
13.8 \% \\
13.8 \% \\
\end{array}$} & \multirow{3}{*}{$\begin{array}{l}9 \\
9 \\
9 \\
\end{array}$} & \multirow{3}{*}{$\begin{array}{l}25.0 \\
25.0 \\
25.0 \\
\end{array}$} \\
\hline & 33M54 & Control & & & & & \\
\hline & 33M54 & Control & & & & & \\
\hline \multirow{3}{*}{$\begin{array}{l}10 / 12 / 2006 \\
10 / 12 / 2006 \\
10 / 12 / 2006 \\
\end{array}$} & 33M54 & Control & \multirow{3}{*}{$\begin{array}{l}13 \mathrm{~A} 10 \\
13 \mathrm{~B} 10 \\
13 \mathrm{C} 10 \\
\end{array}$} & \multirow{3}{*}{$\begin{array}{l}38.1 \\
38.1 \\
38.1 \\
\end{array}$} & \multirow{3}{*}{$\begin{array}{l}13.8 \% \\
13.8 \% \\
13.8 \% \\
\end{array}$} & \multirow{3}{*}{$\begin{array}{l}10 \\
10 \\
10 \\
\end{array}$} & \multirow{3}{*}{$\begin{array}{l}25.0 \\
25.0 \\
25.0 \\
\end{array}$} \\
\hline & 33M54 & Control & & & & & \\
\hline & $33 \mathrm{M} 54$ & Control & & & & & \\
\hline $10 / 12 / 2006$ & $33 \mathrm{M} 54$ & Control & $13 \mathrm{~A} 11$ & 38.1 & $13.8 \%$ & 11 & 25.0 \\
\hline $10 / 12 / 2006$ & 33M54 & Control & 13B11 & 38.1 & $13.8 \%$ & 11 & 25.0 \\
\hline $10 / 12 / 2006$ & $33 \mathrm{M} 54$ & Control & $13 \mathrm{C} 11$ & 38.1 & $13.8 \%$ & 11 & 25.0 \\
\hline $10 / 13 / 2006$ & $34 \mathrm{H} 31$ & HTF & $14 \mathrm{~A} 9$ & 38.5 & $12.5 \%$ & 9 & 23.4 \\
\hline $10 / 13 / 2006$ & $34 \mathrm{H} 31$ & HTF & 14B9 & 38.5 & $12.5 \%$ & 9 & 23.4 \\
\hline $10 / 13 / 2006$ & $34 \mathrm{H} 31$ & HTF & $14 \mathrm{C} 9$ & 38.5 & $12.5 \%$ & 9 & 23.4 \\
\hline $10 / 13 / 2006$ & $34 \mathrm{H} 31$ & HTF & $14 \mathrm{~A} 10$ & 38.5 & $12.5 \%$ & 10 & 23.4 \\
\hline $10 / 13 / 2006$ & $34 \mathrm{H} 31$ & HTF & 14B10 & 38.5 & $12.5 \%$ & 10 & 23.4 \\
\hline $10 / 13 / 2006$ & $34 \mathrm{H} 31$ & HTF & $14 \mathrm{C} 10$ & 38.5 & $12.5 \%$ & 10 & 23.4 \\
\hline $10 / 19 / 2006$ & $31 \mathrm{G} 66$ & HTF & $15 \mathrm{~A} 9$ & 38.7 & $13.5 \%$ & 9 & 19.3 \\
\hline $10 / 19 / 2006$ & $31 \mathrm{G} 66$ & HTF & $15 \mathrm{~B} 9$ & 38.7 & $13.5 \%$ & 9 & 19.3 \\
\hline $10 / 19 / 2006$ & $31 \mathrm{G} 66$ & HTF & $15 \mathrm{C} 9$ & 38.7 & $13.5 \%$ & 9 & 19.3 \\
\hline $10 / 19 / 2006$ & $31 \mathrm{G} 66$ & HTF & $15 \mathrm{~A} 10$ & 38.7 & $13.5 \%$ & 10 & 19.3 \\
\hline $10 / 19 / 2006$ & $31 \mathrm{G} 66$ & HTF & $15 \mathrm{~B} 10$ & 38.7 & $13.5 \%$ & 10 & 19.3 \\
\hline $10 / 19 / 2006$ & $31 \mathrm{G} 66$ & HTF & $15 \mathrm{C} 10$ & 38.7 & $13.5 \%$ & 10 & 19.3 \\
\hline $10 / 20 / 2006$ & 33M54 & Control & $16 \mathrm{~A} 9$ & 38.3 & $12.5 \%$ & 9 & 25.0 \\
\hline $10 / 20 / 2006$ & 33M54 & Control & $16 \mathrm{~B} 9$ & 38.3 & $12.5 \%$ & 9 & 25.0 \\
\hline $10 / 20 / 2006$ & 33M54 & Control & $16 \mathrm{C} 9$ & 38.3 & $12.5 \%$ & 9 & 25.0 \\
\hline $10 / 20 / 2006$ & 33M54 & Control & $16 \mathrm{~A} 10$ & 38.3 & $12.5 \%$ & 10 & 25.0 \\
\hline $10 / 20 / 2006$ & 33M54 & Control & 16B10 & 38.3 & $12.5 \%$ & 10 & 25.0 \\
\hline $10 / 20 / 2006$ & 33M54 & Control & $16 \mathrm{C} 10$ & 38.3 & $12.5 \%$ & 10 & 25.0 \\
\hline $10 / 20 / 2006$ & 33M54 & Control & $16 \mathrm{~A} 11$ & 38.3 & $12.5 \%$ & 11 & 25.0 \\
\hline $10 / 20 / 2006$ & $33 \mathrm{M} 54$ & Control & 16B11 & 38.3 & $12.5 \%$ & 11 & 25.0 \\
\hline $10 / 20 / 2006$ & 33M54 & Control & $16 \mathrm{C} 11$ & 38.3 & $12.5 \%$ & 11 & 25.0 \\
\hline $10 / 26 / 2006$ & 33 N56 & HTF & 17 A9 & 38.9 & $15.3 \%$ & 9 & 22.4 \\
\hline $10 / 26 / 2006$ & 33 N56 & HTF & 17B9 & 38.9 & $15.3 \%$ & 9 & 22.4 \\
\hline $10 / 26 / 2006$ & 33 N56 & HTF & $17 \mathrm{C} 9$ & 38.9 & $15.3 \%$ & 9 & 22.4 \\
\hline $10 / 26 / 2006$ & 33 N56 & HTF & $17 \mathrm{~A} 10$ & 38.9 & $15.3 \%$ & 10 & 22.4 \\
\hline $10 / 26 / 2006$ & 33 N56 & HTF & $17 \mathrm{~B} 10$ & 38.9 & $15.3 \%$ & 10 & 22.4 \\
\hline $10 / 26 / 2006$ & $33 N 56$ & HTF & $17 \mathrm{C} 10$ & 38.9 & $15.3 \%$ & 10 & 22.4 \\
\hline
\end{tabular}


TABLE IV

RAW CORN PROPERTIES CONT.

\begin{tabular}{|c|c|c|c|c|c|c|c|}
\hline Set Date & Strain & Corn Type & ID & Max Theo $\mathrm{CO}_{2}$ loss & $\%$ Moisture & Cooker \# & Cook Size Theo $(L)$ \\
\hline $10 / 27 / 2006$ & $32 \mathrm{~W} 86$ & Control & 18A9 & 38.5 & $12.3 \%$ & 9 & 25.0 \\
\hline $10 / 27 / 2006$ & $32 \mathrm{~W} 86$ & Control & 18B9 & 38.5 & $12.3 \%$ & 9 & 25.0 \\
\hline $10 / 27 / 2006$ & $32 \mathrm{~W} 86$ & Control & $18 \mathrm{C} 9$ & 38.5 & $12.3 \%$ & 9 & 25.0 \\
\hline \multirow{3}{*}{$\begin{array}{l}10 / 27 / 2006 \\
10 / 27 / 2006 \\
10 / 27 / 2006 \\
\end{array}$} & $32 \mathrm{~W} 86$ & Control & $18 \mathrm{~A} 10$ & 38.5 & $12.3 \%$ & 10 & 25.0 \\
\hline & $32 \mathrm{~W} 86$ & Control & $18 \mathrm{~B} 10$ & 38.5 & $12.3 \%$ & 10 & 25.0 \\
\hline & $32 \mathrm{~W} 86$ & Control & $18 \mathrm{C} 10$ & 38.5 & $12.3 \%$ & 10 & 25.0 \\
\hline \multirow{3}{*}{$\begin{array}{l}10 / 27 / 2006 \\
10 / 27 / 2006 \\
10 / 27 / 2006 \\
\end{array}$} & $32 \mathrm{~W} 86$ & Control & $18 \mathrm{~A} 11$ & 38.5 & $12.3 \%$ & 11 & 25.0 \\
\hline & $32 \mathrm{~W} 86$ & Control & $18 \mathrm{~B} 11$ & 38.5 & $12.3 \%$ & 11 & 25.0 \\
\hline & $32 \mathrm{~W} 86$ & Control & $18 \mathrm{C} 11$ & 38.5 & $12.3 \%$ & 11 & 25.0 \\
\hline \multirow{3}{*}{$\begin{array}{l}11 / 3 / 2006 \\
11 / 3 / 2006 \\
11 / 3 / 2006 \\
\end{array}$} & $34 \mathrm{~A} 15$ & HTF & 19A9 & 38.9 & $13.6 \%$ & 9 & 20.8 \\
\hline & $34 \mathrm{~A} 15$ & HTF & 19B9 & 38.9 & $13.6 \%$ & 9 & 20.8 \\
\hline & $34 \mathrm{~A} 15$ & HTF & $19 \mathrm{C} 9$ & 38.9 & $13.6 \%$ & 9 & 20.8 \\
\hline \multirow{3}{*}{$\begin{array}{l}11 / 3 / 2006 \\
11 / 3 / 2006 \\
11 / 3 / 2006 \\
\end{array}$} & $34 \mathrm{~A} 15$ & HTF & $19 \mathrm{~A} 10$ & 38.9 & $13.6 \%$ & 10 & 20.8 \\
\hline & $34 \mathrm{~A} 15$ & HTF & 19B10 & 38.9 & $13.6 \%$ & 10 & 20.8 \\
\hline & $34 \mathrm{~A} 15$ & HTF & $19 \mathrm{C} 10$ & 38.9 & $13.6 \%$ & 10 & 20.8 \\
\hline \multirow{3}{*}{$\begin{array}{l}11 / 10 / 2006 \\
11 / 10 / 2006 \\
11 / 10 / 2006 \\
\end{array}$} & 33M54 & Control & $20 \mathrm{~A} 9$ & 38.1 & $12.3 \%$ & 9 & 25.0 \\
\hline & 33M54 & Control & $20 \mathrm{~B} 9$ & 38.1 & $12.3 \%$ & 9 & 25.0 \\
\hline & 33M54 & Control & $20 \mathrm{C} 9$ & 38.1 & $12.3 \%$ & 9 & 25.0 \\
\hline \multirow{3}{*}{$\begin{array}{l}11 / 10 / 2006 \\
11 / 10 / 2006 \\
11 / 10 / 2006 \\
\end{array}$} & 33M54 & Control & $20 \mathrm{~A} 10$ & 38.1 & $12.3 \%$ & 10 & 25.0 \\
\hline & 33M54 & Control & $20 \mathrm{~B} 10$ & 38.1 & $12.3 \%$ & 10 & 25.0 \\
\hline & 33M54 & Control & $20 \mathrm{C} 10$ & 38.1 & $12.3 \%$ & 10 & 25.0 \\
\hline \multirow{3}{*}{$\begin{array}{l}11 / 10 / 2006 \\
11 / 10 / 2006 \\
11 / 10 / 2006 \\
\end{array}$} & 33M54 & Control & $20 \mathrm{~A} 11$ & 38.1 & $12.3 \%$ & 11 & 25.0 \\
\hline & 33M54 & Control & $20 \mathrm{~B} 11$ & 38.1 & $12.3 \%$ & 11 & 25.0 \\
\hline & 33M54 & Control & $20 \mathrm{C} 11$ & 38.1 & $12.3 \%$ & 11 & 25.0 \\
\hline \multirow{3}{*}{$\begin{array}{l}11 / 16 / 2006 \\
11 / 16 / 2006 \\
11 / 16 / 2006 \\
\end{array}$} & 34D71 & Control & $21 \mathrm{~A} 9$ & 38.6 & $11.8 \%$ & 9 & 25.0 \\
\hline & $34 \mathrm{D} 71$ & Control & 21B9 & 38.6 & $11.8 \%$ & 9 & 25.0 \\
\hline & $34 \mathrm{D} 71$ & Control & $21 \mathrm{C} 9$ & 38.6 & $11.8 \%$ & 9 & 25.0 \\
\hline \multirow{3}{*}{$\begin{array}{l}11 / 16 / 2006 \\
11 / 16 / 2006 \\
11 / 16 / 2006 \\
\end{array}$} & 34D71 & Control & $21 \mathrm{~A} 10$ & 38.6 & $11.8 \%$ & 10 & 25.0 \\
\hline & $34 \mathrm{D} 71$ & Control & 21B10 & 38.6 & $11.8 \%$ & 10 & 25.0 \\
\hline & $34 \mathrm{D} 71$ & Control & $21 \mathrm{C} 10$ & 38.6 & $11.8 \%$ & 10 & 25.0 \\
\hline \multirow{3}{*}{$\begin{array}{l}11 / 16 / 2006 \\
11 / 16 / 2006 \\
11 / 16 / 2006 \\
\end{array}$} & 34D71 & Control & $21 \mathrm{~A} 11$ & 38.6 & $11.8 \%$ & 11 & 25.0 \\
\hline & 34D71 & Control & 21B11 & 38.6 & $11.8 \%$ & 11 & 25.0 \\
\hline & 34D71 & Control & $21 \mathrm{C} 11$ & 38.6 & $11.8 \%$ & 11 & 25.0 \\
\hline \multirow{3}{*}{$\begin{array}{l}11 / 17 / 2006 \\
11 / 17 / 2006 \\
11 / 17 / 2006 \\
\end{array}$} & 34D71 & Control & $22 \mathrm{~A} 9$ & 38.7 & $12.0 \%$ & 9 & 25.0 \\
\hline & 34D71 & Control & $22 \mathrm{~B} 9$ & 38.7 & $12.0 \%$ & 9 & 25.0 \\
\hline & $34 \mathrm{D} 71$ & Control & $22 \mathrm{C} 9$ & 38.7 & $12.0 \%$ & 9 & 25.0 \\
\hline \multirow{3}{*}{$\begin{array}{l}11 / 17 / 2006 \\
11 / 17 / 2006 \\
11 / 17 / 2006\end{array}$} & $34 \mathrm{D} 71$ & Control & $22 \mathrm{~A} 10$ & 38.7 & $12.0 \%$ & 10 & 25.0 \\
\hline & 34D71 & Control & $22 \mathrm{~B} 10$ & 38.7 & $12.0 \%$ & 10 & 25.0 \\
\hline & 34D71 & Control & $22 \mathrm{C} 10$ & 38.7 & $12.0 \%$ & 10 & 25.0 \\
\hline \multirow{3}{*}{$\begin{array}{l}11 / 17 / 2006 \\
11 / 17 / 2006 \\
11 / 17 / 2006 \\
\end{array}$} & 34D71 & Control & $22 \mathrm{~A} 11$ & 38.7 & $12.0 \%$ & 11 & 25.0 \\
\hline & 34D71 & Control & 22B11 & 38.7 & $12.0 \%$ & 11 & 25.0 \\
\hline & $34 \mathrm{D} 71$ & Control & $22 \mathrm{C} 11$ & 38.7 & $12.0 \%$ & 11 & 25.0 \\
\hline
\end{tabular}




\section{TABLE IV}

RAW CORN PROPERTIES CONT.

\begin{tabular}{|c|c|c|c|c|c|c|c|}
\hline Set Date & Strain & Corn Type & ID & $\begin{array}{c}\text { Max Theo } \\
\mathrm{CO}_{2} \text { loss } \\
\end{array}$ & $\%$ Moisture & \multirow{4}{*}{$\begin{array}{c}\text { Cooker \# } \\
9 \\
9 \\
9 \\
\end{array}$} & \multirow{2}{*}{$\begin{array}{c}\begin{array}{c}\text { Cook Size Theo } \\
(\mathbf{L})\end{array} \\
25.0\end{array}$} \\
\hline \multirow{3}{*}{$\begin{array}{l}11 / 30 / 2006 \\
11 / 30 / 2006 \\
11 / 30 / 2006\end{array}$} & 34D71 & Control & \multirow{3}{*}{$\begin{array}{l}23 \mathrm{~A} 9 \\
23 \mathrm{~B} 9 \\
23 \mathrm{C} 9\end{array}$} & \multirow{3}{*}{$\begin{array}{l}38.7 \\
38.7 \\
38.7 \\
\end{array}$} & \multirow{3}{*}{$\begin{array}{l}11.7 \% \\
11.7 \% \\
11.7 \% \\
\end{array}$} & & \\
\hline & 34D71 & Control & & & & & 25.0 \\
\hline & 34D71 & Control & & & & & 25.0 \\
\hline \multirow{3}{*}{$\begin{array}{l}11 / 30 / 2006 \\
11 / 30 / 2006 \\
11 / 30 / 2006 \\
\end{array}$} & 34D71 & Control & \multirow{3}{*}{$\begin{array}{l}23 \mathrm{~A} 10 \\
23 \mathrm{~B} 10 \\
23 \mathrm{C} 10 \\
\end{array}$} & \multirow{3}{*}{$\begin{array}{l}38.7 \\
38.7 \\
38.7 \\
\end{array}$} & \multirow{3}{*}{$\begin{array}{l}11.7 \% \\
11.7 \% \\
11.7 \% \\
\end{array}$} & \multirow{3}{*}{$\begin{array}{l}10 \\
10 \\
10 \\
\end{array}$} & \multirow{3}{*}{$\begin{array}{r}25.0 \\
25.0 \\
25.0 \\
\end{array}$} \\
\hline & 34D71 & Control & & & & & \\
\hline & 34D71 & Control & & & & & \\
\hline \multirow{3}{*}{$\begin{array}{l}11 / 30 / 2006 \\
11 / 30 / 2006 \\
11 / 30 / 2006 \\
\end{array}$} & $34 \mathrm{D} 71$ & Control & \multirow{3}{*}{$\begin{array}{l}23 \mathrm{~A} 11 \\
23 \mathrm{~B} 11 \\
23 \mathrm{C} 11 \\
\end{array}$} & \multirow{3}{*}{$\begin{array}{l}38.7 \\
38.7 \\
38.7 \\
\end{array}$} & \multirow{3}{*}{$\begin{array}{l}11.7 \% \\
11.7 \% \\
11.7 \% \\
\end{array}$} & \multirow{3}{*}{$\begin{array}{l}11 \\
11 \\
11 \\
\end{array}$} & \multirow{3}{*}{$\begin{array}{l}25.0 \\
25.0 \\
25.0 \\
\end{array}$} \\
\hline & 34D71 & Control & & & & & \\
\hline & 34D71 & Control & & & & & \\
\hline \multirow{3}{*}{$\begin{array}{l}12 / 1 / 2006 \\
12 / 1 / 2006 \\
12 / 1 / 2006 \\
\end{array}$} & $34 \mathrm{D} 71$ & Control & \multirow{3}{*}{$\begin{array}{l}24 \mathrm{~A} 9 \\
24 \mathrm{~B} 9 \\
24 \mathrm{C} 9 \\
\end{array}$} & \multirow{3}{*}{$\begin{array}{l}38.6 \\
38.6 \\
38.6 \\
\end{array}$} & \multirow{3}{*}{$\begin{array}{l}12.0 \% \\
12.0 \% \\
12.0 \% \\
\end{array}$} & \multirow{3}{*}{$\begin{array}{l}9 \\
9 \\
9 \\
\end{array}$} & \multirow{3}{*}{$\begin{array}{l}25.0 \\
25.0 \\
25.0 \\
\end{array}$} \\
\hline & 34D71 & Control & & & & & \\
\hline & 34D71 & Control & & & & & \\
\hline \multirow{3}{*}{$\begin{array}{l}12 / 1 / 2006 \\
12 / 1 / 2006 \\
12 / 1 / 2006 \\
\end{array}$} & $34 \mathrm{D} 71$ & Control & \multirow{3}{*}{$\begin{array}{l}24 \mathrm{~A} 10 \\
24 \mathrm{~B} 10 \\
24 \mathrm{C} 10 \\
\end{array}$} & \multirow{3}{*}{$\begin{array}{l}38.6 \\
38.6 \\
38.6 \\
\end{array}$} & $12.0 \%$ & 10 & 25.0 \\
\hline & $34 \mathrm{D} 71$ & Control & & & $12.0 \%$ & 10 & 25.0 \\
\hline & $34 \mathrm{D} 71$ & Control & & & $12.0 \%$ & 10 & 25.0 \\
\hline $12 / 1 / 2006$ & 34D71 & Control & $24 \mathrm{~A} 11$ & 38.6 & $12.0 \%$ & 11 & 25.0 \\
\hline $12 / 1 / 2006$ & $34 \mathrm{D} 71$ & Control & $24 \mathrm{~B} 11$ & 38.6 & $12.0 \%$ & 11 & 25.0 \\
\hline $12 / 1 / 2006$ & 34D71 & Control & $24 \mathrm{C} 11$ & 38.6 & $12.0 \%$ & 11 & 25.0 \\
\hline $12 / 7 / 2006$ & $34 \mathrm{D} 71$ & Control & $25 \mathrm{~A} 9$ & 38.7 & $11.7 \%$ & 9 & 25.0 \\
\hline $12 / 7 / 2006$ & 34D71 & Control & $25 \mathrm{~B} 9$ & 38.7 & $11.7 \%$ & 9 & 25.0 \\
\hline $12 / 7 / 2006$ & 34D71 & Control & $25 \mathrm{C} 9$ & 38.7 & $11.7 \%$ & 9 & 25.0 \\
\hline $12 / 7 / 2006$ & 34D71 & Control & $25 \mathrm{~A} 10$ & 38.7 & $11.7 \%$ & 10 & 25.0 \\
\hline $12 / 7 / 2006$ & $34 \mathrm{D} 71$ & Control & $25 \mathrm{~B} 10$ & 38.7 & $11.7 \%$ & 10 & 25.0 \\
\hline $12 / 7 / 2006$ & $34 \mathrm{D} 71$ & Control & $25 \mathrm{C} 10$ & 38.7 & $11.7 \%$ & 10 & 25.0 \\
\hline $12 / 7 / 2006$ & 34D71 & Control & $25 \mathrm{~A} 11$ & 38.7 & $11.7 \%$ & 11 & 25.0 \\
\hline $12 / 7 / 2006$ & $34 \mathrm{D} 71$ & Control & $25 \mathrm{~B} 11$ & 38.7 & $11.7 \%$ & 11 & 25.0 \\
\hline $12 / 7 / 2006$ & $34 \mathrm{D} 71$ & Control & $25 \mathrm{C} 11$ & 38.7 & $11.7 \%$ & 11 & 25.0 \\
\hline $12 / 8 / 2006$ & 34D71 & Control & $26 \mathrm{~A} 9$ & 38.5 & $11.9 \%$ & 9 & 25.0 \\
\hline $12 / 8 / 2006$ & 34D71 & Control & 26B9 & 38.5 & $11.9 \%$ & 9 & 25.0 \\
\hline $12 / 8 / 2006$ & $34 \mathrm{D} 71$ & Control & $26 \mathrm{C} 9$ & 38.5 & $11.9 \%$ & 9 & 25.0 \\
\hline $12 / 8 / 2006$ & $34 \mathrm{D} 71$ & Control & $26 \mathrm{~A} 10$ & 38.5 & $11.9 \%$ & 10 & 25.0 \\
\hline $12 / 8 / 2006$ & 34D71 & Control & 26B10 & 38.5 & $11.9 \%$ & 10 & 25.0 \\
\hline $12 / 8 / 2006$ & 34D71 & Control & $26 \mathrm{C} 10$ & 38.5 & $11.9 \%$ & 10 & 25.0 \\
\hline $12 / 8 / 2006$ & $34 \mathrm{D} 71$ & Control & $26 \mathrm{~A} 11$ & 38.5 & $11.9 \%$ & 11 & 25.0 \\
\hline $12 / 8 / 2006$ & $34 \mathrm{D} 71$ & Control & 26B11 & 38.5 & $11.9 \%$ & 11 & 25.0 \\
\hline $12 / 8 / 2006$ & $34 \mathrm{D} 71$ & Control & $26 \mathrm{C} 11$ & 38.5 & $11.9 \%$ & 11 & 25.0 \\
\hline
\end{tabular}


TABLE IV

RAW CORN PROPERTIES CONT.

\begin{tabular}{|c|c|c|c|c|c|c|c|}
\hline Set Date & Strain & Corn Type & ID & $\begin{array}{c}\text { Max Theo } \\
\mathrm{CO}_{2} \text { loss } \\
\end{array}$ & $\%$ Moisture & Cooker \# & $\begin{array}{l}\text { Cook Size } \\
\text { Theo (L) } \\
\end{array}$ \\
\hline $12 / 14 / 2006$ & 34D71 & Control & 27A9 & 38.5 & $11.8 \%$ & 9 & 25.0 \\
\hline $12 / 14 / 2006$ & 34D71 & Control & 27B9 & 38.5 & $11.8 \%$ & 9 & 25.0 \\
\hline $12 / 14 / 2006$ & 34D71 & Control & $27 \mathrm{C} 9$ & 38.5 & $11.8 \%$ & 9 & 25.0 \\
\hline $12 / 14 / 2006$ & 34D71 & Control & $27 \mathrm{~A} 10$ & 38.5 & $11.8 \%$ & 10 & 25.0 \\
\hline $12 / 14 / 2006$ & 34D71 & Control & $27 \mathrm{~B} 10$ & 38.5 & $11.8 \%$ & 10 & 25.0 \\
\hline $12 / 14 / 2006$ & 34D71 & Control & $27 \mathrm{C} 10$ & 38.5 & $11.8 \%$ & 10 & 25.0 \\
\hline $12 / 14 / 2006$ & 34D71 & Control & $27 \mathrm{~A} 11$ & 38.5 & $11.8 \%$ & 11 & 25.0 \\
\hline $12 / 14 / 2006$ & 34D71 & Control & $27 \mathrm{~B} 11$ & 38.5 & $11.8 \%$ & 11 & 25.0 \\
\hline $12 / 14 / 2006$ & 34D71 & Control & $27 \mathrm{C} 11$ & 38.5 & $11.8 \%$ & 11 & 25.0 \\
\hline $12 / 15 / 2006$ & 34D71 & Control & 28A9 & 38.7 & $11.5 \%$ & 9 & 25.0 \\
\hline $12 / 15 / 2006$ & 34D71 & Control & $28 \mathrm{~B} 9$ & 38.7 & $11.5 \%$ & 9 & 25.0 \\
\hline $12 / 15 / 2006$ & 34D71 & Control & $28 \mathrm{C} 9$ & 38.7 & $11.5 \%$ & 9 & 25.0 \\
\hline $12 / 15 / 2006$ & 34D71 & Control & $28 \mathrm{~A} 10$ & 38.7 & $11.5 \%$ & 10 & 25.0 \\
\hline $12 / 15 / 2006$ & 34D71 & Control & $28 \mathrm{~B} 10$ & 38.7 & $11.5 \%$ & 10 & 25.0 \\
\hline $12 / 15 / 2006$ & 34D71 & Control & $28 \mathrm{C} 10$ & 38.7 & $11.5 \%$ & 10 & 25.0 \\
\hline $12 / 15 / 2006$ & 34D71 & Control & $28 \mathrm{~A} 11$ & 38.7 & $11.5 \%$ & 11 & 25.0 \\
\hline $12 / 15 / 2006$ & 34D71 & Control & 28B11 & 38.7 & $11.5 \%$ & 11 & 25.0 \\
\hline $12 / 15 / 2006$ & 34D71 & Control & $28 \mathrm{C} 11$ & 38.7 & $11.5 \%$ & 11 & 25.0 \\
\hline
\end{tabular}


TABLE V

SET DATA

\begin{tabular}{|c|c|c|c|c|c|c|c|c|}
\hline ID & $\begin{array}{c}\text { Cook Size } \\
\text { Actual (L) } \\
\end{array}$ & Set pH & $\begin{array}{c}\text { Set } \\
\text { Balling } \\
(\%) \\
\end{array}$ & $\begin{array}{c}\text { Nalgene wt } \\
(\mathrm{g})\end{array}$ & $\begin{array}{c}\text { Total wt w/ } \\
\text { yeast }(\mathbf{g}) \\
\end{array}$ & $\begin{array}{c}\text { Total set } \\
\text { wt (g) } \\
\end{array}$ & $\begin{array}{c}\text { Mash wt } \\
(\mathrm{g}) \\
\end{array}$ & $\begin{array}{c}\text { g dry corn } \\
\text { mashed }\end{array}$ \\
\hline $1 \mathrm{~A} 9$ & 22.6 & 5.78 & 19.5 & 310 & 448 & 3727 & 3279 & 676 \\
\hline 1B9 & 22.6 & 5.78 & 19.5 & 312 & 452 & 3718 & 3266 & 673 \\
\hline $1 \mathrm{C} 9$ & 22.6 & 5.78 & 19.5 & 313 & 445 & 3463 & 3018 & 622 \\
\hline $1 \mathrm{~A} 10$ & 22.6 & 5.81 & 19.5 & 312 & 451 & 3543 & 3092 & 638 \\
\hline $1 \mathrm{~B} 10$ & 22.6 & 5.81 & 19.5 & 312 & 456 & 3616 & 3160 & 652 \\
\hline $1 \mathrm{C} 10$ & 22.6 & 5.81 & 19.5 & 312 & 455 & 3746 & 3291 & 679 \\
\hline 2A9 & 23.6 & 5.74 & 18.9 & 314 & 453 & 3558 & 3105 & 628 \\
\hline 2B9 & 23.6 & 5.74 & 18.9 & 313 & 452 & 3607 & 3155 & 639 \\
\hline 2C9 & 23.6 & 5.74 & 18.9 & 312 & 451 & 3636 & 3185 & 645 \\
\hline $2 \mathrm{~A} 10$ & 23.6 & 5.72 & 18.3 & 312 & 451 & 3575 & 3124 & 632 \\
\hline $2 \mathrm{~B} 10$ & 23.6 & 5.72 & 18.3 & 315 & 453 & 3818 & 3365 & 681 \\
\hline $2 \mathrm{C} 10$ & 23.6 & 5.72 & 18.3 & 315 & 450 & 3649 & 3199 & 648 \\
\hline $3 \mathrm{~A} 9$ & 18.2 & 5.94 & 20.1 & 312 & 444 & 3545 & 3101 & 629 \\
\hline $3 \mathrm{~B} 9$ & 18.2 & 5.94 & 20.1 & 314 & 456 & 3552 & 3096 & 628 \\
\hline $3 \mathrm{C} 9$ & 18.2 & 5.94 & 20.1 & 314 & 443 & 3493 & 3050 & 619 \\
\hline $3 \mathrm{~A} 10$ & 20.9 & 5.94 & 19.2 & 313 & 453 & 3411 & 2958 & 600 \\
\hline $3 \mathrm{~B} 10$ & 20.9 & 5.94 & 19.2 & 314 & 453 & 3647 & 3194 & 648 \\
\hline $3 \mathrm{C} 10$ & 20.9 & 5.94 & 19.2 & 314 & 456 & 3646 & 3190 & 647 \\
\hline 4A9 & 23.7 & 5.78 & 18.9 & 311 & 446 & 3583 & 3137 & 636 \\
\hline 4B9 & 23.7 & 5.78 & 18.9 & 312 & 450 & 3617 & 3167 & 643 \\
\hline 4C9 & 23.7 & 5.78 & 18.9 & 312 & 446 & 3649 & 3203 & 650 \\
\hline $4 \mathrm{~A} 10$ & 23.7 & 5.78 & 19.5 & 311 & 451 & 3487 & 3036 & 616 \\
\hline $4 \mathrm{~B} 10$ & 23.7 & 5.78 & 19.5 & 316 & 456 & 3598 & 3142 & 637 \\
\hline 5A9 & 22.7 & 5.88 & 17.7 & 312 & 461 & 3758 & 3297 & 674 \\
\hline $5 B 9$ & 22.7 & 5.88 & 17.7 & 314 & 454 & 3667 & 3213 & 656 \\
\hline $5 \mathrm{C} 9$ & 22.7 & 5.88 & 17.7 & 314 & 454 & 3674 & 3220 & 658 \\
\hline $5 \mathrm{~A} 10$ & 22.7 & 5.91 & 17.7 & 313 & 465 & 3585 & 3120 & 637 \\
\hline $5 \mathrm{~B} 10$ & 22.7 & 5.91 & 17.7 & 314 & 464 & 3601 & 3137 & 641 \\
\hline $5 \mathrm{C} 10$ & 22.7 & 5.91 & 17.7 & 314 & 474 & 3722 & 3248 & 664 \\
\hline 6A9 & 24.6 & 5.84 & 18.0 & 313 & 453 & 3595 & 3142 & 641 \\
\hline $6 \mathrm{~B} 9$ & 24.6 & 5.84 & 18.0 & 310 & 450 & 3664 & 3214 & 656 \\
\hline $6 \mathrm{C} 9$ & 24.6 & 5.84 & 18.0 & 312 & 449 & 3443 & 2994 & 611 \\
\hline $6 \mathrm{~A} 10$ & 24.6 & 5.82 & 17.7 & 312 & 449 & 3597 & 3148 & 642 \\
\hline $6 \mathrm{~B} 10$ & 24.6 & 5.82 & 17.7 & 313 & 455 & 3612 & 3157 & 644 \\
\hline $6 \mathrm{C} 10$ & 24.6 & 5.82 & 17.7 & 312 & 447 & 3692 & 3245 & 662 \\
\hline $6 \mathrm{~A} 11$ & 24.6 & 5.83 & 18.6 & 312 & 453 & 3600 & 3147 & 642 \\
\hline $6 \mathrm{~B} 11$ & 24.6 & 5.83 & 18.6 & 313 & 448 & 3429 & 2981 & 608 \\
\hline $6 \mathrm{C} 11$ & 24.6 & 5.83 & 18.6 & 315 & 454 & 3547 & 3093 & 631 \\
\hline
\end{tabular}


TABLE V

SET DATA CONT.

\begin{tabular}{|c|c|c|c|c|c|c|c|c|}
\hline ID & $\begin{array}{l}\text { Cook Size } \\
\text { Actual (L) } \\
\end{array}$ & Set pH & $\begin{array}{c}\text { Set Balling } \\
(\%) \\
\end{array}$ & $\begin{array}{c}\text { Nalgene } \\
\text { wt (g) } \\
\end{array}$ & $\begin{array}{c}\text { Total wt } \\
\text { w/ yeast } \\
\text { (g) } \\
\end{array}$ & $\begin{array}{c}\text { Total set } \\
\text { wt (g) } \\
\end{array}$ & $\begin{array}{c}\text { Mash wt } \\
(\mathrm{g}) \\
\end{array}$ & $\begin{array}{c}\text { g dry corn } \\
\text { mashed }\end{array}$ \\
\hline 7A9 & 25.8 & 5.85 & 18.3 & 315 & 456 & 3542 & 3086 & 641 \\
\hline $7 \mathrm{~B} 9$ & 25.8 & 5.85 & 18.3 & 312 & 449 & 3496 & 3047 & 633 \\
\hline 7C9 & 25.8 & 5.85 & 18.3 & 313 & 452 & 3604 & 3152 & 655 \\
\hline 7A10 & 25.0 & 5.90 & 17.1 & 313 & 447 & 3581 & 3134 & 651 \\
\hline 7B10 & 25.0 & 5.90 & 17.1 & 312 & 452 & 3574 & 3122 & 648 \\
\hline 7C10 & 25.0 & 5.90 & 17.1 & 313 & 456 & 3743 & 3287 & 683 \\
\hline 7A11 & 23.9 & 5.91 & 17.7 & 313 & 453 & 3639 & 3186 & 662 \\
\hline 7B11 & 23.9 & 5.91 & 17.7 & 316 & 457 & 3551 & 3094 & 642 \\
\hline 7C11 & 23.9 & 5.91 & 17.7 & 314 & 451 & 3705 & 3254 & 676 \\
\hline $8 \mathrm{~A} 9$ & 25.4 & 5.91 & 17.4 & 314 & 455 & 3640 & 3185 & 662 \\
\hline $8 B 9$ & 25.4 & 5.91 & 17.4 & 311 & 457 & 3367 & 2910 & 605 \\
\hline $8 \mathrm{C} 9$ & 25.4 & 5.91 & 17.4 & 314 & 454 & 3615 & 3161 & 657 \\
\hline 8A10 & 24.6 & 5.86 & 17.1 & 315 & 457 & 3477 & 3020 & 628 \\
\hline 8B10 & 24.6 & 5.86 & 17.1 & 311 & 455 & 3608 & 3153 & 655 \\
\hline $8 \mathrm{C} 10$ & 24.6 & 5.86 & 17.1 & 311 & 451 & 3553 & 3102 & 645 \\
\hline 8A11 & 25.8 & 5.92 & 16.8 & 313 & 457 & 3557 & 3100 & 644 \\
\hline 8B11 & 25.8 & 5.92 & 16.8 & 315 & 459 & 3379 & 2920 & 607 \\
\hline $8 \mathrm{C} 11$ & 25.8 & 5.92 & 16.8 & 315 & 456 & 3419 & 2963 & 616 \\
\hline 9A9 & 24.6 & 5.87 & 17.7 & 312 & 451 & 3364 & 2913 & 607 \\
\hline 9B9 & 24.6 & 5.87 & 17.7 & 313 & 454 & 3620 & 3166 & 660 \\
\hline 9C9 & 24.6 & 5.87 & 17.7 & 314 & 456 & 3626 & 3170 & 661 \\
\hline 9A10 & 25.4 & 5.83 & 18.0 & 312 & 448 & 3439 & 2991 & 623 \\
\hline 9B10 & 25.4 & 5.83 & 18.0 & 313 & 457 & 3515 & 3058 & 637 \\
\hline $9 \mathrm{C} 10$ & 25.4 & 5.83 & 18.0 & 312 & 456 & 3479 & 3023 & 630 \\
\hline 9A11 & 25.0 & 5.96 & 17.7 & 315 & 460 & 3697 & 3237 & 675 \\
\hline 9B11 & 25.0 & 5.96 & 17.7 & 313 & 455 & 3747 & 3292 & 686 \\
\hline $9 \mathrm{C} 11$ & 25.0 & 5.96 & 17.7 & 313 & 456 & 3853 & 3397 & 708 \\
\hline 10A9 & 24.6 & 5.98 & 19.2 & 314 & 450 & 3674 & 3224 & 668 \\
\hline 10B9 & 24.6 & 5.98 & 19.2 & 314 & 462 & 3495 & 3033 & 628 \\
\hline 10C9 & 24.6 & 5.98 & 19.2 & 310 & 452 & 3696 & 3244 & 672 \\
\hline 10A10 & 24.6 & 5.99 & 18.3 & 315 & 455 & 3466 & 3011 & 624 \\
\hline 10B10 & 24.6 & 5.99 & 18.3 & 313 & 454 & 3696 & 3242 & 672 \\
\hline $10 \mathrm{C} 10$ & 24.6 & 5.99 & 18.3 & 314 & 453 & 3606 & 3153 & 653 \\
\hline 10A11 & 24.6 & 5.98 & 18.3 & 312 & 459 & 3737 & 3278 & 679 \\
\hline 10B11 & 24.6 & 5.98 & 18.3 & 317 & 461 & 3718 & 3257 & 675 \\
\hline $10 \mathrm{C} 11$ & 24.6 & 5.98 & 18.3 & 313 & 452 & 3593 & 3141 & 651 \\
\hline $11 \mathrm{~A} 9$ & 20.5 & 5.75 & 18.0 & 314 & 446 & 3613 & 3167 & 648 \\
\hline 11B9 & 20.5 & 5.75 & 18.0 & 314 & 447 & 3665 & 3218 & 659 \\
\hline $11 \mathrm{C} 9$ & 20.5 & 5.75 & 18.0 & 314 & 444 & 3506 & 3062 & 627 \\
\hline 11A10 & 19.3 & 5.77 & 18.6 & 314 & 449 & 3519 & 3070 & 629 \\
\hline 11B10 & 19.3 & 5.77 & 18.6 & 312 & 453 & 3674 & 3221 & 660 \\
\hline $11 \mathrm{C} 10$ & 19.3 & 5.77 & 18.6 & 313 & 447 & 3529 & 3082 & 631 \\
\hline
\end{tabular}


TABLE V

SET DATA CONT.

\begin{tabular}{|c|c|c|c|c|c|c|c|c|}
\hline ID & $\begin{array}{l}\text { Cook Size } \\
\text { Actual (L) } \\
\end{array}$ & Set pH & $\begin{array}{c}\text { Set Balling } \\
(\%) \\
\end{array}$ & $\begin{array}{c}\text { Nalgene } \\
\text { wt (g) } \\
\end{array}$ & $\begin{array}{c}\text { Total wt } \\
\text { w/ yeast } \\
\text { (g) } \\
\end{array}$ & $\begin{array}{c}\text { Total set } \\
\text { wt (g) }\end{array}$ & $\begin{array}{c}\text { Mash wt } \\
(\mathrm{g}) \\
\end{array}$ & $\begin{array}{c}\text { g dry corn } \\
\text { mashed }\end{array}$ \\
\hline $12 \mathrm{~A} 9$ & 20.3 & 5.81 & 18.6 & 314 & 459 & 3586 & 3127 & 638 \\
\hline $12 \mathrm{~B} 9$ & 20.3 & 5.81 & 18.6 & 313 & 457 & 3546 & 3089 & 630 \\
\hline $12 \mathrm{C} 9$ & 20.3 & 5.81 & 18.6 & 314 & 462 & 3580 & 3118 & 636 \\
\hline $12 \mathrm{~A} 10$ & 20.7 & 5.81 & 18.6 & 314 & 460 & 3714 & 3254 & 664 \\
\hline 12B10 & 20.7 & 5.81 & 18.6 & 312 & 449 & 3284 & 2835 & 578 \\
\hline $12 \mathrm{C} 10$ & 20.7 & 5.81 & 18.6 & 315 & 457 & 3659 & 3202 & 653 \\
\hline $13 \mathrm{~A} 9$ & 24.6 & 6.13 & 16.5 & 315 & 458 & 3600 & 3142 & 643 \\
\hline $13 \mathrm{~B} 9$ & 24.6 & 6.13 & 16.5 & 313 & 451 & 3497 & 3046 & 624 \\
\hline $13 \mathrm{C} 9$ & 24.6 & 6.13 & 16.5 & 314 & 453 & 3763 & 3310 & 678 \\
\hline 13A10 & 25.4 & 6.12 & 15.9 & 314 & 463 & 3616 & 3153 & 646 \\
\hline 13B10 & 25.4 & 6.12 & 15.9 & 316 & 461 & 3277 & 2816 & 577 \\
\hline $13 \mathrm{C} 10$ & 25.4 & 6.12 & 15.9 & 316 & 459 & 3325 & 2866 & 587 \\
\hline 13A11 & 25.0 & 5.95 & 18.0 & 313 & 453 & 3715 & 3262 & 668 \\
\hline 13B11 & 25.0 & 5.95 & 18.0 & 313 & 460 & 3764 & 3304 & 677 \\
\hline $13 \mathrm{C} 11$ & 25.0 & 5.95 & 18.0 & 313 & 458 & 3542 & 3084 & 631 \\
\hline $14 \mathrm{~A} 9$ & 23.9 & 6.00 & 18.3 & 312 & 462 & 3451 & 2989 & 603 \\
\hline $14 \mathrm{~B} 9$ & 23.9 & 6.00 & 18.3 & 314 & 447 & 3693 & 3246 & 655 \\
\hline $14 \mathrm{C} 9$ & 23.9 & 6.00 & 18.3 & 313 & 459 & 3600 & 3141 & 634 \\
\hline 14A10 & 23.3 & 5.85 & 18.3 & 312 & 454 & 3451 & 2997 & 605 \\
\hline 14B10 & 23.3 & 5.85 & 18.3 & 313 & 462 & 3608 & 3146 & 635 \\
\hline $14 \mathrm{C} 10$ & 23.3 & 5.85 & 18.3 & 314 & 460 & 3535 & 3075 & 620 \\
\hline $15 \mathrm{~A} 9$ & 20.1 & 5.81 & 17.1 & 314 & 458 & 3510 & 3052 & 623 \\
\hline $15 \mathrm{~B} 9$ & 20.1 & 5.81 & 17.1 & 314 & 460 & 3643 & 3183 & 649 \\
\hline $15 \mathrm{C} 9$ & 20.1 & 5.81 & 17.1 & 316 & 462 & 3800 & 3338 & 681 \\
\hline 15A10 & 16.3 & 5.82 & 16.5 & 315 & 456 & 3403 & 2947 & 601 \\
\hline 15B10 & 16.3 & 5.82 & 16.5 & 312 & 460 & 3624 & 3164 & 646 \\
\hline $15 \mathrm{C} 10$ & 16.3 & 5.82 & 16.5 & 314 & 460 & 3662 & 3202 & 653 \\
\hline 16A9 & 25.2 & 6.08 & 18.9 & 314 & 454 & 3546 & 3092 & 624 \\
\hline $16 \mathrm{~B} 9$ & 25.2 & 6.08 & 18.9 & 315 & 466 & 3356 & 2890 & 583 \\
\hline $16 \mathrm{C} 9$ & 25.2 & 6.08 & 18.9 & 314 & 448 & 3497 & 3049 & 615 \\
\hline 16A10 & 24.9 & 6.08 & 18.9 & 313 & 451 & 3555 & 3104 & 626 \\
\hline 16B10 & 24.9 & 6.08 & 18.9 & 314 & 453 & 3594 & 3141 & 634 \\
\hline $16 \mathrm{C} 10$ & 24.9 & 6.08 & 18.9 & 315 & 448 & 3632 & 3184 & 642 \\
\hline 16A11 & 25.0 & 6.08 & 18.9 & 314 & 452 & 3577 & 3125 & 630 \\
\hline 16B11 & 25.0 & 6.08 & 18.9 & 313 & 458 & 3821 & 3363 & 678 \\
\hline $16 \mathrm{C} 11$ & 25.0 & 6.08 & 18.9 & 314 & 446 & 3593 & 3147 & 635 \\
\hline 17A9 & 22.6 & 5.73 & 19.2 & 313 & 447 & 3551 & 3104 & 647 \\
\hline 17B9 & 22.6 & 5.73 & 19.2 & 313 & 459 & 3506 & 3047 & 635 \\
\hline $17 \mathrm{C} 9$ & 22.6 & 5.73 & 19.2 & 315 & 451 & 3537 & 3086 & 643 \\
\hline 17A10 & 21.8 & 5.80 & 18.9 & 314 & 448 & 3611 & 3163 & 659 \\
\hline 17B10 & 21.8 & 5.80 & 18.9 & 314 & 454 & 3730 & 3276 & 683 \\
\hline $17 \mathrm{C} 10$ & 21.8 & 5.80 & 18.9 & 311 & 458 & 3722 & 3264 & 680 \\
\hline
\end{tabular}


TABLE V

SET DATA CONT.

\begin{tabular}{|c|c|c|c|c|c|c|c|c|}
\hline ID & $\begin{array}{l}\text { Cook Size } \\
\text { Actual (L) } \\
\end{array}$ & Set pH & $\begin{array}{c}\text { Set } \\
\text { Balling } \\
(\%) \\
\end{array}$ & $\begin{array}{c}\text { Nalgene wt } \\
(\mathrm{g}) \\
\end{array}$ & $\begin{array}{c}\text { Total wt w/ } \\
\text { yeast }(g)\end{array}$ & $\begin{array}{c}\text { Total set } \\
\text { wt (g) } \\
\end{array}$ & $\begin{array}{c}\text { Mash wt } \\
(\mathrm{g}) \\
\end{array}$ & $\begin{array}{c}\text { g dry corn } \\
\text { mashed }\end{array}$ \\
\hline $18 \mathrm{~A} 9$ & 24.6 & 5.92 & 19.2 & 313 & 449 & 3702 & 3253 & 655 \\
\hline 18B9 & 24.6 & 5.92 & 19.2 & 313 & 458 & 3570 & 3112 & 626 \\
\hline $18 \mathrm{C} 9$ & 24.6 & 5.92 & 19.2 & 315 & 456 & 3446 & 2990 & 602 \\
\hline 18A10 & 25.0 & 5.91 & 18.6 & 314 & 449 & 3369 & 2920 & 588 \\
\hline 18B10 & 25.0 & 5.91 & 18.6 & 314 & 451 & 3522 & 3071 & 618 \\
\hline $18 \mathrm{C} 10$ & 25.0 & 5.91 & 18.6 & 315 & 461 & 3592 & 3131 & 630 \\
\hline 18A11 & 24.6 & 5.93 & 18.3 & 313 & 461 & 3323 & 2862 & 576 \\
\hline 18B11 & 24.6 & 5.93 & 18.3 & 316 & 459 & 3354 & 2895 & 583 \\
\hline $18 \mathrm{C} 11$ & 24.6 & 5.93 & 18.3 & 313 & 451 & 3673 & 3222 & 648 \\
\hline 19A9 & 20.5 & 5.94 & 18.9 & 313 & 461 & 3370 & 2909 & 594 \\
\hline 19B9 & 20.5 & 5.94 & 18.9 & 313 & 451 & 3663 & 3212 & 656 \\
\hline $19 \mathrm{C} 9$ & 20.5 & 5.94 & 18.9 & 313 & 451 & 3656 & 3205 & 655 \\
\hline 19A10 & 20.5 & 5.96 & 19.8 & 313 & 451 & 3456 & 3005 & 614 \\
\hline 19B10 & 20.5 & 5.96 & 19.8 & 316 & 453 & 3599 & 3146 & 643 \\
\hline $19 \mathrm{C} 10$ & 20.5 & 5.96 & 19.8 & 311 & 454 & 3714 & 3260 & 666 \\
\hline 20A9 & 23.7 & 6.03 & 19.8 & 312 & 448 & 3551 & 3103 & 624 \\
\hline $20 B 9$ & 23.7 & 6.03 & 19.8 & 313 & 448 & 3369 & 2921 & 588 \\
\hline 20C9 & 23.7 & 6.03 & 19.8 & 314 & 455 & 3568 & 3113 & 627 \\
\hline $20 \mathrm{~A} 10$ & 24.6 & 5.99 & 18.6 & 314 & 458 & 3606 & 3148 & 634 \\
\hline $20 \mathrm{~B} 10$ & 24.6 & 5.99 & 18.6 & 313 & 454 & 3444 & 2990 & 602 \\
\hline $20 \mathrm{C} 10$ & 24.6 & 5.99 & 18.6 & 314 & 462 & 3660 & 3198 & 644 \\
\hline $20 \mathrm{~A} 11$ & 24.3 & 6.05 & 18.6 & 314 & 446 & 3588 & 3142 & 632 \\
\hline $20 \mathrm{~B} 11$ & 24.3 & 6.05 & 18.6 & 313 & 454 & 3425 & 2971 & 598 \\
\hline $20 \mathrm{C} 11$ & 24.3 & 6.05 & 18.6 & 313 & 455 & 3548 & 3093 & 622 \\
\hline $21 \mathrm{~A} 9$ & 24.6 & 5.93 & 18.9 & 314 & 453 & 3591 & 3138 & 628 \\
\hline $21 \mathrm{~B} 9$ & 24.6 & 5.93 & 18.9 & 313 & 460 & 3611 & 3151 & 631 \\
\hline $21 \mathrm{C} 9$ & 24.6 & 5.93 & 18.9 & 316 & 458 & 3346 & 2888 & 578 \\
\hline 21A10 & 25.8 & 5.91 & 18.6 & 311 & 458 & 3729 & 3271 & 655 \\
\hline 21B10 & 25.8 & 5.91 & 18.6 & 314 & 455 & 3591 & 3136 & 628 \\
\hline $21 \mathrm{C} 10$ & 25.8 & 5.91 & 18.6 & 313 & 460 & 3605 & 3145 & 629 \\
\hline 21A11 & 25.0 & 5.98 & 18.3 & 312 & 452 & 3536 & 3084 & 617 \\
\hline 21B11 & 25.0 & 5.98 & 18.3 & 313 & 457 & 3566 & 3109 & 622 \\
\hline $21 \mathrm{C} 11$ & 25.0 & 5.98 & 18.3 & 313 & 453 & 3817 & 3364 & 673 \\
\hline 22A9 & 24.3 & 5.87 & 18.9 & 316 & 454 & 3571 & 3117 & 625 \\
\hline $22 \mathrm{~B} 9$ & 24.3 & 5.87 & 18.9 & 313 & 459 & 3751 & 3292 & 660 \\
\hline $22 \mathrm{C} 9$ & 24.3 & 5.87 & 18.9 & 314 & 457 & 3772 & 3315 & 665 \\
\hline 22A10 & 26.1 & 5.90 & 18.3 & 314 & 457 & 3419 & 2962 & 594 \\
\hline $22 \mathrm{~B} 10$ & 26.1 & 5.90 & 18.3 & 313 & 458 & 3675 & 3217 & 645 \\
\hline $22 \mathrm{C} 10$ & 26.1 & 5.90 & 18.3 & 312 & 456 & 3423 & 2967 & 595 \\
\hline 22A11 & 24.6 & 5.93 & 18.6 & 313 & 453 & 3548 & 3095 & 621 \\
\hline 22B11 & 24.6 & 5.93 & 18.6 & 316 & 456 & 3468 & 3012 & 604 \\
\hline $22 \mathrm{C} 11$ & 24.6 & 5.93 & 18.6 & 316 & 457 & 3688 & 3231 & 648 \\
\hline
\end{tabular}


TABLE V

SET DATA CONT.

\begin{tabular}{|c|c|c|c|c|c|c|c|c|}
\hline ID & $\begin{array}{c}\text { Cook Size } \\
\text { Actual (L) } \\
\end{array}$ & Set pH & $\begin{array}{c}\text { Set Balling } \\
(\%)\end{array}$ & $\begin{array}{c}\text { Nalgene } \\
\text { wt (g) } \\
\end{array}$ & $\begin{array}{c}\text { Total wt } \\
\text { w/ yeast } \\
\text { (g) }\end{array}$ & $\begin{array}{c}\text { Total set } \\
\text { wt (g) }\end{array}$ & $\begin{array}{c}\text { Mash wt } \\
(\mathrm{g}) \\
\end{array}$ & $\begin{array}{c}\text { g dry corn } \\
\text { mashed }\end{array}$ \\
\hline 23A9 & 25.6 & 5.94 & 18.9 & 311 & 462 & 3481 & 3019 & 603 \\
\hline 23B9 & 25.6 & 5.94 & 18.9 & 316 & 457 & 3532 & 3075 & 615 \\
\hline $23 \mathrm{C} 9$ & 25.6 & 5.94 & 18.9 & 313 & 451 & 3522 & 3071 & 614 \\
\hline $23 \mathrm{~A} 10$ & 25.4 & 5.99 & 17.7 & 312 & 459 & 3487 & 3028 & 605 \\
\hline $23 \mathrm{~B} 10$ & 25.4 & 5.99 & 17.7 & 313 & 456 & 3569 & 3113 & 622 \\
\hline $23 \mathrm{C} 10$ & 25.4 & 5.99 & 17.7 & 315 & 456 & 3392 & 2936 & 587 \\
\hline $23 \mathrm{~A} 11$ & 24.6 & 6.03 & 18.6 & 312 & 455 & 3664 & 3209 & 641 \\
\hline $23 \mathrm{~B} 11$ & 24.6 & 6.03 & 18.6 & 315 & 458 & 3628 & 3170 & 634 \\
\hline $23 \mathrm{C} 11$ & 24.6 & 6.03 & 18.6 & 313 & 456 & 3883 & 3427 & 685 \\
\hline 24A9 & 24.5 & 5.93 & 19.2 & 313 & 457 & 3641 & 3184 & 639 \\
\hline $24 \mathrm{~B} 9$ & 24.5 & 5.93 & 19.2 & 313 & 458 & 3530 & 3072 & 616 \\
\hline 24C9 & 24.5 & 5.93 & 19.2 & 314 & 456 & 3688 & 3232 & 648 \\
\hline $24 \mathrm{~A} 10$ & 26.2 & 5.97 & 18.3 & 315 & 458 & 3417 & 2959 & 593 \\
\hline $24 \mathrm{~B} 10$ & 26.2 & 5.97 & 18.3 & 313 & 457 & 3431 & 2974 & 596 \\
\hline $24 \mathrm{C} 10$ & 26.2 & 5.97 & 18.3 & 315 & 466 & 3519 & 3053 & 612 \\
\hline $24 \mathrm{~A} 11$ & 25.6 & 6.00 & 18.0 & 311 & 453 & 3749 & 3296 & 661 \\
\hline 24B11 & 25.6 & 6.00 & 18.0 & 314 & 457 & 3702 & 3245 & 651 \\
\hline $24 \mathrm{C} 11$ & 25.6 & 6.00 & 18.0 & 314 & 457 & 3639 & 3182 & 638 \\
\hline 25A9 & 25.0 & 6.05 & 18.6 & 313 & 454 & 3416 & 2962 & 592 \\
\hline $25 \mathrm{~B} 9$ & 25.0 & 6.05 & 18.6 & 312 & 460 & 3772 & 3312 & 662 \\
\hline $25 \mathrm{C} 9$ & 25.0 & 6.05 & 18.6 & 314 & 462 & 3582 & 3120 & 624 \\
\hline $25 \mathrm{~A} 10$ & 25.8 & 6.07 & 18.6 & 316 & 460 & 3665 & 3205 & 641 \\
\hline $25 \mathrm{~B} 10$ & 25.8 & 6.07 & 18.6 & 317 & 462 & 3588 & 3126 & 625 \\
\hline $25 \mathrm{C} 10$ & 25.8 & 6.07 & 18.6 & 313 & 451 & 3467 & 3016 & 603 \\
\hline $25 \mathrm{~A} 11$ & 25.4 & 6.09 & 18.6 & 316 & 465 & 3317 & 2852 & 570 \\
\hline $25 \mathrm{~B} 11$ & 25.4 & 6.09 & 18.6 & 313 & 457 & 3533 & 3076 & 615 \\
\hline $25 \mathrm{C} 11$ & 25.4 & 6.09 & 18.6 & 314 & 458 & 3643 & 3185 & 637 \\
\hline 26A9 & 25.8 & 5.90 & 18.9 & 313 & 456 & 3448 & 2992 & 599 \\
\hline $26 \mathrm{~B} 9$ & 25.8 & 5.90 & 18.9 & 315 & 454 & 3503 & 3049 & 611 \\
\hline 26C9 & 25.8 & 5.90 & 18.9 & 314 & 460 & 3254 & 2794 & 560 \\
\hline $26 \mathrm{~A} 10$ & 26.2 & 5.93 & 18.6 & 312 & 455 & 3361 & 2906 & 582 \\
\hline $26 \mathrm{~B} 10$ & 26.2 & 5.93 & 18.6 & 315 & 465 & 3367 & 2902 & 581 \\
\hline $26 \mathrm{C} 10$ & 26.2 & 5.93 & 18.6 & 312 & 451 & 3399 & 2948 & 591 \\
\hline $26 \mathrm{~A} 11$ & 26.2 & 5.95 & 20.1 & 313 & 453 & 3417 & 2964 & 594 \\
\hline $26 \mathrm{~B} 11$ & 26.2 & 5.95 & 20.1 & 314 & 459 & 3595 & 3136 & 628 \\
\hline $26 \mathrm{C} 11$ & 26.2 & 5.95 & 20.1 & 315 & 452 & 3463 & 3011 & 603 \\
\hline
\end{tabular}


TABLE V

SET DATA CONT.

\begin{tabular}{|c|c|c|c|c|c|c|c|c|}
\hline ID & $\begin{array}{l}\text { Cook Size } \\
\text { Actual (L) } \\
\end{array}$ & Set pH & $\begin{array}{c}\text { Set } \\
\text { Balling } \\
(\%) \\
\end{array}$ & $\begin{array}{c}\text { Nalgene wt } \\
(\mathrm{g}) \\
\end{array}$ & $\begin{array}{c}\text { Total wt } \\
\text { w/ yeast } \\
\text { (g) } \\
\end{array}$ & $\begin{array}{c}\text { Total set } \\
\text { wt (g) } \\
\end{array}$ & $\begin{array}{c}\text { Mash wt } \\
(\mathrm{g}) \\
\end{array}$ & $\begin{array}{c}\text { g dry corn } \\
\text { mashed }\end{array}$ \\
\hline 27A9 & 25.6 & 5.99 & 18.9 & 314 & 464 & 3634 & 3170 & 634 \\
\hline 27B9 & 25.6 & 5.99 & 18.9 & 317 & 463 & 3616 & 3153 & 631 \\
\hline 27C9 & 25.6 & 5.99 & 18.9 & 312 & 455 & 3780 & 3325 & 665 \\
\hline 27A 10 & 25.8 & 6.08 & 18.9 & 313 & 454 & 3499 & 3045 & 609 \\
\hline 27B10 & 25.8 & 6.08 & 18.9 & 314 & 455 & 3485 & 3030 & 606 \\
\hline $27 \mathrm{C} 10$ & 25.8 & 6.08 & 18.9 & 314 & 453 & 3616 & 3163 & 633 \\
\hline 27A11 & 25.6 & 6.09 & 18.9 & 316 & 454 & 3429 & 2975 & 595 \\
\hline 27B11 & 25.6 & 6.09 & 18.9 & 315 & 449 & 3458 & 3009 & 602 \\
\hline $27 \mathrm{C} 11$ & 25.6 & 6.09 & 18.9 & 316 & 464 & 3383 & 2919 & 584 \\
\hline 28A9 & 26.5 & 6.03 & 18.0 & 313 & 458 & 3456 & 2998 & 598 \\
\hline 28B9 & 26.5 & 6.03 & 18.0 & 313 & 461 & 3553 & 3092 & 617 \\
\hline 28C9 & 26.5 & 6.03 & 18.0 & 312 & 454 & 3694 & 3240 & 646 \\
\hline $28 \mathrm{~A} 10$ & 26.1 & 6.07 & 18.6 & 316 & 450 & 3521 & 3071 & 612 \\
\hline 28B10 & 26.1 & 6.07 & 18.6 & 314 & 462 & 3541 & 3079 & 614 \\
\hline $28 \mathrm{C} 10$ & 26.1 & 6.07 & 18.6 & 312 & 453 & 3352 & 2899 & 578 \\
\hline 28A11 & 25.6 & 6.11 & 18.9 & 313 & 445 & 3516 & 3071 & 612 \\
\hline 28B11 & 25.6 & 6.11 & 18.9 & 313 & 466 & 3640 & 3174 & 633 \\
\hline $28 \mathrm{C} 11$ & 25.6 & 6.11 & 18.9 & 314 & 463 & 3704 & 3241 & 646 \\
\hline
\end{tabular}




\section{TABLE VI}

\section{DROP DATA}

\begin{tabular}{|c|c|c|c|c|c|c|c|c|c|}
\hline ID & Drop date & $\begin{array}{c}\text { Drop wt } \\
\text { (g) }\end{array}$ & $\begin{array}{c}\text { wt loss } \\
(\mathrm{g})\end{array}$ & $\begin{array}{c}\text { Calculated CO2 g / } \\
100 \text { g dry corn }\end{array}$ & $\begin{array}{c}\text { Drop } \\
\text { pH }\end{array}$ & $\begin{array}{c}\text { Distill } 1 \\
\text { ABV (\%) } \\
\end{array}$ & $\begin{array}{c}\text { Distill } 2 \\
\text { ABV } \\
(\%) \\
\end{array}$ & $\begin{array}{c}\operatorname{Avg} \mathbf{A B V} \\
(\%)\end{array}$ & $\begin{array}{c}\text { Drop } \\
\text { Balling } \\
(\%) \\
\end{array}$ \\
\hline $1 \mathrm{~A} 9$ & $8 / 22 / 2006$ & 3485 & 242 & 35.79 & 4.50 & 9.225 & 9.547 & 9.39 & 1.2 \\
\hline 1B9 & $8 / 22 / 2006$ & 3476 & 242 & 35.94 & 4.54 & 9.528 & 9.513 & 9.52 & 0.9 \\
\hline $1 \mathrm{C} 9$ & $8 / 22 / 2006$ & 3239 & 224 & 36.00 & 4.54 & 9.404 & 9.468 & 9.44 & 0.9 \\
\hline $1 \mathrm{~A} 10$ & $8 / 22 / 2006$ & 3309 & 234 & 36.70 & 4.41 & 9.712 & 9.735 & 9.72 & 0.9 \\
\hline $1 \mathrm{~B} 10$ & $8 / 22 / 206$ & 3378 & 238 & 36.53 & 4.42 & 9.375 & 9.737 & 9.56 & 0.9 \\
\hline $1 \mathrm{C} 10$ & $8 / 22 / 2006$ & 3499 & 247 & 36.40 & 4.35 & 9.492 & 9.600 & 9.55 & 0.9 \\
\hline $2 \mathrm{~A} 9$ & $8 / 23 / 2006$ & 3331 & 227 & 36.12 & 4.44 & 9.568 & 9.555 & 9.56 & 0.9 \\
\hline $2 \mathrm{~B} 9$ & $8 / 23 / 2006$ & 3376 & 231 & 36.17 & 4.45 & 9.570 & 9.561 & 9.57 & 0.9 \\
\hline $2 \mathrm{C} 9$ & $8 / 23 / 2006$ & 3402 & 234 & 36.30 & 4.50 & 9.557 & 9.506 & 9.53 & 0.9 \\
\hline $2 \mathrm{~A} 10$ & $8 / 23 / 2006$ & 3342 & 233 & 36.85 & 4.50 & 9.715 & 9.505 & 9.61 & 0.9 \\
\hline $2 \mathrm{~B} 10$ & $8 / 23 / 2006$ & 3568 & 250 & 36.71 & 4.54 & 9.731 & 9.746 & 9.74 & 0.9 \\
\hline $2 \mathrm{C} 10$ & $8 / 23 / 2006$ & 3411 & 238 & 36.76 & 4.52 & 9.698 & 9.719 & 9.71 & 0.9 \\
\hline $3 \mathrm{~A} 9$ & $8 / 29 / 2006$ & 3324 & 221 & 35.13 & 4.03 & 9.357 & 9.326 & 9.34 & 0.9 \\
\hline $3 \mathrm{~B} 9$ & $8 / 29 / 2006$ & 3332 & 220 & 35.03 & 4.05 & 9.280 & 9.299 & 9.29 & 0.9 \\
\hline 3C9 & $8 / 29 / 2006$ & 3275 & 218 & 35.23 & 4.00 & 9.249 & 9.356 & 9.30 & 0.9 \\
\hline $3 \mathrm{~A} 10$ & $8 / 29 / 2006$ & 3195 & 216 & 35.99 & 4.07 & 9.452 & 9.513 & 9.48 & 0.9 \\
\hline $3 \mathrm{~B} 10$ & $8 / 29 / 2006$ & 3416 & 231 & 35.65 & 3.99 & 9.481 & 9.467 & 9.47 & 0.9 \\
\hline $3 \mathrm{C} 10$ & $8 / 29 / 2006$ & 3414 & 232 & 35.85 & 4.10 & 9.354 & 9.468 & 9.41 & 0.9 \\
\hline $4 \mathrm{~A} 9$ & $8 / 30 / 2006$ & 3355 & 228 & 35.83 & 4.43 & 9.440 & 9.442 & 9.44 & 0.9 \\
\hline $4 \mathrm{~B} 9$ & $8 / 30 / 2006$ & 3387 & 230 & 35.80 & 4.46 & 9.492 & 9.373 & 9.43 & 0.9 \\
\hline $4 \mathrm{C} 9$ & $8 / 30 / 2006$ & 3417 & 232 & 35.70 & 4.43 & 9.500 & 9.500 & 9.50 & 0.9 \\
\hline $4 \mathrm{~A} 10$ & $8 / 30 / 2006$ & 3260 & 227 & 36.86 & 4.62 & 9.749 & 9.754 & 9.75 & 0.9 \\
\hline 4B10 & $8 / 30 / 2006$ & 3363 & 235 & 36.87 & 4.52 & 9.662 & 9.732 & 9.70 & 0.9 \\
\hline $5 \mathrm{~A} 9$ & $9 / 13 / 2006$ & 3506 & 252 & 37.42 & 4.52 & 10.330 & 10.654 & 10.49 & 0.3 \\
\hline $5 \mathrm{~B} 9$ & $9 / 13 / 2006$ & 3421 & 246 & 37.48 & 4.54 & 10.334 & 10.302 & 10.32 & 0.3 \\
\hline $5 \mathrm{C} 9$ & $9 / 13 / 2006$ & 3429 & 245 & 37.25 & 4.55 & 10.319 & 10.358 & 10.34 & 0.3 \\
\hline $5 \mathrm{~A} 10$ & $9 / 13 / 2006$ & 3344 & 241 & 37.81 & 4.54 & 10.474 & 10.418 & 10.45 & 0.3 \\
\hline $5 \mathrm{~B} 10$ & $9 / 13 / 2006$ & 3359 & 242 & 37.76 & 4.56 & 10.446 & 10.405 & 10.43 & 0.3 \\
\hline $5 \mathrm{C} 10$ & $9 / 13 / 2006$ & 3472 & 250 & 37.68 & 4.63 & 10.467 & 10.477 & 10.47 & 0.3 \\
\hline $6 \mathrm{~A} 9$ & $9 / 15 / 2006$ & 3387 & 208 & 32.44 & 3.85 & 8.698 & 8.719 & 8.71 & 1.2 \\
\hline $6 \mathrm{~B} 9$ & $9 / 15 / 2006$ & 3452 & 212 & 32.33 & 3.86 & 8.727 & 8.738 & 8.73 & 1.5 \\
\hline $6 \mathrm{C} 9$ & $9 / 15 / 2006$ & 3246 & 197 & 32.25 & 3.87 & 8.663 & 8.707 & 8.69 & 1.2 \\
\hline $6 \mathrm{~A} 10$ & $9 / 15 / 2006$ & 3392 & 205 & 31.91 & 3.88 & 8.473 & 8.592 & 8.53 & 1.2 \\
\hline $6 \mathrm{~B} 10$ & $9 / 15 / 2006$ & 3406 & 206 & 31.98 & 3.91 & 8.514 & 8.605 & 8.56 & 1.2 \\
\hline $6 \mathrm{C} 10$ & $9 / 15 / 2006$ & 3480 & 212 & 32.02 & 3.87 & 8.666 & 8.680 & 8.67 & 1.2 \\
\hline $6 \mathrm{~A} 11$ & $9 / 15 / 2006$ & 3386 & 214 & 33.33 & 3.96 & 8.967 & 8.888 & 8.93 & 0.9 \\
\hline $6 \mathrm{~B} 11$ & $9 / 15 / 2006$ & 3226 & 203 & 33.37 & 3.93 & 9.006 & 8.809 & 8.91 & 1.2 \\
\hline $6 \mathrm{C} 11$ & $9 / 15 / 2006$ & 3316 & 231 & 36.60 & 3.93 & 8.984 & 8.965 & 8.97 & 0.9 \\
\hline
\end{tabular}




\section{TABLE VI}

DROP DATA CONT.

\begin{tabular}{|c|c|c|c|c|c|c|c|c|c|}
\hline ID & Drop date & $\begin{array}{c}\text { Drop wt } \\
(\mathrm{g})\end{array}$ & wt loss (g) & $\begin{array}{c}\text { Calculated } \mathrm{CO} 2 \mathrm{~g} / \\
100 \mathrm{~g} \text { dry corn } \\
\end{array}$ & $\begin{array}{c}\text { Drop } \\
\text { pH }\end{array}$ & $\begin{array}{c}\text { Distill 1 } \\
\text { ABV } \\
(\%) \\
\end{array}$ & $\begin{array}{r}\text { Distill } 2 \\
\text { ABV (\%) } \\
\end{array}$ & $\begin{array}{c}\text { Avg } \\
\text { ABV } \\
(\%) \\
\end{array}$ & $\begin{array}{c}\text { Drop } \\
\text { Balling } \\
(\%) \\
\end{array}$ \\
\hline 7A9 & $9 / 19 / 2006$ & 3320 & 222 & 34.64 & 4.39 & 9.422 & 9.440 & 9.43 & 0.6 \\
\hline $7 \mathrm{~B} 9$ & $9 / 19 / 2006$ & 3276 & 220 & 34.77 & 4.39 & 9.428 & 9.451 & 9.44 & 0.9 \\
\hline 7C9 & $9 / 19 / 2006$ & 3376 & 228 & 34.84 & 4.39 & 9.457 & 9.453 & 9.46 & 0.9 \\
\hline 7A10 & $9 / 19 / 2006$ & 3368 & 213 & 32.73 & 3.99 & 8.877 & 8.897 & 8.89 & 0.9 \\
\hline $7 \mathrm{~B} 10$ & $9 / 19 / 2006$ & 3361 & 213 & 32.86 & 3.99 & 8.765 & 8.870 & 8.82 & 1.2 \\
\hline $7 \mathrm{C} 10$ & $9 / 19 / 2006$ & 3519 & 224 & 32.82 & 4.00 & 8.893 & 8.841 & 8.87 & 1.2 \\
\hline 7A11 & $9 / 19 / 2006$ & 3414 & 225 & 34.01 & 4.30 & 9.216 & 9.168 & 9.19 & 1.2 \\
\hline 7B11 & $9 / 19 / 2006$ & 3331 & 220 & 34.24 & 4.32 & 9.177 & 9.189 & 9.18 & 1.2 \\
\hline $7 \mathrm{C} 11$ & $9 / 19 / 2006$ & 3476 & 229 & 33.89 & 4.31 & 9.248 & 9.230 & 9.24 & 0.9 \\
\hline $8 \mathrm{~A} 9$ & $9 / 20 / 2006$ & 3425 & 215 & 32.47 & 4.26 & 8.822 & 8.809 & 8.82 & 0.6 \\
\hline $8 B 9$ & $9 / 20 / 2006$ & 3170 & 197 & 32.56 & 4.28 & 8.748 & 8.791 & 8.77 & 0.9 \\
\hline $8 \mathrm{C} 9$ & $9 / 20 / 2006$ & 3400 & 215 & 32.72 & 4.28 & 8.809 & 8.788 & 8.80 & 0.9 \\
\hline 8A10 & 9/20/2006 & 3268 & 209 & 33.29 & 4.11 & 8.866 & 8.874 & 8.87 & 0.9 \\
\hline $8 \mathrm{~B} 10$ & $9 / 20 / 2006$ & 3392 & 216 & 32.95 & 4.09 & 8.891 & 8.875 & 8.88 & 1.2 \\
\hline $8 \mathrm{C} 10$ & $9 / 20 / 2006$ & 3339 & 214 & 33.18 & 4.08 & 8.874 & 8.900 & 8.89 & 0.9 \\
\hline 8A11 & 9/20/2006 & 3345 & 212 & 32.90 & 4.43 & 8.910 & 8.938 & 8.92 & 0.6 \\
\hline $8 \mathrm{~B} 11$ & $9 / 20 / 2006$ & 3178 & 201 & 33.11 & 4.43 & 8.921 & 8.920 & 8.92 & 0.9 \\
\hline $8 \mathrm{C} 11$ & $9 / 20 / 2006$ & 3215 & 204 & 33.12 & 4.44 & 8.955 & 8.933 & 8.94 & 0.6 \\
\hline 9A9 & $9 / 26 / 2006$ & 3167 & 197 & 32.45 & 4.10 & 6.940 & 8.730 & 7.84 & 0.5 \\
\hline $9 \mathrm{~B} 9$ & $9 / 26 / 2006$ & 3406 & 214 & 32.44 & 4.15 & 8.880 & 8.860 & 8.87 & 0.8 \\
\hline 9C9 & $9 / 26 / 2006$ & 3413 & 213 & 32.24 & 4.14 & 8.920 & 8.950 & 8.94 & 1.2 \\
\hline 9A10 & $9 / 26 / 2006$ & 3237 & 202 & 32.41 & 4.04 & 8.960 & 8.950 & 8.96 & 1.2 \\
\hline 9B10 & $9 / 26 / 2006$ & 3308 & 207 & 32.48 & 4.04 & 8.760 & 8.970 & 8.87 & 1.2 \\
\hline $9 \mathrm{C} 10$ & $9 / 26 / 2006$ & 3274 & 205 & 32.54 & 4.05 & 8.950 & 8.920 & 8.94 & 0.8 \\
\hline 9A11 & $9 / 26 / 2006$ & 3481 & 216 & 32.02 & 4.10 & 8.770 & 8.790 & 8.78 & 0.0 \\
\hline $9 \mathrm{~B} 11$ & $9 / 26 / 2006$ & 3525 & 222 & 32.36 & 4.10 & 8.860 & 9.990 & 9.43 & 0.4 \\
\hline $9 \mathrm{C} 11$ & $9 / 26 / 2006$ & 3626 & 227 & 32.07 & 4.05 & 8.900 & 10.280 & 9.59 & 0.4 \\
\hline $10 \mathrm{~A} 9$ & $9 / 27 / 2006$ & 3451 & 223 & 33.39 & 4.22 & 9.200 & 9.102 & 9.15 & 0.8 \\
\hline 10B9 & 9/27/2006 & 3284 & 211 & 33.58 & 4.30 & 9.057 & 9.090 & 9.07 & 0.6 \\
\hline $10 \mathrm{C} 9$ & $9 / 27 / 2006$ & 3470 & 226 & 33.63 & 4.33 & 9.002 & 9.118 & 9.06 & 0.4 \\
\hline $10 \mathrm{~A} 10$ & $9 / 27 / 2006$ & 3258 & 208 & 33.35 & 4.31 & 9.061 & 9.088 & 9.07 & 0.2 \\
\hline 10B10 & $9 / 27 / 2006$ & 3471 & 225 & 33.50 & 4.32 & 9.117 & 9.090 & 9.10 & 0.0 \\
\hline $10 \mathrm{C} 10$ & $9 / 27 / 2006$ & 3388 & 218 & 33.38 & 4.33 & 9.033 & 9.057 & 9.05 & 1.0 \\
\hline $10 \mathrm{~A} 11$ & $9 / 27 / 2006$ & 3509 & 228 & 33.58 & 4.31 & 9.084 & 9.133 & 9.11 & 0.4 \\
\hline 10B11 & $9 / 27 / 2006$ & 3491 & 227 & 33.64 & 4.33 & 8.978 & 9.088 & 9.03 & 0.6 \\
\hline $10 \mathrm{C} 11$ & $9 / 27 / 2006$ & 3375 & 218 & 33.50 & 4.35 & 9.140 & 9.183 & 9.16 & 0.4 \\
\hline $11 \mathrm{~A} 9$ & $10 / 10 / 2006$ & 3392 & 221 & 34.08 & 4.40 & 9.178 & 9.140 & 9.16 & 1.8 \\
\hline 11B9 & $10 / 10 / 2006$ & 3439 & 226 & 34.30 & 4.37 & 8.991 & 9.145 & 9.07 & 1.8 \\
\hline $11 \mathrm{C} 9$ & $10 / 10 / 2006$ & 3285 & 221 & 35.25 & 4.31 & 9.182 & 9.164 & 9.17 & 1.5 \\
\hline $11 \mathrm{~A} 10$ & $10 / 10 / 2006$ & 3282 & 237 & 37.70 & 4.47 & 10.080 & 10.097 & 10.09 & 1.5 \\
\hline 11B10 & $10 / 10 / 2006$ & 3427 & 247 & 37.45 & 4.49 & 10.052 & 10.077 & 10.06 & 1.5 \\
\hline $11 \mathrm{C} 10$ & $10 / 10 / 2006$ & 3292 & 237 & 37.56 & 4.47 & 10.118 & 10.068 & 10.09 & 1.5 \\
\hline
\end{tabular}




\section{TABLE VI}

DROP DATA CONT.

\begin{tabular}{|c|c|c|c|c|c|c|c|c|c|}
\hline ID & Drop date & $\begin{array}{c}\text { Drop wt } \\
(\mathrm{g})\end{array}$ & $\begin{array}{c}\text { wt loss } \\
(\mathrm{g})\end{array}$ & $\begin{array}{c}\text { Calculated } \mathrm{CO} 2 \mathrm{~g} / \\
100 \text { g dry corn }\end{array}$ & $\begin{array}{c}\text { Drop } \\
\text { pH }\end{array}$ & $\begin{array}{c}\text { Distill } 1 \\
\text { ABV } \\
(\%) \\
\end{array}$ & $\begin{array}{c}\text { Distill } 2 \\
\text { ABV (\%) } \\
\end{array}$ & $\begin{array}{c}\text { Avg } \\
\text { ABV } \\
(\%) \\
\end{array}$ & $\begin{array}{c}\text { Drop } \\
\text { Balling } \\
(\%) \\
\end{array}$ \\
\hline $12 \mathrm{~A} 9$ & $10 / 11 / 2006$ & 3355 & 231 & 36.20 & 4.42 & 9.554 & 9.600 & 9.58 & 1.8 \\
\hline 12B9 & $10 / 11 / 2006$ & 3317 & 229 & 36.33 & 4.41 & 9.651 & 9.636 & 9.64 & 1.5 \\
\hline $12 \mathrm{C} 9$ & $10 / 11 / 2006$ & 3350 & 230 & 36.15 & 4.49 & 9.635 & 9.595 & 9.62 & 1.5 \\
\hline $12 \mathrm{~A} 10$ & $10 / 11 / 2006$ & 3468 & 246 & 37.05 & 4.49 & 9.760 & 9.776 & 9.77 & 1.5 \\
\hline $12 \mathrm{~B} 10$ & $10 / 11 / 2006$ & 3071 & 213 & 36.82 & 4.59 & 9.757 & 9.805 & 9.78 & 1.2 \\
\hline $12 \mathrm{C} 10$ & $10 / 11 / 2006$ & 3419 & 240 & 36.73 & 4.55 & 9.827 & 9.807 & 9.82 & 1.2 \\
\hline 13A9 & $10 / 17 / 2006$ & 3400 & 200 & 31.09 & 4.02 & 8.187 & 8.214 & 8.20 & 1.5 \\
\hline 13B9 & $10 / 17 / 2006$ & 3299 & 198 & 31.75 & 4.03 & 8.350 & 8.378 & 8.36 & 0.9 \\
\hline $13 \mathrm{C} 9$ & $10 / 17 / 2006$ & 3549 & 214 & 31.58 & 4.05 & 8.385 & 8.289 & 8.34 & 1.5 \\
\hline $13 \mathrm{~A} 10$ & $10 / 17 / 2006$ & 3407 & 209 & 32.37 & 4.09 & 8.543 & 8.536 & 8.54 & 0.9 \\
\hline 13B10 & $10 / 17 / 2006$ & 3088 & 189 & 32.78 & 3.95 & 8.323 & 8.337 & 8.33 & 0.9 \\
\hline $13 \mathrm{C} 10$ & $10 / 17 / 2006$ & 3139 & 186 & 31.70 & 3.91 & 8.633 & 8.639 & 8.64 & 0.3 \\
\hline $13 \mathrm{~A} 11$ & $10 / 17 / 2006$ & 3492 & 223 & 33.39 & 4.27 & 8.854 & 8.931 & 8.89 & 0.9 \\
\hline 13B11 & $10 / 17 / 2006$ & 3539 & 225 & 33.26 & 4.25 & 8.854 & 8.884 & 8.87 & 0.9 \\
\hline $13 \mathrm{C} 11$ & $10 / 17 / 2006$ & 3331 & 211 & 33.41 & 4.24 & 8.931 & 8.895 & 8.91 & 0.9 \\
\hline $14 \mathrm{~A} 9$ & $10 / 18 / 2006$ & 3234 & 217 & 35.99 & 4.33 & 9.177 & 8.868 & 9.02 & 0.6 \\
\hline 14B9 & $10 / 18 / 2006$ & 3461 & 232 & 35.43 & 4.39 & 9.238 & 9.328 & 9.28 & 0.6 \\
\hline 14C9 & $10 / 18 / 2006$ & 3376 & 224 & 35.35 & 4.36 & 9.304 & 9.295 & 9.30 & 0.6 \\
\hline $14 \mathrm{~A} 10$ & $10 / 18 / 2006$ & 3232 & 219 & 36.23 & 4.44 & 9.471 & 9.471 & 9.47 & 0.3 \\
\hline 14B10 & $10 / 18 / 2006$ & 3378 & 230 & 36.24 & 4.43 & 9.540 & 9.531 & 9.54 & 0.6 \\
\hline $14 \mathrm{C} 10$ & $10 / 18 / 2006$ & 3311 & 224 & 36.11 & 4.39 & 9.501 & 9.531 & 9.52 & 0.6 \\
\hline $15 \mathrm{~A} 9$ & $10 / 24 / 2006$ & 3297 & 213 & 34.20 & 4.45 & 9.070 & 9.090 & 9.08 & 0.3 \\
\hline 15B9 & $10 / 24 / 2006$ & 3420 & 223 & 34.34 & 4.46 & 9.105 & 9.091 & 9.10 & 0.3 \\
\hline $15 \mathrm{C} 9$ & $10 / 24 / 2006$ & 3566 & 234 & 34.36 & 4.44 & 9.193 & 9.146 & 9.17 & 0.3 \\
\hline $15 \mathrm{~A} 10$ & $10 / 24 / 2006$ & 3196 & 207 & 34.42 & 4.21 & 9.120 & 9.107 & 9.11 & 1.5 \\
\hline $15 \mathrm{~B} 10$ & $10 / 24 / 2006$ & 3404 & 220 & 34.08 & 4.24 & 9.047 & 9.078 & 9.06 & 1.8 \\
\hline $15 \mathrm{C} 10$ & $10 / 24 / 2006$ & 3435 & 227 & 34.74 & 4.23 & 9.179 & 9.152 & 9.17 & 1.5 \\
\hline $16 \mathrm{~A} 9$ & $10 / 25 / 2006$ & 3334 & 212 & 33.99 & 4.23 & 8.818 & 8.904 & 8.86 & 1.2 \\
\hline 16B9 & $10 / 25 / 2006$ & 3155 & 201 & 34.48 & 4.30 & 8.870 & 8.871 & 8.87 & 1.2 \\
\hline $16 \mathrm{C} 9$ & $10 / 25 / 2006$ & 3288 & 209 & 33.98 & 4.18 & 8.912 & 8.878 & 8.90 & 1.2 \\
\hline $16 \mathrm{~A} 10$ & $10 / 25 / 2006$ & 3337 & 218 & 34.82 & 4.23 & 9.151 & 9.157 & 9.15 & 1.5 \\
\hline 16B10 & $10 / 25 / 2006$ & 3373 & 221 & 34.88 & 4.24 & 9.193 & 9.183 & 9.19 & 1.2 \\
\hline $16 \mathrm{C} 10$ & $10 / 25 / 2006$ & 3407 & 225 & 35.03 & 4.28 & 9.092 & 9.225 & 9.16 & 1.2 \\
\hline $16 \mathrm{~A} 11$ & $10 / 25 / 2006$ & 3365 & 212 & 33.63 & 3.97 & 8.774 & 8.603 & 8.69 & 1.2 \\
\hline 16B11 & $10 / 25 / 2006$ & 3594 & 227 & 33.46 & 3.95 & 8.746 & 8.767 & 8.76 & 1.2 \\
\hline $16 \mathrm{C} 11$ & $10 / 25 / 2006$ & 3381 & 212 & 33.40 & 3.96 & 8.747 & 8.739 & 8.74 & 1.2 \\
\hline 17A9 & $10 / 31 / 2006$ & 3330 & 221 & 34.17 & 4.46 & 9.365 & 9.361 & 9.36 & 0.9 \\
\hline 17B9 & $10 / 31 / 2006$ & 3287 & 219 & 34.49 & 4.43 & 9.329 & 9.332 & 9.33 & 0.9 \\
\hline $17 \mathrm{C} 9$ & $10 / 31 / 2006$ & 3317 & 220 & 34.21 & 4.45 & 9.682 & 9.471 & 9.58 & 0.9 \\
\hline $17 \mathrm{~A} 10$ & $10 / 31 / 2006$ & 3385 & 226 & 34.29 & 4.41 & 9.435 & 9.433 & 9.43 & 0.6 \\
\hline 17B10 & $10 / 31 / 2006$ & 3496 & 234 & 34.28 & 4.44 & 9.435 & 9.437 & 9.44 & 0.9 \\
\hline $17 \mathrm{C} 10$ & $10 / 31 / 2006$ & 3488 & 234 & 34.40 & 4.41 & 9.415 & 9.412 & 9.41 & 0.9 \\
\hline
\end{tabular}




\section{TABLE VI}

DROP DATA CONT.

\begin{tabular}{|c|c|c|c|c|c|c|c|c|c|}
\hline ID & Drop date & $\begin{array}{c}\text { Drop wt } \\
\text { (g) }\end{array}$ & $\begin{array}{c}\text { wt loss } \\
(\mathrm{g})\end{array}$ & $\begin{array}{c}\text { Calculated } \mathrm{CO} 2 \mathrm{~g} / \\
100 \text { g dry corn }\end{array}$ & $\begin{array}{c}\text { Drop } \\
\text { pH }\end{array}$ & $\begin{array}{r}\text { Distill } 1 \\
\text { ABV (\%) } \\
\end{array}$ & $\begin{array}{c}\text { Distill } 2 \\
\text { ABV } \\
(\%)\end{array}$ & $\begin{array}{c}\text { Avg } \\
\text { ABV } \\
(\%) \\
\end{array}$ & $\begin{array}{c}\text { Drop } \\
\text { Balling } \\
(\%)\end{array}$ \\
\hline 18A9 & $11 / 1 / 2006$ & 3476 & 226 & 34.52 & 4.12 & 9.082 & 9.094 & 9.09 & 0.6 \\
\hline 18B9 & $11 / 1 / 2006$ & 3354 & 216 & 34.49 & 4.15 & 9.024 & 9.062 & 9.04 & 1.5 \\
\hline $18 \mathrm{C} 9$ & $11 / 1 / 2006$ & 3238 & 208 & 34.57 & 4.12 & 9.053 & 9.002 & 9.03 & 1.2 \\
\hline $18 \mathrm{~A} 10$ & 11/1/2006 & 3166 & 203 & 34.54 & 4.07 & 9.020 & 9.024 & 9.02 & 1.5 \\
\hline $18 \mathrm{~B} 10$ & $11 / 1 / 2006$ & 3309 & 213 & 34.46 & 4.07 & 9.064 & 9.051 & 9.06 & 1.2 \\
\hline $18 \mathrm{C} 10$ & $11 / 1 / 2006$ & 3374 & 218 & 34.60 & 4.04 & 9.062 & 9.025 & 9.04 & 1.2 \\
\hline $18 \mathrm{~A} 11$ & $11 / 1 / 2006$ & 3127 & 196 & 34.03 & 4.07 & 8.864 & 8.882 & 8.87 & 1.2 \\
\hline 18B11 & $11 / 1 / 2006$ & 3155 & 199 & 34.16 & 4.07 & 8.871 & 8.907 & 8.89 & 1.5 \\
\hline $18 \mathrm{C} 11$ & $11 / 1 / 2006$ & 3452 & 221 & 34.08 & 4.07 & 8.873 & 8.867 & 8.87 & 1.8 \\
\hline 19A9 & $11 / 8 / 2006$ & 3157 & 213 & 35.84 & 4.40 & 9.411 & 9.517 & 9.46 & 0.6 \\
\hline 19B9 & $11 / 8 / 2006$ & 3428 & 235 & 35.81 & 4.45 & 9.600 & 9.583 & 9.59 & 0.6 \\
\hline $19 \mathrm{C} 9$ & $11 / 8 / 2006$ & 3421 & 235 & 35.89 & 4.46 & 9.615 & 9.559 & 9.59 & 0.6 \\
\hline 19A10 & $11 / 8 / 2006$ & 3232 & 224 & 36.49 & 4.49 & 9.742 & 9.747 & 9.74 & 0.6 \\
\hline 19B10 & $11 / 8 / 2006$ & 3365 & 234 & 36.41 & 4.49 & 9.847 & 9.798 & 9.82 & 0.6 \\
\hline $19 \mathrm{C} 10$ & $11 / 8 / 2006$ & 3471 & 243 & 36.49 & 4.50 & 9.685 & 9.632 & 9.66 & 0.6 \\
\hline $20 \mathrm{~A} 9$ & $11 / 15 / 2006$ & 3338 & 213 & 34.11 & 3.87 & 8.914 & 8.961 & 8.94 & 2.4 \\
\hline 20B9 & $11 / 15 / 2006$ & 3169 & 200 & 34.02 & 3.96 & 8.916 & 8.925 & 8.92 & 2.1 \\
\hline $20 \mathrm{C} 9$ & $11 / 15 / 2006$ & 3355 & 213 & 34.00 & 3.98 & 8.956 & 8.933 & 8.94 & 2.1 \\
\hline $20 \mathrm{~A} 10$ & $11 / 15 / 2006$ & 3386 & 220 & 34.73 & 4.19 & 8.996 & 9.026 & 9.01 & 1.8 \\
\hline $20 \mathrm{~B} 10$ & $11 / 15 / 2006$ & 3236 & 208 & 34.57 & 4.21 & 9.047 & 9.025 & 9.04 & 1.8 \\
\hline $20 \mathrm{C} 10$ & $11 / 15 / 2006$ & 3438 & 222 & 34.49 & 4.18 & 9.050 & 9.055 & 9.05 & 1.8 \\
\hline $20 \mathrm{~A} 11$ & $11 / 15 / 2006$ & 3373 & 215 & 34.00 & 4.04 & 8.941 & 8.933 & 8.94 & 1.8 \\
\hline 20B11 & $11 / 15 / 2006$ & 3221 & 204 & 34.12 & 4.05 & 8.832 & 8.894 & 8.86 & 1.5 \\
\hline $20 \mathrm{C} 11$ & $11 / 15 / 2006$ & 3337 & 211 & 33.90 & 4.04 & 8.792 & 8.803 & 8.80 & 1.5 \\
\hline $21 \mathrm{~A} 9$ & $11 / 21 / 2006$ & 3371 & 220 & 35.03 & 3.85 & 9.200 & 9.196 & 9.20 & 1.8 \\
\hline $21 \mathrm{~B} 9$ & $11 / 21 / 2006$ & 3389 & 222 & 35.21 & 3.91 & 9.202 & 9.241 & 9.22 & 1.8 \\
\hline $21 \mathrm{C} 9$ & $11 / 21 / 2006$ & 3141 & 205 & 35.47 & 3.92 & 9.213 & 9.196 & 9.20 & 1.8 \\
\hline $21 \mathrm{~A} 10$ & $11 / 21 / 2006$ & 3498 & 231 & 35.29 & 4.13 & 9.270 & 9.300 & 9.29 & 1.2 \\
\hline 21B10 & $11 / 21 / 2006$ & 3368 & 223 & 35.53 & 4.15 & 9.336 & 9.296 & 9.32 & 1.2 \\
\hline $21 \mathrm{C} 10$ & $11 / 21 / 2006$ & 3382 & 223 & 35.43 & 4.19 & 9.134 & 9.285 & 9.21 & 1.2 \\
\hline $21 \mathrm{~A} 11$ & $11 / 21 / 2006$ & 3325 & 211 & 34.19 & 3.96 & 8.990 & 8.978 & 8.98 & 1.5 \\
\hline 21B11 & $11 / 21 / 2006$ & 3353 & 213 & 34.24 & 3.96 & 8.961 & 8.958 & 8.96 & 1.8 \\
\hline $21 \mathrm{C} 11$ & $11 / 21 / 2006$ & 3586 & 231 & 34.31 & 3.95 & 8.623 & 8.507 & 8.57 & 1.5 \\
\hline $22 \mathrm{~A} 9$ & $11 / 22 / 2006$ & 3348 & 223 & 35.67 & 4.15 & 9.397 & 9.397 & 9.40 & 0.9 \\
\hline $22 \mathrm{~B} 9$ & $11 / 22 / 2006$ & 3516 & 235 & 35.59 & 4.14 & 9.433 & 9.386 & 9.41 & 0.9 \\
\hline $22 \mathrm{C} 9$ & $11 / 22 / 2006$ & 3535 & 237 & 35.65 & 4.14 & 9.457 & 9.425 & 9.44 & 0.9 \\
\hline $22 \mathrm{~A} 10$ & $11 / 22 / 2006$ & 3209 & 210 & 35.35 & 4.22 & 9.203 & 9.162 & 9.18 & 1.2 \\
\hline 22B10 & $11 / 22 / 2006$ & 3448 & 227 & 35.18 & 4.19 & 9.149 & 9.185 & 9.17 & 0.9 \\
\hline $22 \mathrm{C} 10$ & $11 / 22 / 2006$ & 3214 & 209 & 35.12 & 4.24 & 9.197 & 9.152 & 9.17 & 1.2 \\
\hline $22 \mathrm{~A} 11$ & $11 / 22 / 2006$ & 3329 & 219 & 35.28 & 4.15 & 9.287 & 9.298 & 9.29 & 1.5 \\
\hline 22B11 & $11 / 22 / 2006$ & 3255 & 213 & 35.26 & 4.12 & 9.275 & 9.224 & 9.25 & 1.5 \\
\hline $22 \mathrm{C} 11$ & $11 / 22 / 2006$ & 3461 & 227 & 35.03 & 4.13 & 9.320 & 9.322 & 9.32 & 1.2 \\
\hline
\end{tabular}




\section{TABLE VI}

DROP DATA CONT.

\begin{tabular}{|c|c|c|c|c|c|c|c|c|c|}
\hline ID & Drop date & $\begin{array}{c}\text { Drop wt } \\
(\mathrm{g})\end{array}$ & $\begin{array}{c}\text { wt loss } \\
(\mathrm{g})\end{array}$ & $\begin{array}{c}\text { Calculated } \mathrm{CO} 2 \mathrm{~g} / \\
100 \mathrm{~g} \text { dry corn } \\
\end{array}$ & $\begin{array}{c}\text { Drop } \\
\text { pH }\end{array}$ & $\begin{array}{c}\text { Distill 1 } \\
\text { ABV (\%) } \\
\end{array}$ & $\begin{array}{c}\text { Distill } 2 \\
\text { ABV } \\
(\%) \\
\end{array}$ & $\begin{array}{l}\text { Avg } \\
\text { ABV } \\
(\%) \\
\end{array}$ & $\begin{array}{c}\text { Drop } \\
\text { Balling } \\
(\%) \\
\end{array}$ \\
\hline $23 \mathrm{~A} 9$ & $12 / 5 / 2006$ & 3266 & 215 & 35.63 & 4.29 & 9.327 & 9.346 & 9.34 & 0.9 \\
\hline 23B9 & $12 / 5 / 2006$ & 3311 & 221 & 35.96 & 4.33 & 9.400 & 9.393 & 9.40 & 0.6 \\
\hline $23 \mathrm{C} 9$ & $12 / 5 / 2006$ & 3300 & 222 & 36.17 & 4.35 & 9.614 & 9.653 & 9.63 & 0.3 \\
\hline $23 \mathrm{~A} 10$ & $12 / 5 / 2006$ & 3263 & 224 & 37.01 & 4.30 & 9.670 & 9.626 & 9.65 & 0.6 \\
\hline 23B10 & $12 / 5 / 2006$ & 3338 & 231 & 37.12 & 4.42 & 9.747 & 9.674 & 9.71 & 0.9 \\
\hline $23 \mathrm{C} 10$ & $12 / 5 / 2006$ & 3172 & 220 & 37.49 & 4.41 & 9.636 & 9.686 & 9.66 & 0.9 \\
\hline $23 \mathrm{~A} 11$ & $12 / 5 / 2006$ & 3434 & 230 & 35.86 & 4.31 & 9.442 & 9.353 & 9.40 & 1.2 \\
\hline 23B11 & $12 / 5 / 2006$ & 3401 & 227 & 35.82 & 4.35 & 9.431 & 9.376 & 9.40 & 0.9 \\
\hline $23 \mathrm{C} 11$ & $12 / 5 / 2006$ & 3637 & 246 & 35.91 & 4.34 & 9.426 & 9.446 & 9.44 & 0.9 \\
\hline $24 \mathrm{~A} 9$ & $12 / 6 / 2006$ & 3413 & 228 & 35.70 & 4.22 & 9.334 & 9.450 & 9.39 & 0.6 \\
\hline 24B9 & $12 / 6 / 2006$ & 3309 & 221 & 35.87 & 4.33 & 9.389 & 9.430 & 9.41 & 0.6 \\
\hline $24 \mathrm{C} 9$ & $12 / 6 / 2006$ & 3456 & 232 & 35.79 & 4.35 & 9.437 & 9.440 & 9.44 & 0.6 \\
\hline $24 \mathrm{~A} 10$ & $12 / 6 / 2006$ & 3204 & 213 & 35.89 & 4.40 & 9.309 & 9.284 & 9.30 & 0.6 \\
\hline 24B10 & $12 / 6 / 2006$ & 3219 & 212 & 35.54 & 4.41 & 9.305 & 9.306 & 9.31 & 0.6 \\
\hline $24 \mathrm{C} 10$ & $12 / 6 / 2006$ & 3300 & 219 & 35.76 & 4.42 & 9.314 & 9.227 & 9.27 & 0.6 \\
\hline $24 \mathrm{~A} 11$ & $12 / 6 / 2006$ & 3514 & 235 & 35.55 & 4.14 & 9.261 & 9.296 & 9.28 & 0.9 \\
\hline 24B11 & $12 / 6 / 2006$ & 3473 & 229 & 35.19 & 4.19 & 9.266 & 9.243 & 9.25 & 0.9 \\
\hline $24 \mathrm{C} 11$ & $12 / 6 / 2006$ & 3414 & 225 & 35.25 & 4.11 & 9.249 & 9.285 & 9.27 & 1.2 \\
\hline $25 \mathrm{~A} 9$ & $12 / 12 / 2006$ & 3206 & 210 & 35.47 & 4.43 & 9.176 & 9.170 & 9.17 & 0.9 \\
\hline $25 \mathrm{~B} 9$ & $12 / 12 / 2006$ & 3537 & 235 & 35.50 & 4.41 & 9.190 & 9.228 & 9.21 & 0.9 \\
\hline $25 \mathrm{C} 9$ & $12 / 12 / 2006$ & 3360 & 222 & 35.60 & 4.45 & 9.192 & 9.203 & 9.20 & 0.9 \\
\hline $25 \mathrm{~A} 10$ & $12 / 12 / 2006$ & 3437 & 228 & 35.59 & 4.61 & 9.279 & 9.243 & 9.26 & 0.9 \\
\hline $25 \mathrm{~B} 10$ & $12 / 12 / 2006$ & 3367 & 221 & 35.37 & 4.59 & 9.185 & 9.262 & 9.22 & 0.9 \\
\hline $25 \mathrm{C} 10$ & $12 / 12 / 2006$ & 3252 & 215 & 35.66 & 4.65 & 9.255 & 9.250 & 9.25 & 0.9 \\
\hline $25 \mathrm{~A} 11$ & $12 / 12 / 2006$ & 3110 & 207 & 36.31 & 4.35 & 9.235 & 9.238 & 9.24 & 0.9 \\
\hline $25 \mathrm{~B} 11$ & $12 / 12 / 2006$ & 3300 & 233 & 37.90 & 4.31 & 9.337 & 9.340 & 9.34 & 0.9 \\
\hline $25 \mathrm{C} 11$ & $12 / 12 / 2006$ & 3413 & 230 & 36.13 & 4.33 & 9.196 & 9.117 & 9.16 & 0.9 \\
\hline 26A9 & $12 / 13 / 2006$ & 3236 & 212 & 35.37 & 4.47 & 9.232 & 9.238 & 9.24 & 0.9 \\
\hline $26 \mathrm{~B} 9$ & $12 / 13 / 2006$ & 3285 & 218 & 35.69 & 4.56 & 9.250 & 9.241 & 9.25 & 0.9 \\
\hline $26 \mathrm{C} 9$ & $12 / 13 / 2006$ & 3055 & 199 & 35.55 & 4.55 & 9.233 & 9.217 & 9.23 & 0.9 \\
\hline $26 \mathrm{~A} 10$ & $12 / 13 / 2006$ & 3151 & 210 & 36.07 & 4.69 & 9.394 & 9.382 & 9.39 & 0.9 \\
\hline $26 \mathrm{~B} 10$ & $12 / 13 / 2006$ & 3157 & 210 & 36.12 & 4.69 & 9.409 & 9.380 & 9.39 & 0.9 \\
\hline $26 \mathrm{C} 10$ & $12 / 13 / 2006$ & 3186 & 213 & 36.06 & 4.68 & 9.460 & 9.425 & 9.44 & 0.9 \\
\hline $26 \mathrm{~A} 11$ & $12 / 13 / 2006$ & 3207 & 210 & 35.36 & 4.65 & 9.224 & 9.253 & 9.24 & 0.9 \\
\hline 26B11 & $12 / 13 / 2006$ & 3373 & 222 & 35.34 & 4.66 & 9.248 & 9.267 & 9.26 & 0.9 \\
\hline $26 \mathrm{C} 11$ & $12 / 13 / 2006$ & 3249 & 214 & 35.48 & 4.65 & 9.342 & 9.256 & 9.30 & 0.9 \\
\hline
\end{tabular}


TABLE VI

DROP DATA CONT.

\begin{tabular}{|c|c|c|c|c|c|c|c|c|c|}
\hline ID & Drop date & $\begin{array}{c}\text { Drop wt } \\
(\mathrm{g}) \\
\end{array}$ & $\begin{array}{c}\text { wt loss } \\
(\mathrm{g}) \\
\end{array}$ & $\begin{array}{c}\text { Calculated } \mathrm{CO} 2 \mathrm{~g} / \\
100 \mathrm{~g} \text { dry corn } \\
\end{array}$ & $\begin{array}{c}\text { Drop } \\
\text { pH } \\
\end{array}$ & $\begin{array}{c}\text { Distill 1 } \\
\text { ABV } \\
(\%) \\
\end{array}$ & $\begin{array}{c}\text { Distill } 2 \\
\text { ABV (\%) } \\
\end{array}$ & $\begin{array}{c}\text { Avg } \\
\text { ABV } \\
(\%) \\
\end{array}$ & $\begin{array}{c}\text { Drop } \\
\text { Balling } \\
(\%) \\
\end{array}$ \\
\hline 27A9 & $12 / 19 / 2006$ & 3405 & 229 & 36.10 & 4.29 & 9.353 & 9.732 & 9.54 & 0.9 \\
\hline 27B9 & $12 / 19 / 2006$ & 3387 & 229 & 36.29 & 4.36 & 9.318 & 9.365 & 9.34 & 0.9 \\
\hline $27 \mathrm{C} 9$ & $12 / 19 / 2006$ & 3539 & 241 & 36.22 & 4.38 & 9.438 & 9.430 & 9.43 & 0.9 \\
\hline 27A 10 & $12 / 19 / 2006$ & 3274 & 225 & 36.92 & 4.73 & 9.641 & 9.628 & 9.63 & 0.9 \\
\hline 27B10 & $12 / 19 / 2006$ & 3260 & 225 & 37.11 & 4.69 & 9.615 & 9.609 & 9.61 & 0.9 \\
\hline $27 \mathrm{C} 10$ & $12 / 19 / 2006$ & 3382 & 234 & 36.97 & 4.68 & 9.680 & 9.653 & 9.67 & 0.9 \\
\hline 27A11 & $12 / 19 / 2006$ & 3216 & 213 & 35.78 & 4.59 & 9.253 & 9.257 & 9.26 & 0.9 \\
\hline 27B11 & $12 / 19 / 2006$ & 3241 & 217 & 36.04 & 4.61 & 9.247 & 9.262 & 9.25 & 0.6 \\
\hline $27 \mathrm{C} 11$ & $12 / 19 / 2006$ & 3174 & 209 & 35.78 & 4.62 & 9.192 & 9.204 & 9.20 & 0.6 \\
\hline 28A9 & $12 / 20 / 2006$ & 3244 & 212 & 35.46 & 4.36 & 9.212 & 9.211 & 9.21 & 0.6 \\
\hline 28B9 & $12 / 20 / 2006$ & 3333 & 220 & 35.68 & 4.41 & 9.210 & 9.210 & 9.21 & 0.9 \\
\hline $28 \mathrm{C} 9$ & $12 / 20 / 2006$ & 3465 & 229 & 35.44 & 4.46 & 9.263 & 9.292 & 9.28 & 0.9 \\
\hline 28A 10 & $12 / 20 / 2006$ & 3297 & 224 & 36.57 & 4.53 & 9.454 & 9.422 & 9.44 & 0.9 \\
\hline 28B10 & $12 / 20 / 2006$ & 3316 & 225 & 36.64 & 4.56 & 9.484 & 9.478 & 9.48 & 0.9 \\
\hline $28 \mathrm{C} 10$ & $12 / 20 / 2006$ & 3141 & 211 & 36.49 & 4.57 & 9.462 & 9.417 & 9.44 & 0.9 \\
\hline $28 \mathrm{~A} 11$ & $12 / 20 / 2006$ & 3298 & 218 & 35.59 & 4.38 & 9.305 & 9.278 & 9.29 & 0.9 \\
\hline 28B11 & $12 / 20 / 2006$ & 3415 & 225 & 35.54 & 4.43 & 9.278 & 9.212 & 9.25 & 1.2 \\
\hline $28 \mathrm{C} 11$ & $12 / 20 / 2006$ & 3473 & 231 & 35.74 & 4.44 & 9.307 & 9.262 & 9.28 & 1.2 \\
\hline
\end{tabular}




\section{TABLE VII}

HPLC DATA

\begin{tabular}{|c|c|c|c|c|c|c|c|c|c|c|c|c|}
\hline ID & $\begin{array}{c}\text { Highers } \\
\text { as } \\
\text { Maltose }\end{array}$ & Maltotriose & $\begin{array}{c}\text { Citric } \\
\text { Acid } \\
\end{array}$ & Maltose & Glucose & Fructose & $\begin{array}{c}\text { Succinic } \\
\text { Acid } \\
\end{array}$ & $\begin{array}{c}\text { Lactic } \\
\text { Acid } \\
\end{array}$ & Glycerol & $\begin{array}{c}\text { Acetic } \\
\text { Acid } \\
\end{array}$ & Ethanol & $\begin{array}{c}\text { Residual } \\
\text { sugars } \\
\text { as glucose } \\
\text { (PPM) } \\
\end{array}$ \\
\hline 1B9 & 7770 & 1030 & 700 & 960 & 240 & 410 & 549 & 200 & 5110 & 40 & 9.2 & 10533 \\
\hline $1 \mathrm{C} 9$ & 7850 & 940 & 640 & 1010 & 250 & 420 & 650 & 200 & 4960 & 40 & 9.2 & 10583 \\
\hline $1 \mathrm{~B} 10$ & 7500 & 370 & 170 & 1280 & 30 & 880 & 900 & 2120 & 4790 & 140 & 9.5 & 9669 \\
\hline $1 \mathrm{C} 10$ & 7500 & 390 & 170 & 1280 & 40 & 870 & 920 & 2140 & 4800 & 120 & 9.5 & 9700 \\
\hline $2 \mathrm{~A} 9$ & 9000 & 1020 & 320 & 1250 & 70 & 460 & 550 & 970 & 5250 & 40 & 9.6 & 11952 \\
\hline 2B9 & 8830 & 970 & 310 & 1180 & 50 & 450 & 550 & 790 & 5090 & 40 & 9.4 & 11626 \\
\hline $2 \mathrm{C} 9$ & 8840 & 1010 & 300 & 1240 & 60 & 460 & 550 & 820 & 5160 & 40 & 9.4 & 11753 \\
\hline $2 \mathrm{~B} 10$ & 8100 & 570 & 500 & 1230 & 320 & 630 & 550 & 260 & 4960 & 40 & 9.5 & 10752 \\
\hline $2 \mathrm{C} 10$ & 8100 & 560 & 510 & 1220 & 320 & 640 & 550 & 240 & 4920 & 30 & 9.5 & 10731 \\
\hline $3 \mathrm{~A} 9$ & 9480 & 1920 & 130 & 1440 & 240 & 110 & 590 & 2730 & 4890 & 320 & 8.3 & 13792 \\
\hline $3 \mathrm{~B} 9$ & 10450 & 2170 & 150 & 1700 & 240 & 140 & 670 & 2940 & 5460 & 340 & 9.3 & 15354 \\
\hline $3 \mathrm{C} 9$ & 10220 & 2160 & 140 & 1580 & 260 & 210 & 660 & 2950 & 5440 & 330 & 9.2 & 14995 \\
\hline $3 \mathrm{~A} 10$ & 9160 & 920 & 210 & 1290 & 30 & 380 & 650 & 3570 & 5170 & 180 & 9.6 & 12016 \\
\hline $3 \mathrm{~B} 10$ & 9730 & 1042 & 200 & 1500 & 20 & 360 & 640 & 3750 & 5180 & 200 & 9.5 & 12957 \\
\hline $3 \mathrm{C} 10$ & 9580 & 1000 & 200 & 1300 & 30 & 110 & 640 & 3710 & 5170 & 190 & 9.4 & 12554 \\
\hline 4A9 & 9180 & 1230 & 790 & 930 & 440 & 400 & 620 & 490 & 5430 & 30 & 9.5 & 12400 \\
\hline $4 \mathrm{~B} 9$ & 9370 & 1300 & 800 & 920 & 460 & 400 & 600 & 360 & 5430 & 20 & 9.4 & 12684 \\
\hline $4 \mathrm{C} 9$ & 8960 & 1260 & 800 & 890 & 450 & 390 & 620 & 350 & 5410 & 20 & 9.5 & 12168 \\
\hline $5 \mathrm{~A} 9$ & 10000 & 2068 & 950 & 0 & 40 & 470 & 450 & 400 & 5250 & 20 & 10.3 & 12782 \\
\hline $5 \mathrm{~B} 9$ & 9540 & 1930 & 850 & 0 & 40 & 420 & 400 & 450 & 5000 & 20 & 10.1 & 12150 \\
\hline $5 \mathrm{C} 9$ & 9600 & 1960 & 930 & 0 & 90 & 450 & 410 & 500 & 5070 & 50 & 10.2 & 12295 \\
\hline $5 \mathrm{~A} 10$ & 9640 & 1330 & 1090 & 0 & 30 & 560 & 420 & 350 & 5080 & 50 & 10.2 & 11602 \\
\hline $5 \mathrm{~B} 10$ & 9540 & 1220 & 1050 & 0 & 30 & 560 & 390 & 400 & 5080 & 50 & 10.3 & 11379 \\
\hline $5 \mathrm{C} 10$ & 9330 & 1220 & 1090 & 0 & 30 & 550 & 460 & 350 & 5140 & 40 & 10.3 & 11158 \\
\hline 6A9 & 10560 & 3730 & 940 & 60 & 70 & 310 & 460 & 2700 & 5180 & 400 & 8.7 & 15245 \\
\hline $6 \mathrm{~B} 9$ & 10980 & 3560 & 910 & 80 & 150 & 300 & 440 & 2650 & 5320 & 380 & 8.0 & 15606 \\
\hline $6 \mathrm{C} 9$ & 10890 & 3540 & 920 & 100 & 140 & 310 & 430 & 2670 & 5140 & 360 & 8.5 & 15501 \\
\hline $6 \mathrm{~A} 10$ & 10100 & 3220 & 910 & 600 & 110 & 460 & 460 & 2950 & 4990 & 450 & 8.5 & 14823 \\
\hline $6 \mathrm{~B} 10$ & 10440 & 2980 & 900 & 660 & 70 & 500 & 460 & 2780 & 5040 & 450 & 8.3 & 14947 \\
\hline $6 \mathrm{C} 10$ & 10020 & 2950 & 880 & 500 & 100 & 500 & 460 & 2770 & 5010 & 480 & 8.5 & 14334 \\
\hline $6 \mathrm{~A} 11$ & 10300 & 3060 & 700 & 640 & 80 & 440 & 520 & 2350 & 5220 & 360 & 8.9 & 14874 \\
\hline $6 \mathrm{~B} 11$ & 10100 & 3010 & 400 & 340 & 80 & 420 & 500 & 2380 & 5220 & 370 & 8.9 & 14294 \\
\hline $6 \mathrm{C} 11$ & 10100 & 3010 & 500 & 330 & 100 & 380 & 500 & 2270 & 5240 & 350 & 8.4 & 14304 \\
\hline
\end{tabular}


TABLE VII

HPLC DATA CONT.

\begin{tabular}{|c|c|c|c|c|c|c|c|c|c|c|c|}
\hline ID & $\begin{array}{c}\text { Highers } \\
\text { as } \\
\text { Maltose } \\
\end{array}$ & Maltotriose & $\begin{array}{c}\text { Citric } \\
\text { Acid } \\
\end{array}$ & Maltose & Glucose & Fructose & $\begin{array}{c}\begin{array}{c}\text { Succinic } \\
\text { Acid }\end{array} \\
\end{array}$ & $\begin{array}{c}\text { Lactic } \\
\text { Acid } \\
\end{array}$ & Glycerol & $\begin{array}{c}\text { Acetic } \\
\text { Acid } \\
\end{array}$ & Ethanol \\
\hline 7A9 & 9100 & 1330 & 1030 & 400 & 710 & 1550 & 980 & 1520 & 5470 & 80 & 9.4 \\
\hline 7B9 & 8690 & 1330 & 980 & 160 & 210 & 860 & 910 & 1500 & 5270 & 70 & 8.8 \\
\hline 7C9 & 8990 & 1340 & 1030 & 340 & 600 & 1430 & 970 & 1480 & 5440 & 80 & 8.8 \\
\hline 7A10 & 9038 & 1110 & 950 & 370 & 320 & 1180 & 980 & 3110 & 5210 & 140 & 8.5 \\
\hline 7B10 & 8890 & 1090 & 900 & 300 & 70 & 390 & 960 & 3090 & 5100 & 140 & 8.7 \\
\hline $7 \mathrm{C} 10$ & 9090 & 1080 & 900 & 300 & 60 & 340 & 950 & 3170 & 5140 & 170 & 7.7 \\
\hline 7A11 & 9250 & 2050 & 1367 & 100 & 100 & 720 & 970 & 1040 & 5410 & 80 & 9.2 \\
\hline 7B11 & 9090 & 1900 & 1580 & 0 & 100 & 630 & 970 & 790 & 5480 & 70 & 9.2 \\
\hline $7 \mathrm{C} 11$ & 8380 & 1892 & 1628 & 0 & 40 & 610 & 970 & 750 & 5440 & 60 & 9.2 \\
\hline $8 \mathrm{~A} 9$ & 8850 & 1240 & 1770 & 0 & 60 & 650 & 900 & 630 & 5230 & 60 & 8.7 \\
\hline $8 \mathrm{~B} 9$ & 8890 & 1290 & 1850 & 0 & 40 & 630 & 900 & 660 & 5270 & 60 & 8.3 \\
\hline $8 \mathrm{C} 9$ & 8830 & 1150 & 1870 & 0 & 50 & 630 & 900 & 700 & 5330 & 70 & 8.7 \\
\hline $8 \mathrm{~A} 10$ & 8840 & 840 & 880 & 300 & 10 & 150 & 830 & 3480 & 5020 & 200 & 8.7 \\
\hline $8 \mathrm{~B} 10$ & 8880 & 830 & 750 & 640 & 20 & 300 & 850 & 3550 & 5060 & 200 & 8.8 \\
\hline $8 \mathrm{C} 10$ & 8800 & 830 & 840 & 310 & 10 & 300 & 800 & 3590 & 4970 & 200 & 8.6 \\
\hline $8 \mathrm{~A} 11$ & 9010 & 2000 & 1930 & 0 & 440 & 600 & 830 & 320 & 5660 & 60 & 8.9 \\
\hline $8 \mathrm{~B} 11$ & 8650 & 1900 & 1850 & 0 & 400 & 570 & 800 & 360 & 5460 & 60 & 8.4 \\
\hline $8 \mathrm{C} 11$ & 9120 & 1940 & 1930 & 0 & 516 & 630 & 820 & 310 & 5480 & 60 & 8.6 \\
\hline 9A9 & 9230 & 2310 & 720 & 210 & 260 & 680 & 910 & 1640 & 5700 & 100 & 8.4 \\
\hline $9 \mathrm{~B} 9$ & 9840 & 2180 & 750 & 280 & 260 & 690 & 910 & 1620 & 5560 & 110 & 8.3 \\
\hline $9 \mathrm{C} 9$ & 9660 & 2330 & 750 & 320 & 270 & 690 & 940 & 1710 & 5760 & 120 & 8.6 \\
\hline 9A10 & 9470 & 1270 & 810 & 340 & 190 & 1050 & 790 & 2370 & 5750 & 210 & 8.7 \\
\hline 9B10 & 8990 & 1100 & 800 & 280 & 20 & 810 & 1000 & 2310 & 5490 & 210 & 8.7 \\
\hline $9 \mathrm{C} 10$ & 8440 & 1110 & 800 & 300 & 210 & 1030 & 980 & 2300 & 5460 & 220 & 8.7 \\
\hline 9A11 & 8940 & 1400 & 760 & 270 & 120 & 860 & 1050 & 1830 & 5730 & 180 & 8.6 \\
\hline 9B11 & 9020 & 1190 & 770 & 330 & 285 & 1090 & 960 & 1880 & 5660 & 150 & 8.6 \\
\hline $9 \mathrm{C} 11$ & 9330 & 1290 & 810 & 300 & 260 & 1070 & 1000 & 1950 & 5840 & 150 & 8.6 \\
\hline $10 \mathrm{~A} 9$ & 9240 & 2503 & * & 0 & 140 & 710 & 1040 & 510 & 5620 & 60 & 8.6 \\
\hline 10B9 & 9350 & 2310 & * & 0 & 70 & 720 & 1000 & 420 & 5440 & 60 & 9.3 \\
\hline $10 \mathrm{C} 9$ & 8620 & 1740 & $*$ & $*$ & 170 & 810 & 1010 & 420 & 5400 & 60 & 8.9 \\
\hline $10 \mathrm{~A} 10$ & 8590 & 1700 & $*$ & 0 & 170 & 780 & 1100 & 290 & 5600 & 60 & 8.9 \\
\hline 10B10 & 8880 & 1860 & $*$ & 0 & 130 & 760 & 1020 & 340 & 5500 & 50 & 8.8 \\
\hline $10 \mathrm{C} 10$ & 9360 & 1690 & $*$ & 0 & 40 & 760 & 1050 & 340 & 5480 & 50 & 8.9 \\
\hline $10 \mathrm{~A} 11$ & 9400 & 2200 & $*$ & 0 & 160 & 840 & 990 & 340 & 5460 & 50 & 8.9 \\
\hline 10B11 & 9700 & 1950 & $*$ & 0 & 240 & 970 & 1000 & 350 & 5490 & 50 & 9.0 \\
\hline $10 \mathrm{C} 11$ & 9500 & 2100 & $*$ & 0 & 30 & 760 & 1000 & 360 & 5470 & 50 & 9.0 \\
\hline $11 \mathrm{~A} 9$ & 9040 & 1420 & * & $*$ & 160 & 640 & 330 & 360 & 5460 & $*$ & 9.0 \\
\hline 11B9 & 9170 & 1540 & * & $*$ & 200 & 550 & 370 & 330 & 5330 & $*$ & 8.8 \\
\hline $11 \mathrm{C} 9$ & 8770 & 1520 & $*$ & $*$ & 350 & 520 & 370 & 320 & 5300 & $*$ & 8.9 \\
\hline $11 \mathrm{~A} 10$ & 8944 & 1220 & * & $*$ & 190 & 750 & 320 & 840 & 5280 & $*$ & 9.9 \\
\hline $11 \mathrm{~B} 10$ & 8898 & 1200 & * & $*$ & 90 & 700 & 480 & 770 & 5270 & $*$ & 10.0 \\
\hline $11 \mathrm{C} 10$ & 8920 & 1220 & * & $*$ & 170 & 690 & 350 & 940 & 5290 & $*$ & 9.6 \\
\hline
\end{tabular}


TABLE VII

HPLC DATA CONT.

\begin{tabular}{|c|c|c|c|c|c|c|c|c|c|c|c|}
\hline ID & $\begin{array}{c}\text { Highers } \\
\text { as } \\
\text { Maltose } \\
\end{array}$ & Maltotriose & $\begin{array}{c}\text { Citric } \\
\text { Acid } \\
\end{array}$ & Maltose & Glucose & Fructose & $\begin{array}{c}\text { Succinic } \\
\text { Acid }\end{array}$ & $\begin{array}{c}\text { Lactic } \\
\text { Acid } \\
\end{array}$ & Glycerol & $\begin{array}{c}\text { Acetic } \\
\text { Acid } \\
\end{array}$ & Ethanol \\
\hline $12 \mathrm{~A} 9$ & 9050 & 1600 & $*$ & $*$ & 110 & 490 & 420 & 340 & 5380 & $*$ & 8.9 \\
\hline $12 \mathrm{~B} 9$ & 8800 & 1560 & $*$ & $*$ & 190 & 490 & 390 & 330 & 5200 & $*$ & 9.4 \\
\hline $12 \mathrm{C} 9$ & 8900 & 1600 & $*$ & $*$ & 190 & 500 & 400 & 350 & 5240 & $*$ & 9.0 \\
\hline $12 \mathrm{~A} 10$ & 8730 & 1280 & $*$ & $*$ & 100 & 800 & 340 & 400 & 5080 & $*$ & 9.6 \\
\hline $12 \mathrm{~B} 10$ & 9040 & 1340 & $*$ & $*$ & 110 & 790 & 350 & 420 & 5160 & $*$ & 9.6 \\
\hline $12 \mathrm{C} 10$ & 8950 & 1350 & $*$ & $*$ & 170 & 600 & 340 & 440 & 5140 & $*$ & 9.5 \\
\hline $13 \mathrm{~A} 9$ & 8010 & 570 & 20 & 120 & 260 & 660 & 430 & 4950 & 4400 & 550 & 8.2 \\
\hline 13B9 & 7880 & 560 & 20 & 110 & 100 & 550 & 420 & 5000 & 4300 & 580 & 8.3 \\
\hline $13 \mathrm{C} 9$ & 7870 & 600 & 30 & 130 & 90 & 400 & 420 & 5170 & 4330 & 550 & 8.4 \\
\hline $13 \mathrm{~A} 10$ & 7830 & 200 & 20 & 130 & 70 & 530 & 470 & 4590 & 4520 & 430 & 8.0 \\
\hline $13 \mathrm{~B} 10$ & 7790 & 470 & 10 & 100 & 40 & 460 & 520 & 4180 & 4620 & 360 & 7.6 \\
\hline $13 \mathrm{C} 10$ & 7650 & 440 & 10 & 90 & 60 & 560 & 450 & 4300 & 4414 & 380 & 8.5 \\
\hline $13 \mathrm{~A} 11$ & 8080 & 1460 & 10 & 270 & 20 & 270 & 560 & 1600 & 6200 & 200 & 8.8 \\
\hline 13B11 & 8200 & 1480 & 20 & 460 & 70 & 390 & 590 & 1570 & 6200 & 180 & 8.7 \\
\hline $13 \mathrm{C} 11$ & 8200 & 1480 & 50 & 300 & 70 & 390 & 600 & 1550 & 6300 & 180 & 8.0 \\
\hline $14 \mathrm{~A} 9$ & 7800 & 920 & 80 & 490 & 340 & 380 & 590 & 400 & 5350 & 80 & 9.0 \\
\hline 14B9 & 7520 & 530 & 80 & 80 & 100 & 650 & 420 & $5000 *$ & 4350 & $570 *$ & 8.3 \\
\hline $14 \mathrm{C} 9$ & 7700 & 900 & 80 & 400 & 110 & 600 & 400 & 450 & 5260 & 90 & 8.9 \\
\hline $14 \mathrm{~A} 10$ & 6400 & 840 & 80 & 290 & 1010 & 680 & 500 & 530 & 5170 & 90 & 9.0 \\
\hline $14 \mathrm{~B} 10$ & 6470 & 760 & 80 & 290 & 1030 & 980 & 500 & 400 & 5150 & 80 & 9.2 \\
\hline $14 \mathrm{C} 10$ & 6380 & 760 & 80 & 290 & 1020 & 980 & 500 & 480 & 5160 & 90 & 9.2 \\
\hline $15 \mathrm{~A} 9$ & 7070 & 670 & 180 & 310 & 1010 & 570 & 460 & 380 & 4760 & 90 & 9.1 \\
\hline 15B9 & 7200 & 600 & 170 & 300 & 980 & 580 & 460 & 390 & 4700 & 90 & 8.9 \\
\hline $15 \mathrm{C} 9$ & 6820 & 600 & 160 & 290 & 990 & 800 & 450 & 370 & 4660 & 90 & 8.9 \\
\hline $15 \mathrm{~A} 10$ & 7010 & 390 & 10 & 150 & 1040 & 540 & 580 & 1730 & 4820 & 140 & 9.0 \\
\hline $15 \mathrm{~B} 10$ & 7280 & 400 & 5 & 150 & 1080 & 670 & 610 & 2150 & 4920 & 220 & 7.9 \\
\hline $15 \mathrm{C} 10$ & 7100 & 380 & 20 & 110 & 1090 & 460 & 660 & 1880 & 4860 & 150 & 8.9 \\
\hline $16 \mathrm{~A} 9$ & 7620 & 1430 & 5 & 640 & 1300 & 570 & 440 & 1580 & 5660 & 100 & 9.0 \\
\hline 16B9 & 7580 & 1190 & 30 & 410 & 1060 & 450 & 440 & 1460 & 5400 & 90 & 8.6 \\
\hline $16 \mathrm{C} 9$ & 7580 & 1340 & 30 & 440 & 1010 & 440 & 430 & 1550 & 5520 & 80 & 8.1 \\
\hline $16 \mathrm{~A} 10$ & 7690 & 1000 & 190 & 520 & 1090 & 900 & 460 & 330 & 5440 & 50 & 8.7 \\
\hline $16 \mathrm{~B} 10$ & 7910 & 940 & 190 & 540 & 1090 & 1320 & 460 & 300 & 5530 & 50 & 9.0 \\
\hline $16 \mathrm{C} 10$ & 7820 & 920 & 180 & 510 & 1100 & 1120 & 460 & 290 & 5500 & 50 & 8.9 \\
\hline 16A11 & 8130 & 1690 & 60 & 530 & 980 & 300 & 520 & 2370 & 5660 & 200 & 8.1 \\
\hline 16B11 & 8160 & 1920 & 60 & 540 & 1000 & 310 & 530 & 2510 & 5690 & 230 & 8.0 \\
\hline $16 \mathrm{C} 11$ & 8170 & 2010 & 40 & 610 & 1000 & 340 & 520 & 2620 & 5720 & 240 & 7.1 \\
\hline 17A9 & 8920 & 1410 & 40 & 1060 & 670 & 480 & 570 & 540 & 5690 & 50 & 9.3 \\
\hline 17B9 & 8870 & 1240 & 180 & 900 & 660 & 530 & 560 & 430 & 5480 & 50 & 9.3 \\
\hline $17 \mathrm{C} 9$ & 8610 & 1280 & 220 & 890 & 570 & 370 & 530 & 360 & 5400 & 50 & 9.3 \\
\hline $17 \mathrm{~A} 10$ & 8670 & 1270 & 220 & 890 & 550 & 380 & 540 & 380 & 5550 & 40 & 9.4 \\
\hline $17 \mathrm{~B} 10$ & 8780 & 1230 & 240 & 730 & 610 & 480 & 560 & 420 & 5600 & 40 & 9.2 \\
\hline $17 \mathrm{C} 10$ & 8570 & 1160 & 210 & 890 & 520 & 390 & 570 & 370 & 5510 & 50 & 9.3 \\
\hline
\end{tabular}




\section{TABLE VII}

HPLC DATA CONT.

\begin{tabular}{|c|c|c|c|c|c|c|c|c|c|c|c|}
\hline ID & $\begin{array}{c}\text { Highers } \\
\text { as } \\
\text { Maltose }\end{array}$ & Maltotriose & $\begin{array}{c}\text { Citric } \\
\text { Acid } \\
\end{array}$ & Maltose & Glucose & Fructose & $\begin{array}{c}\text { Succinic } \\
\text { Acid } \\
\end{array}$ & $\begin{array}{c}\text { Lactic } \\
\text { Acid }\end{array}$ & Glycerol & $\begin{array}{c}\text { Acetic } \\
\text { Acid }\end{array}$ & Ethanol \\
\hline $18 \mathrm{~A} 9$ & 9100 & 1690 & 50 & 900 & 140 & 580 & 600 & 2250 & 5790 & 150 & 9.2 \\
\hline 18B9 & 8720 & 1620 & 30 & 890 & 110 & 340 & 550 & 2130 & 5620 & 140 & 9.0 \\
\hline $18 \mathrm{C} 9$ & 9000 & 1580 & 30 & 790 & 70 & 320 & 550 & 2140 & 5590 & 150 & 8.8 \\
\hline $18 \mathrm{~A} 10$ & 8800 & 970 & 20 & 730 & 100 & 750 & 580 & 2180 & 5640 & 160 & 8.9 \\
\hline 18B10 & 8690 & 950 & 30 & 850 & 60 & 450 & 560 & 2200 & 5660 & 170 & 8.9 \\
\hline $18 \mathrm{C} 10$ & 8780 & 920 & 30 & 710 & 70 & 720 & 560 & 2270 & 5620 & 170 & 8.8 \\
\hline $18 \mathrm{~A} 11$ & 9090 & 1650 & 40 & 680 & 120 & 380 & 580 & 2300 & 5600 & 230 & 8.6 \\
\hline 18B11 & 9030 & 1700 & 40 & 840 & 130 & 360 & 680 & 2400 & 5700 & 230 & 8.5 \\
\hline $18 \mathrm{C} 11$ & 8950 & 1900 & 40 & 920 & 200 & 390 & 720 & 2520 & 5780 & 250 & 8.8 \\
\hline 19A9 & 8510 & 1025 & 830 & 930 & ND & 180 & 1020 & 400 & 5350 & 20 & 9.7 \\
\hline 19B9 & 8460 & 990 & 620 & 1040 & ND & 260 & 1020 & 350 & 5230 & 50 & 9.6 \\
\hline $19 \mathrm{C} 9$ & 8320 & 1000 & 670 & 1020 & 100 & 200 & 970 & 320 & 5260 & 60 & 9.6 \\
\hline 19A10 & 8720 & 830 & 530 & 1130 & 100 & 280 & 460 & 310 & 5200 & 60 & 9.7 \\
\hline 19B10 & 8320 & 860 & 530 & 1180 & 160 & 340 & 470 & 350 & 5270 & 70 & 9.7 \\
\hline $19 \mathrm{C} 10$ & 8290 & 860 & 550 & 1190 & 310 & 620 & 1102 & 350 & 5260 & 60 & 9.7 \\
\hline
\end{tabular}


TABLE VIII

GC DATA

\begin{tabular}{|c|c|c|c|c|c|c|c|c|}
\hline ID & Acetaldehyde & Methanol & $\begin{array}{c}\text { Ethyl } \\
\text { Acetate }\end{array}$ & $\begin{array}{c}\text { n-Propyl } \\
\text { Alcohol } \\
\end{array}$ & $\begin{array}{l}\text { Isobutyl } \\
\text { Alcohol } \\
\end{array}$ & $\begin{array}{c}\text { Isoamyl } \\
\text { Alcohol \#1 } \\
\end{array}$ & $\begin{array}{c}\text { Isoamyl } \\
\text { Alcohol \#2 } \\
\end{array}$ & $\begin{array}{c}\text { Total Fusel Oils } \\
\text { @ } 100 \text { proof } \\
\end{array}$ \\
\hline $1 \mathrm{~A} 9$ & 2.272 & 0.001 & 1.621 & 2.795 & 19.444 & 13.437 & 25.224 & 324 \\
\hline 1B9 & 2.816 & 0.000 & 1.630 & 2.930 & 20.084 & 13.877 & 25.249 & 326 \\
\hline $1 \mathrm{C} 9$ & 2.622 & 0.000 & 1.569 & 2.785 & 19.618 & 13.432 & 24.520 & 320 \\
\hline $1 \mathrm{~A} 10$ & 2.285 & 0.001 & 2.224 & 2.958 & 20.941 & 12.179 & 30.796 & 344 \\
\hline 1B10 & 0.518 & 0.001 & 2.258 & 2.969 & 21.238 & 12.368 & 31.077 & 354 \\
\hline $1 \mathrm{C} 10$ & 0.737 & 0.000 & 2.624 & 3.485 & 25.758 & 15.028 & 38.303 & 433 \\
\hline $2 \mathrm{~A} 9$ & 0.955 & 0.001 & 1.883 & 3.360 & 17.489 & 13.449 & 26.707 & 319 \\
\hline 2B9 & 1.574 & 0.001 & 1.960 & 3.450 & 17.547 & 13.535 & 27.082 & 322 \\
\hline $2 \mathrm{C} 9$ & 1.364 & 0.001 & 1.837 & 3.391 & 16.829 & 13.003 & 26.187 & 312 \\
\hline $2 \mathrm{~A} 10$ & 2.445 & 0.001 & 2.143 & 3.380 & 22.034 & 14.453 & 26.674 & 346 \\
\hline 2B10 & 1.577 & 0.001 & 1.969 & 3.273 & 21.793 & 14.316 & 26.150 & 336 \\
\hline $2 \mathrm{C} 10$ & 2.113 & 0.001 & 2.034 & 3.364 & 21.878 & 14.379 & 26.263 & 339 \\
\hline $3 \mathrm{~A} 9$ & 1.060 & 0.000 & 1.409 & 1.353 & 9.261 & 7.490 & 30.193 & 259 \\
\hline 3B9 & 1.389 & 0.000 & 1.543 & 1.464 & 9.680 & 7.778 & 31.163 & 270 \\
\hline 3C9 & 1.371 & 0.000 & 1.472 & 1.417 & 9.549 & 7.748 & 31.028 & 267 \\
\hline $3 \mathrm{~A} 10$ & 3.061 & 0.000 & 1.514 & 2.089 & 9.838 & 7.274 & 27.930 & 249 \\
\hline 3B10 & 2.696 & 0.000 & 1.563 & 2.115 & 9.841 & 7.315 & 28.374 & 251 \\
\hline $3 \mathrm{C} 10$ & 2.499 & 0.001 & 1.560 & 2.111 & 9.989 & 7.378 & 28.569 & 255 \\
\hline $4 \mathrm{~A} 9$ & 1.595 & 0.000 & 1.591 & 2.936 & 18.819 & 14.530 & 27.083 & 336 \\
\hline $4 \mathrm{~B} 9$ & 1.812 & 0.001 & 1.796 & 3.129 & 19.795 & 15.333 & 28.426 & 353 \\
\hline 4C9 & 2.217 & 0.000 & 1.649 & 3.051 & 19.079 & 14.785 & 27.524 & 339 \\
\hline $4 \mathrm{~A} 10$ & 1.853 & 0.000 & 1.970 & 3.303 & 22.088 & 14.583 & 26.225 & 339 \\
\hline 4B10 & 3.885 & 0.000 & 2.000 & 3.402 & 22.398 & 14.798 & 26.727 & 347 \\
\hline $5 \mathrm{~A} 9$ & 1.538 & 0.001 & 2.863 & 3.449 & 21.679 & 14.612 & 31.135 & 338 \\
\hline $5 \mathrm{~B} 9$ & 1.033 & 0.000 & 2.353 & 3.071 & 19.509 & 13.094 & 28.103 & 309 \\
\hline $5 \mathrm{C} 9$ & 0.694 & 0.000 & 2.457 & 3.128 & 19.632 & 13.192 & 28.238 & 310 \\
\hline $5 \mathrm{~A} 10$ & 1.392 & 0.001 & 2.641 & 3.303 & 19.310 & 13.148 & 28.980 & 310 \\
\hline $5 \mathrm{~B} 10$ & 2.100 & 0.000 & 2.790 & 3.357 & 19.564 & 13.292 & 29.918 & 317 \\
\hline $5 \mathrm{C} 10$ & 1.496 & 0.001 & 2.955 & 3.406 & 19.764 & 13.448 & 30.435 & 320 \\
\hline $6 \mathrm{~A} 9$ & 0.878 & 0.000 & 1.482 & 1.492 & 11.720 & 7.305 & 28.132 & 279 \\
\hline $6 \mathrm{~B} 9$ & 1.356 & 0.001 & 1.611 & 1.635 & 12.315 & 7.872 & 29.505 & 294 \\
\hline $6 \mathrm{C} 9$ & 0.958 & 0.000 & 1.481 & 1.514 & 11.866 & 7.581 & 28.495 & 285 \\
\hline $6 \mathrm{~A} 10$ & 0.352 & 0.000 & 1.511 & 1.391 & 10.297 & 6.339 & 24.107 & 247 \\
\hline $6 \mathrm{~B} 10$ & 2.682 & 0.001 & 2.139 & 2.043 & 14.542 & 9.016 & 33.832 & 347 \\
\hline $6 \mathrm{C} 10$ & 0.665 & 0.000 & 1.692 & 1.584 & 11.571 & 7.142 & 26.461 & 270 \\
\hline $6 \mathrm{~A} 11$ & 1.632 & 0.004 & 1.949 & 2.023 & 14.630 & 9.497 & 34.007 & 337 \\
\hline 6B11 & 1.300 & 0.000 & 1.637 & 1.691 & 12.253 & 7.918 & 28.362 & 282 \\
\hline $6 \mathrm{C} 11$ & 0.535 & 0.000 & 1.585 & 1.652 & 12.092 & 7.830 & 28.141 & 277 \\
\hline
\end{tabular}


TABLE VIII

GC DATA CONT.

\begin{tabular}{|c|c|c|c|c|c|c|c|c|}
\hline ID & Acetaldehyde & Methanol & $\begin{array}{c}\text { Ethyl } \\
\text { Acetate } \\
\end{array}$ & $\begin{array}{c}\text { n-Propyl } \\
\text { Alcohol } \\
\end{array}$ & $\begin{array}{l}\text { Isobutyl } \\
\text { Alcohol } \\
\end{array}$ & $\begin{array}{c}\text { Isoamyl } \\
\text { Alcohol \#1 } \\
\end{array}$ & $\begin{array}{c}\text { Isoamyl } \\
\text { Alcohol \#2 } \\
\end{array}$ & $\begin{array}{c}\text { Total Fusel } \\
\text { Oils @ 100 } \\
\text { proof } \\
\end{array}$ \\
\hline 7A9 & 0.000 & 0.000 & 1.870 & 3.011 & 16.904 & 14.321 & 30.229 & 342 \\
\hline $7 \mathrm{~B} 9$ & 0.361 & 0.000 & 1.818 & 2.939 & 16.658 & 14.175 & 29.881 & 337 \\
\hline 7C9 & 0.000 & 0.000 & 1.795 & 2.915 & 16.631 & 14.089 & 30.264 & 338 \\
\hline 7A10 & 0.000 & 0.000 & 1.430 & 2.051 & 12.967 & 10.062 & 31.162 & 316 \\
\hline $7 \mathrm{~B} 10$ & 0.000 & 0.000 & 1.889 & 2.727 & 17.276 & 13.404 & 41.499 & 425 \\
\hline $7 \mathrm{C} 10$ & 0.000 & 0.000 & 1.226 & 2.007 & 13.368 & 10.286 & 32.122 & 326 \\
\hline 7A11 & 0.000 & 0.000 & 2.041 & 3.436 & 21.758 & 19.056 & 33.543 & 423 \\
\hline 7B11 & 0.000 & 0.000 & 1.668 & 2.809 & 17.590 & 15.319 & 27.057 & 342 \\
\hline $7 \mathrm{C} 11$ & 0.000 & 0.000 & 1.607 & 2.773 & 17.809 & 15.536 & 27.232 & 343 \\
\hline $8 \mathrm{~A} 9$ & 0.000 & 0.000 & 1.746 & 2.688 & 15.957 & 14.940 & 28.775 & 354 \\
\hline $8 \mathrm{~B} 9$ & 1.027 & 0.000 & 1.712 & 2.620 & 15.419 & 14.393 & 27.730 & 343 \\
\hline $8 \mathrm{C} 9$ & 0.971 & 0 & 1.718 & 2.7145 & 15.7545 & 14.6615 & 28.662 & 351 \\
\hline $8 \mathrm{~A} 10$ & 3.540 & 0.000 & 1.708 & 2.556 & 14.834 & 11.078 & 32.218 & 342 \\
\hline $8 \mathrm{~B} 10$ & 0.131 & 0.000 & 1.674 & 2.404 & 14.523 & 10.653 & 32.733 & 339 \\
\hline $8 \mathrm{C} 10$ & 3.008 & 0 & 1.509 & 2.32 & 13.8655 & 10.2095 & 30.923 & 322 \\
\hline 8A11 & 0.955 & 0.000 & 1.813 & 3.097 & 18.655 & 15.194 & 28.301 & 366 \\
\hline $8 \mathrm{~B} 11$ & 1.318 & 0.000 & 1.896 & 3.182 & 18.823 & 15.270 & 28.528 & 369 \\
\hline $8 \mathrm{C} 11$ & 1.0705 & 0 & 1.8005 & 3.021 & 18.017 & 14.6035 & 27.32 & 352 \\
\hline 9A9 & 0.414 & 0.000 & 1.557 & 2.141 & 11.452 & 11.029 & 27.660 & 334 \\
\hline $9 \mathrm{~B} 9$ & 0.595 & 0.000 & 1.720 & 2.461 & 12.691 & 12.318 & 30.927 & 329 \\
\hline 9C9 & 0.257 & 0.000 & 1.588 & 2.288 & 12.596 & 12.057 & 30.579 & 322 \\
\hline 9A10 & 1.521 & 0.000 & 1.577 & 1.665 & 12.142 & 8.993 & 31.208 & 302 \\
\hline 9B10 & 1.286 & 0.000 & 1.576 & 1.698 & 12.222 & 9.077 & 31.450 & 307 \\
\hline $9 \mathrm{C} 10$ & 1.206 & 0.000 & 1.590 & 1.674 & 12.069 & 8.843 & 30.799 & 299 \\
\hline 9A11 & 0.680 & 0.000 & 1.631 & 2.116 & 12.952 & 10.452 & 32.123 & 328 \\
\hline $9 \mathrm{~B} 11$ & 0.435 & 0.000 & 1.680 & 2.118 & 12.824 & 10.417 & 31.815 & 303 \\
\hline $9 \mathrm{C} 11$ & 0.332 & 0.000 & 1.702 & 2.107 & 12.565 & 10.097 & 30.905 & 290 \\
\hline $10 \mathrm{~A} 9$ & 0.318 & 0.000 & 1.577 & 2.546 & 15.616 & 14.357 & 25.277 & 316 \\
\hline 10B9 & 0.990 & 0.000 & 1.575 & 2.578 & 15.710 & 14.429 & 25.330 & 320 \\
\hline $10 \mathrm{C} 9$ & 0.456 & 0.000 & 1.685 & 2.578 & 15.469 & 14.281 & 25.382 & 318 \\
\hline $10 \mathrm{~A} 10$ & 0.504 & 0.000 & 1.750 & 2.740 & 16.592 & 14.265 & 25.469 & 325 \\
\hline 10B10 & 0.571 & 0.000 & 1.791 & 2.760 & 16.692 & 14.354 & 25.651 & 327 \\
\hline $10 \mathrm{C} 10$ & 0.516 & 0.000 & 1.784 & 2.732 & 16.443 & 14.137 & 25.276 & 324 \\
\hline 10A11 & 1.122 & 0.000 & 1.578 & 2.641 & 17.276 & 14.612 & 25.844 & 331 \\
\hline 10B11 & 0.642 & 0.000 & 1.565 & 2.536 & 16.706 & 14.112 & 25.012 & 323 \\
\hline $10 \mathrm{C} 11$ & 0.000 & 0.000 & 1.640 & 2.593 & 17.177 & 14.520 & 25.648 & 327 \\
\hline $11 \mathrm{~A} 9$ & 1.850 & 0.000 & 1.628 & 2.641 & 14.828 & 13.208 & 27.473 & 317 \\
\hline 11B9 & 1.839 & 0.000 & 1.536 & 2.427 & 13.661 & 12.175 & 25.497 & 296 \\
\hline $11 \mathrm{C} 9$ & 2.172 & 0.000 & 1.596 & 2.558 & 14.191 & 12.611 & 26.178 & 303 \\
\hline $11 \mathrm{~A} 10$ & 2.017 & 0.001 & 2.165 & 3.388 & 16.970 & 13.314 & 26.870 & 300 \\
\hline $11 \mathrm{~B} 10$ & 2.094 & 0.001 & 2.192 & 3.445 & 17.340 & 13.580 & 27.362 & 307 \\
\hline $11 \mathrm{C} 10$ & 1.831 & 0.001 & 2.221 & 3.435 & 17.388 & 13.626 & 27.361 & 306 \\
\hline
\end{tabular}


TABLE VIII

GC DATA CONT.

\begin{tabular}{|c|c|c|c|c|c|c|c|c|}
\hline ID & Acetaldehyde & Methanol & $\begin{array}{c}\text { Ethyl } \\
\text { Acetate }\end{array}$ & $\begin{array}{c}\text { n-Propyl } \\
\text { Alcohol } \\
\end{array}$ & $\begin{array}{l}\text { Isobutyl } \\
\text { Alcohol } \\
\end{array}$ & $\begin{array}{c}\text { Isoamyl } \\
\text { Alcohol \#1 } \\
\end{array}$ & $\begin{array}{c}\text { Isoamyl } \\
\text { Alcohol \#2 } \\
\end{array}$ & $\begin{array}{c}\text { Total Fusel } \\
\text { Oils @ 100 } \\
\text { proof } \\
\end{array}$ \\
\hline $12 \mathrm{~A} 9$ & 1.998 & 0.000 & 1.843 & 3.302 & 19.447 & 76.340 & 28.702 & 667 \\
\hline 12B9 & 1.966 & 0.000 & 1.614 & 2.895 & 16.903 & 12.355 & 24.925 & 296 \\
\hline $12 \mathrm{C} 9$ & 1.414 & 0.000 & 1.613 & 3.093 & 18.389 & 13.471 & 27.225 & 323 \\
\hline $12 \mathrm{~A} 10$ & 1.710 & 0.000 & 1.987 & 3.518 & 19.781 & 13.802 & 27.721 & 332 \\
\hline $12 \mathrm{~B} 10$ & 0.929 & 0.000 & 1.936 & 3.517 & 20.037 & 13.941 & 27.869 & 334 \\
\hline $12 \mathrm{C} 10$ & 1.665 & 0.000 & 1.919 & 3.370 & 19.018 & 13.234 & 26.353 & 316 \\
\hline $13 \mathrm{~A} 9$ & 0.000 & 0.000 & 1.173 & 0.921 & 8.771 & 5.374 & 18.514 & 205 \\
\hline 13B9 & 0.000 & 0.000 & 1.364 & 0.975 & 9.347 & 5.607 & 18.811 & 208 \\
\hline $13 \mathrm{C} 9$ & 0.000 & 0.000 & 1.357 & 0.963 & 8.893 & 5.368 & 18.022 & 199 \\
\hline $13 \mathrm{~A} 10$ & 0.000 & 0.000 & 1.387 & 1.062 & 10.620 & 6.279 & 21.141 & 229 \\
\hline 13B10 & 0.000 & 0.000 & 1.320 & 1.227 & 10.906 & 6.711 & 23.515 & 254 \\
\hline $13 \mathrm{C} 10$ & 0.000 & 0.000 & 1.641 & 1.158 & 11.044 & 6.494 & 21.495 & 233 \\
\hline 13A11 & 0.706 & 0.003 & 1.871 & 2.350 & 14.388 & 12.464 & 33.175 & 351 \\
\hline 13B11 & 0.000 & 0.000 & 1.663 & 2.165 & 13.663 & 11.673 & 31.588 & 333 \\
\hline $13 \mathrm{C} 11$ & 0.667 & 0.000 & 1.913 & 2.397 & 14.579 & 12.626 & 32.869 & 350 \\
\hline $14 \mathrm{~A} 9$ & 0.000 & 0.000 & 1.182 & 2.773 & 16.444 & 12.527 & 23.763 & 308 \\
\hline 14B9 & 0.000 & 0.000 & 1.228 & 2.836 & 16.959 & 12.975 & 24.507 & 308 \\
\hline $14 \mathrm{C} 9$ & 0.000 & 0.000 & 1.291 & 2.764 & 16.941 & 12.950 & 24.531 & 307 \\
\hline $14 \mathrm{~A} 10$ & 0.000 & 0.000 & 1.321 & 2.852 & 17.860 & 12.832 & 24.518 & 307 \\
\hline 14B10 & 0.000 & 0.000 & 1.416 & 2.968 & 18.056 & 13.013 & 24.921 & 309 \\
\hline $14 \mathrm{C} 10$ & 0.000 & 0.000 & 1.377 & 2.887 & 18.128 & 13.026 & 24.873 & 310 \\
\hline $15 \mathrm{~A} 9$ & 0.000 & 0.000 & 1.549 & 2.615 & 19.741 & 12.589 & 23.456 & 322 \\
\hline 15B9 & 0.000 & 0.000 & 1.536 & 2.607 & 19.586 & 12.461 & 23.334 & 319 \\
\hline $15 \mathrm{C} 9$ & 1.626 & 0.000 & 1.594 & 2.645 & 19.855 & 12.653 & 23.512 & 320 \\
\hline $15 \mathrm{~A} 10$ & 1.667 & 0.000 & 1.620 & 2.030 & 12.043 & 8.342 & 27.019 & 271 \\
\hline $15 \mathrm{~B} 10$ & 0.000 & 0.000 & 1.582 & 1.847 & 11.571 & 7.792 & 27.146 & 267 \\
\hline $15 \mathrm{C} 10$ & 0.000 & 0.000 & 1.499 & 2.160 & 12.426 & 8.544 & 26.079 & 268 \\
\hline $16 \mathrm{~A} 9$ & 0.000 & 0.000 & 1.664 & 2.491 & 13.981 & 12.574 & 29.849 & 332 \\
\hline 16B9 & 0.000 & 0.000 & 1.776 & 2.663 & 14.104 & 12.766 & 28.592 & 328 \\
\hline $16 \mathrm{C} 9$ & 0.000 & 0.000 & 1.706 & 2.546 & 14.057 & 12.641 & 30.530 & 336 \\
\hline $16 \mathrm{~A} 10$ & 0.222 & 0.000 & 1.818 & 2.922 & 16.789 & 14.200 & 27.722 & 337 \\
\hline $16 \mathrm{~B} 10$ & 0.895 & 0.000 & 1.808 & 3.056 & 17.050 & 14.435 & 27.965 & 340 \\
\hline $16 \mathrm{C} 10$ & 0.523 & 0.001 & 2.130 & 3.263 & 17.785 & 15.026 & 29.253 & 357 \\
\hline $16 \mathrm{~A} 11$ & 1.160 & 0.000 & 1.273 & 1.636 & 10.348 & 8.831 & 30.988 & 298 \\
\hline 16B11 & 0.986 & 0.000 & 1.274 & 1.542 & 10.385 & 8.722 & 30.972 & 295 \\
\hline $16 \mathrm{C} 11$ & 0.278 & 0.000 & 1.069 & 1.428 & 9.978 & 8.387 & 29.862 & 284 \\
\hline 17A9 & 0.913 & 0.001 & 1.940 & 2.972 & 16.717 & 13.984 & 26.633 & 322 \\
\hline 17B9 & 1.392 & 0.001 & 2.035 & 2.899 & 16.072 & 13.464 & 25.753 & 312 \\
\hline $17 \mathrm{C} 9$ & 1.032 & 0.001 & 2.013 & 2.951 & 16.587 & 13.932 & 26.504 & 313 \\
\hline $17 \mathrm{~A} 10$ & 0.542 & 0.001 & 2.066 & 3.027 & 16.196 & 13.833 & 26.518 & 316 \\
\hline $17 \mathrm{~B} 10$ & 0.894 & 0.001 & 2.143 & 3.145 & 16.388 & 13.955 & 26.850 & 320 \\
\hline $17 \mathrm{C} 10$ & 1.052 & 0.001 & 2.216 & 3.185 & 16.601 & 14.076 & 27.239 & 325 \\
\hline
\end{tabular}


TABLE VIII

GC DATA CONT.

\begin{tabular}{|c|c|c|c|c|c|c|c|c|}
\hline ID & Acetaldehyde & Methanol & $\begin{array}{c}\text { Ethyl } \\
\text { Acetate } \\
\end{array}$ & $\begin{array}{c}\text { n-Propyl } \\
\text { Alcohol } \\
\end{array}$ & $\begin{array}{c}\text { Isobutyl } \\
\text { Alcohol } \\
\end{array}$ & $\begin{array}{c}\text { Isoamyl } \\
\text { Alcohol \#1 } \\
\end{array}$ & $\begin{array}{c}\text { Isoamyl } \\
\text { Alcohol \#2 } \\
\end{array}$ & $\begin{array}{c}\text { Total Fusel } \\
\text { Oils @ 100 } \\
\text { proof } \\
\end{array}$ \\
\hline $18 \mathrm{~A} 9$ & 1.210 & 0.001 & 1.718 & 2.180 & 13.452 & 11.147 & 32.746 & 327 \\
\hline $18 \mathrm{~B} 9$ & 0.840 & 0.001 & 1.835 & 2.217 & 13.483 & 11.352 & 32.744 & 331 \\
\hline $18 \mathrm{C} 9$ & 1.098 & 0.001 & 1.742 & 2.228 & 13.517 & 10.857 & 32.613 & 328 \\
\hline $18 \mathrm{~A} 10$ & 1.630 & 0.000 & 1.905 & 2.543 & 13.537 & 10.662 & 31.436 & 322 \\
\hline $18 \mathrm{~B} 10$ & 1.436 & 0.001 & 1.974 & 2.385 & 13.951 & 11.098 & 32.680 & 332 \\
\hline $18 \mathrm{C} 10$ & 1.601 & 0.001 & 1.990 & 2.363 & 13.807 & 10.922 & 31.981 & 327 \\
\hline $18 \mathrm{~A} 11$ & 1.483 & 0.001 & 1.666 & 1.956 & 13.056 & 10.606 & 32.193 & 326 \\
\hline 18B11 & 0.843 & 0.000 & 1.616 & 1.825 & 12.360 & 10.024 & 31.087 & 311 \\
\hline $18 \mathrm{C} 11$ & 1.065 & 0.000 & 1.540 & 1.700 & 11.955 & 9.555 & 30.196 & 301 \\
\hline 19A9 & 2.247 & 0.004 & 1.948 & 3.244 & 20.752 & 15.747 & 29.688 & 367 \\
\hline 19B9 & 1.278 & 0.001 & 1.790 & 2.971 & 19.771 & 15.056 & 28.126 & 344 \\
\hline $19 \mathrm{C} 9$ & 2.182 & 0.001 & 1.848 & 3.077 & 19.887 & 15.100 & 28.206 & 346 \\
\hline 19A10 & 2.127 & 0.001 & 1.996 & 3.186 & 19.633 & 14.472 & 26.954 & 330 \\
\hline 19B10 & 1.803 & 0.001 & 1.959 & 3.203 & 19.793 & 14.568 & 27.153 & 329 \\
\hline $19 \mathrm{C} 10$ & 1.786 & 0.001 & 2.007 & 3.220 & 20.109 & 14.805 & 27.675 & 341 \\
\hline $20 \mathrm{~A} 9$ & 1.496 & 0.001 & 1.820 & 2.017 & 11.775 & 9.986 & 32.679 & 316 \\
\hline 20B9 & 1.375 & 0.000 & 1.622 & 1.825 & 10.616 & 8.970 & 29.419 & 285 \\
\hline $20 \mathrm{C} 9$ & 0.473 & 0.000 & 1.689 & 1.780 & 10.823 & 8.955 & 29.522 & 286 \\
\hline $20 \mathrm{~A} 10$ & 0.720 & 0.000 & 1.889 & 2.513 & 13.124 & 10.726 & 30.574 & 316 \\
\hline 20B10 & 0.661 & 0.000 & 1.890 & 2.520 & 14.058 & 11.188 & 31.422 & 328 \\
\hline $20 \mathrm{C} 10$ & 1.169 & 0.001 & 2.120 & 2.777 & 14.265 & 11.786 & 32.236 & 337 \\
\hline $20 \mathrm{~A} 11$ & 1.302 & 0.000 & 1.734 & 1.921 & 11.842 & 9.494 & 30.543 & 301 \\
\hline 20B11 & 0.909 & 0.000 & 1.620 & 2.017 & 12.434 & 9.961 & 31.547 & 316 \\
\hline $20 \mathrm{C} 11$ & 0.727 & 0.001 & 0.888 & 1.626 & 9.968 & 8.010 & 25.703 & 257 \\
\hline $21 \mathrm{~A} 9$ & 0.000 & 0.000 & 1.577 & 1.919 & 12.556 & 9.527 & 32.960 & 310 \\
\hline $21 \mathrm{~B} 9$ & 0.580 & 0.000 & 1.696 & 1.970 & 12.666 & 9.759 & 32.828 & 310 \\
\hline $21 \mathrm{C} 9$ & 0.000 & 0.000 & 1.713 & 2.057 & 13.030 & 10.082 & 33.493 & 319 \\
\hline $21 \mathrm{~A} 10$ & 0.000 & 0.000 & 1.847 & 2.576 & 17.415 & 13.863 & 27.464 & 330 \\
\hline $21 \mathrm{~B} 10$ & 0.000 & 0.000 & 1.740 & 2.503 & 16.863 & 13.439 & 26.549 & 319 \\
\hline $21 \mathrm{C} 10$ & 0.551 & 0.000 & 1.794 & 2.532 & 17.315 & 13.803 & 26.942 & 329 \\
\hline $21 \mathrm{~A} 11$ & 0.660 & 0.001 & 1.698 & 2.088 & 13.449 & 10.904 & 33.105 & 331 \\
\hline 21B11 & 0.782 & 0.000 & 1.614 & 1.977 & 13.048 & 10.619 & 32.644 & 325 \\
\hline $21 \mathrm{C} 11$ & 0.475 & 0.001 & 1.615 & 1.949 & 12.875 & 10.379 & 32.096 & 334 \\
\hline $22 \mathrm{~A} 9$ & 0.000 & 0.001 & 1.913 & 2.819 & 17.486 & 13.822 & 27.861 & 330 \\
\hline $22 \mathrm{~B} 9$ & 0.304 & 0.000 & 2.012 & 2.769 & 17.343 & 13.751 & 27.406 & 326 \\
\hline $22 \mathrm{C} 9$ & 0.000 & 0.001 & 1.832 & 2.659 & 16.876 & 13.252 & 26.354 & 313 \\
\hline $22 \mathrm{~A} 10$ & 0.855 & 0.000 & 2.057 & 2.732 & 17.152 & 12.698 & 25.800 & 318 \\
\hline $22 \mathrm{~B} 10$ & 0.912 & 0.000 & 2.529 & 3.404 & 22.052 & 16.245 & 33.107 & 408 \\
\hline $22 \mathrm{C} 10$ & 0.834 & 0.000 & 2.094 & 2.718 & 17.482 & 12.913 & 26.205 & 323 \\
\hline $22 \mathrm{~A} 11$ & 0.427 & 0.000 & 1.804 & 2.504 & 15.926 & 12.605 & 25.546 & 304 \\
\hline 22B11 & 0.000 & 0.000 & 1.959 & 2.600 & 16.517 & 13.108 & 26.599 & 318 \\
\hline $22 \mathrm{C} 11$ & 0.000 & 0.000 & 1.787 & 2.484 & 15.931 & 12.578 & 25.357 & 302 \\
\hline
\end{tabular}


APPENDIX D

CONVERSION DATA

TABLE IX

CONVERSION OF STARCH IN CLEAN FERMENTATIONS

\begin{tabular}{|c|c|c|c|c|}
\hline $\begin{array}{c}\text { Corn } \\
\text { Type }\end{array}$ & Strain & $\begin{array}{c}\text { Potential } \mathrm{CO}_{2} \text { Loss } \\
(\mathrm{g} / 100 \mathrm{~g} \text { corn })\end{array}$ & $\begin{array}{c}\text { Actual } \mathrm{CO}_{2} \text { Loss } \\
(\mathrm{g} / 100 \mathrm{~g} \text { corn })\end{array}$ & $\begin{array}{c}\text { Conversion of } \\
\text { Starch to Sugar }\end{array}$ \\
\hline \hline HTF & All & 38.58 & 36.12 & $93.7 \%$ \\
\hline & $35 \mathrm{D} 28$ & 38.40 & 36.19 & $94.2 \%$ \\
\hline & $35 \mathrm{Y} 33$ & 38.10 & 36.48 & $95.8 \%$ \\
\hline & $32 \mathrm{~K} 22$ & 38.50 & 37.57 & $97.6 \%$ \\
\hline & $34 \mathrm{P} 88$ & 38.40 & 36.70 & $95.6 \%$ \\
\hline & $33 \mathrm{~A} 84$ & 38.70 & 36.55 & $94.4 \%$ \\
\hline & $34 \mathrm{H} 31$ & 38.50 & 36.23 & $94.1 \%$ \\
\hline & $31 \mathrm{G} 66$ & 38.70 & 34.30 & $88.6 \%$ \\
\hline & $33 \mathrm{~N} 54$ & 38.90 & 34.31 & $88.2 \%$ \\
\hline & $34 \mathrm{~A} 15$ & 38.90 & 36.16 & $92.9 \%$ \\
\hline Control & All & 38.55 & 35.78 & $92.8 \%$ \\
\hline & $33 \mathrm{~N} 09$ & 38.40 & 36.21 & $94.3 \%$ \\
\hline & $33 \mathrm{M} 54$ & 38.20 & 33.04 & $86.5 \%$ \\
\hline & $34 \mathrm{D} 71$ & 38.60 & 35.96 & $93.2 \%$ \\
\hline
\end{tabular}

TABLE X

CONVERSION OF SUGAR IN CLEAN FERMENTATIONS

\begin{tabular}{|c|c|c|c|c|}
\hline $\begin{array}{c}\text { Corn } \\
\text { Type }\end{array}$ & Strain & $\begin{array}{c}\text { Set } \\
\text { Balling } \\
(\%)\end{array}$ & $\begin{array}{c}\text { Drop } \\
\text { Balling } \\
(\%)\end{array}$ & $\begin{array}{c}\text { Conversion of } \\
\text { Sugar to EtOH }\end{array}$ \\
\hline \hline HTF & All & 18.6 & 0.9 & $95.4 \%$ \\
\hline & $35 \mathrm{D} 28$ & 19.5 & 1.0 & $95.1 \%$ \\
\hline & $35 \mathrm{Y} 33$ & 18.6 & 0.9 & $95.2 \%$ \\
\hline & 32K22 & 17.7 & 0.3 & $98.3 \%$ \\
\hline & 34P88 & 18.5 & 1.6 & $91.5 \%$ \\
\hline & 33A84 & 18.6 & 1.5 & $92.2 \%$ \\
\hline & 34H31 & 18.3 & 0.5 & $97.5 \%$ \\
\hline & 31G66 & 17.1 & 0.3 & $98.2 \%$ \\
\hline & 33N54 & 19.1 & 0.9 & $95.5 \%$ \\
\hline & 34A15 & 19.4 & 0.6 & $96.9 \%$ \\
\hline Control & All & 18.6 & 0.9 & $95.4 \%$ \\
\hline & 33N09 & 19.1 & 0.9 & $95.3 \%$ \\
\hline & 33M54 & 16.8 & 0.7 & $95.8 \%$ \\
\hline & 34D71 & 18.7 & 0.9 & $95.3 \%$ \\
\hline
\end{tabular}




\section{APPENDIX E}

\section{STATISTICAL ANALYSIS}

\section{TABLE XI}

STATISTICAL ANALYSIS OF ALL FERMENTATIONS

\begin{tabular}{|c|c|c|c|c|c|}
\hline \multirow{7}{*}{ Overall } & & $\begin{array}{c}\text { Average } \\
\text { ABV } \\
(\%)\end{array}$ & Std Dev & Variance & $\begin{array}{c}99 \% \\
\text { Confidence } \\
\text { Level }\end{array}$ \\
\hline & All & 9.244 & 0.3900 & 0.1521 & 0.0680 \\
\cline { 2 - 6 } & Control & 9.116 & 0.3140 & 0.0986 & 0.0644 \\
\cline { 2 - 6 } & HTF & 9.579 & 0.3727 & 0.1389 & 0.1239 \\
\hline \multirow{2}{*}{ Clean } & Control & 9.339 & 0.2019 & 0.0408 & 0.0812 \\
\cline { 2 - 6 } & HTF & 9.687 & 0.3692 & 0.1363 & 0.1434 \\
\hline \multirow{2}{*}{ Contaminated } & Control & 9.038 & 0.3095 & 0.0939 & 0.0737 \\
\cline { 2 - 6 } & HTF & 9.284 & 0.1708 & 0.0292 & 0.1100 \\
\hline
\end{tabular}


Kara Zoeller was raised in Elizabethtown, KY and graduated from the University of Louisville with a B.S. in Chemical Engineering in May 2008. She performed all three of her semesters of co-op at Brown-Forman in Louisville, KY. She will receive her Master's degree in Chemical Engineering in May 2009 from the University of Louisville. 